\title{
Haemodynamics during haemodialysis
}

Citation for published version (APA):

Leunissen, K. M. L. (1988). Haemodynamics during haemodialysis. [Doctoral Thesis, Maastricht

University]. Rijksuniversiteit Limburg. https://doi.org/10.26481/dis.19881209kl

Document status and date:

Published: 01/01/1988

DOI:

$10.26481 /$ dis. $19881209 \mathrm{kl}$

Document Version:

Publisher's PDF, also known as Version of record

\section{Please check the document version of this publication:}

- A submitted manuscript is the version of the article upon submission and before peer-review. There can be important differences between the submitted version and the official published version of record.

People interested in the research are advised to contact the author for the final version of the publication, or visit the DOI to the publisher's website.

- The final author version and the galley proof are versions of the publication after peer review.

- The final published version features the final layout of the paper including the volume, issue and page numbers.

Link to publication

\footnotetext{
General rights rights.

- You may freely distribute the URL identifying the publication in the public portal. please follow below link for the End User Agreement:

www.umlib.nl/taverne-license

Take down policy

If you believe that this document breaches copyright please contact us at:

repository@maastrichtuniversity.nl

providing details and we will investigate your claim.
}

Copyright and moral rights for the publications made accessible in the public portal are retained by the authors and/or other copyright owners and it is a condition of accessing publications that users recognise and abide by the legal requirements associated with these

- Users may download and print one copy of any publication from the public portal for the purpose of private study or research.

- You may not further distribute the material or use it for any profit-making activity or commercial gain

If the publication is distributed under the terms of Article $25 \mathrm{fa}$ of the Dutch Copyright Act, indicated by the "Taverne" license above, 
HAEMODYNAMICS DURING HAEMODIALYSIS 



\section{HAEMODYNAMICS DURING HAEMODIALYSIS}

PROEFSCHRIFT

TER VERKRIJGING VAN DE GRAAD VAN DOCTOR AAN DE RIJKSUNIVERSITEIT LIMBURG TE MAASTRICHT, OP GEZAG VAN DE RECTOR MAGNIFICUS, PROF.DR. F.I.M. BONKE. VOLGENS HET BESLUIT VAN HET COLLEGE VAN DEKANEN, IN HET OPENBAAR TE VERDEDIGEN OP VRIJDAG, 9 DECEMBER 1988 TE 14.(0) UUR

DOOR

KAREL MARIA LUCAS LEUNISSEN

GEBOREN TE HEERLEN, 9 FEBRUARI 1954 
PROMOTOR:

Prof.dr. J.A. Flendrig

CO-PROMOTOR:

Dr. J.P. Van Hooff

BEOORDELINGSCOMMISSIE:

Prof.dr. M. Allessie

Prof.dr. S. Shaldon, Nimes, Frankrijk

Dr. A.W. Mulder, Eindhoven

Dr. D.W. Slaaf

Prof.dr. H.A.J. Struyker Boudier

Het onderzoek, in dit proefschrift werd financieel mogelijk gemaakt door steun van de Nierstichting Nederland, tevens was er materiële en financiële ondersteuning van de firma's: Gambro BV. Fresenius BV, Hospal BV, Organon BV, Belcon bv, HSH Medical Supplies.

De omslag werd gemaakt door dhr. Bedaux, nierpatiënt en kunstzinnig therapeut, die een impressie gaf van een bloedrukdaling tijdens dialyse, zoals die door een patient ervaren wordt. 
Ter nagedachtenis aan mijn vader Aan mijn moeder

Voor Tiny, Martijn en Jeroen 



\section{CONTENTS}

\section{Chapter I:}

Intraduction.

\section{Chapter II:}

Echography of vena cava inferior is a simple and reliable tool for estimation of dry weight in haemodialysis patients.

\section{Chapter III:}

Plasma alpha-human atrial natriuretic peptide and dry weight in chronic haemodialysis.

\section{Chapter IV:}

The influence of fluid removal during haemodialysis on macro- and skin microcirculation.

\section{Chapter V:}

Acetate versus bicarbonate haemodialysis in critically ill patients. 55

\section{Chapter VI:}

Influence of left ventricular function on changes in plasma volume during acetate and bicarbonate dialysis.

\section{Chapter VII:}

Ionized plasma calcium plays a pivotal role in controlling blood pressure during haemodialysis.

\section{Chapter VIII:}

Summary and conclusions.

Samenvatting

Nawoord 



\section{Historical review}

The first reported method for cleansing blood was bloodletting. Papyrus writings mention that bloodletting or venesection was common practice in ancient Egypt.

Hippocrates $(460-377$ B.C.), who popularized bloodletting, wrote that "venesection holds the first place in conducting the treatment.." of a long list of diseases.

Celsus 153 B.C. - 7 A.D.) regarded bloodletting as the chief way to extract toxic waste from the body.

Another means of removing wastes from the body is through the skin, the largest organ of the body. It has been recorded that ancient Egyptians built baths for ceremonial cleansing and for curative purposes.

In the Middle Ages the barber surgeon began to practice "medicine" and during this period the philosophy of bloodletting prevailed. Not only venesections were done but also arteries were opened by Antyllus, a Byzantine surgeon. Everybady firmly believed in the efficacy of bloodletting.

In the Renaissance in the 14-16th centuries phlebotomy was still highly acclaimed as an essential remedy and because the "medicina astrologica" was getting more important, a regimen for venesection was devised, based on a star map. Every vein known in the body was said to correspond to a star or planet, just as various body organs corresponded to signs of the zodiac. There were 53 venesection locations that could be bled, with each point related to four, five or more disorders. In this period some physicians disapproved venesection and its insane waste of blood, often leading to death of the patient.

Medical knowledge advanced rapidly during the 19 th century. Physicians recognized the need to purify the blood without draining it. However, bloodletting was still practiced. Also leeching became popular.

Later on scientists began to realize that only certain elements in the blood were harmful and needed to be removed. In 1913, Abe1, Rowntree and Turner postulated the use of external dialysis of blood. They extracted salicylate from the blood of two dogs by dialysis. 
In 1928 the first successful haemodialysis procedure on a human being, using a colloidin membrane, was conducted by Georg haas in Gieszen. This was possible in providing coagulation by the use of a new anticoagulant: heparin, introduced for this purpose by vecheles.

The definite break through of haemodialysis was made by $H$. Kolff in Kampen, the Netherlands, who, togheter with the engineer $H$. Berk, constructed a rotating drum dialyzer in which the blood was propelled by rotation through 40 meters of cellophane tubing. He reported the first surviver of acute renal failure in 1945.

Continuing this pioneering work, skeggs and Leonards in 1948 designed the original plate dialyzer, including the Kiil dialyzer, consisting of sheets of cellophane compressed between grooved plates, through which the dialysate fluid and blood flow in opposite directions.

Long term dialysis for chronic cases was made possible in 1960 with the development of dependable long term cannulas, made of Teflon and Silicone rubber, the first of which was the scribner shunt. Arteriovenous shunts have also improved access to the blood stream and are mostly used today. 
In the last 30 years development of modern clinical technology has made it possible to treat patients with end stage renal failure with an artificial kidney. The function of the kidneys ie correction of electrolyte and water balance, and excretion of waste products of metabolism is replaced by cleansing of the blood by haemodialysis. Today haemodialysis is usually performed three times a week during 3-4 hours. This intermittent treatment is in sharp contrast with the continuous function of the kidney. During 3-4 hours of haemodialysis excessive volume and waste products have to be removed. Furthermore the acidosis and electrolyte balance have to be corrected. These rapid changes of the "milieu interieur" might lead to haemodynamic instability during and after haemodialysis [1-3]. A steep drop of blood pressure is very unpleasant and potentially endangers the patient. Furthermore, hypotension makes haemodialysis inefficient.

So as in ancient times with blood letting also modern dialysis therapy is still complicated by haemodynamic instability.

The occurrence of haemodynamic instability has been attributed to various factors: I) volume status [4]. II) buffer substrate of the dialysate [5], III) cardiovascular status [6], and IV) composition of the dialysate [7].

The aim of this thesis was to investigate during haemodialysis the influence of these factors on circulation. The study was performed within the clinical cardiovascular research unit of the university of Maastricht. With the development of various techniques applicable to man, it became possible to study haemodynamics in patients during treatment with haemodialysis.

\section{Optimal dry weight:}

Patients with end stage renal disease have an impaired volume regulation. Excessive volume has to be removed during dialysis. Estimation of this volume depends on estimation of the optimal dry weight. Therefore determination of an optimal dry weight is very important. An incorrectly estimated dry weight is either leading to chronic fluid overload or chronic underhydration.

Dry weight for a given patient is frequently defined as the weight obtained at the conclusion of a regular dialysis treatment below which 
the patient more often than not will become symptomatic and go into shock [1].

Dry welght is difficult to measure in the dialysis patient. Because of the ever-present risk of overhydration and associated volume hypertension, body weight, blood pressure and heart rate before, during and after each dialysis are always measured, aiming at control of blood pressure by ultrafiltration and avoldance of hyper- and hypotension [8]. However, hypertension is not always associated with volume overload, and hypotension can be caused by other factors than hypovolaemia. Invasive measurement of central venous pressure, together with measurement of total blood volume and extracellular volume, could give adequate information about fluid status. However, these invasive techniques are not suitable for routine clinical practice. The use of chest $X$-ray parameters, ie redistribution and vascular pedicle width, have been advocated as indicator of fluid status [9]. The effectiveness of this method could not be confirmed by others [10]. So assessment of optimal dry weight is mainly based on "clinical acumen" [11]. A more accurate and objective assessment of optimal dry weight is therefore mandatory.

\section{a) Echography}

Moreno et al investigated in vitro the pressure cross-sectional area relationship of a long segment of the vena cava inferior of a dog, by introducing into of removing from the lumen of the vessel a fixed volume of fluid, while recording the pressure. They found, that when venous pressures amounted between -2 to $5 \mathrm{mmHg}$, there was an almost linear steep increase of the cross sectional area and anteriorposterior diameter of the vena cava inferior. Above $5 \mathrm{mmHg}$ the distensibility of the vein was decreasing, suggesting that the maximal anatomical width was reached $[12]$.

In patients with right sided cardiac disease there was a significant correlation between the anterior-posterior diameter of the vena cava inferior and the degree of collapse at deep inspiration, as measured just below the diaphragm, and invasively measured central venous pressure [13]. In man vena cava inferior can be easily visualized with the help of echography. Echography of the vena cava inferior might therefore be of use for determination of volume status of a dialysis patient. 
b) Atrial natriuretic peptide

It has been shown that an increase of extracellular volume is leading to an increase of serum alpha-human-atrial natriuretic peptide (alpha-h-ANP) [14-15]. Therefore levels of serum alpha-h-ANP might give an indication for the estimation of optimal dry weight. During ultrafiltration as well as haemodialysis alpha-h-ANP decreases significantly. Alpha-h-ANP was not found in significant amounts in the dialysate. So the decrease of alpha-h-ANP was related to the decrease of extracellular volume [16]. However, after ultrafiltration to optimal dry weight, determined on clinical grounds, alpha-h-ANP levels still remained elevated above normal levels and varied widely [16]. One of the explanations for the latter findings might be, that optimal dry weight was not correctly estimated. This explanation is very likely, because the estimation of an optimal dry weight has been done so far on clinical grounds.

If the vena cava inferior diameter and his collapsibility index (VCI indices) are giving a good indication for fluid status, there should be during dialysis with fluid removal a significant correlation between VCI indices and changes of alpha-h-ANP levels, and after dialysis a less wide variation of alpha-h-ANP levels.

c) Macro- and microcirculation during dialysis in relation to the optimal dry weight

Haemodialysis with fluid removal might lead to various changes of the macrocirculation. The nature of these changes will probably depend on fluid status of the patient. It is unknown to which extent microcirculatory changes might occur as well. It can be hypothised that changes of microcirculation depend on changes of macrocirculation and local autoregulatory effects as well.

It is unknown to which extent catecholamines are of importance for the interaction between macro- and microcirculation [17]. During dialysis catecholamines are removed [18]. However, their pharmacological effects depend on the increase of serum ionized calcium [19].

Nowadays various noninvasive methods are available for studying macrocirculation such as continuous wave Doppler [20] as well as microcirculation such as laser Doppler [21] and intravital microscopy [22-23]. With the help of these methods effects of changes of extracellular fluid volume during haemodialysis on macro- and 
The purpose of this thesis was to investigate the following questions:

1. Is echography of vena cava inferior a reliable method for determining optimal dry weight?

2. Does measurement of serum alpha-h-ANP levels give information about the volume status of the patient?

3. What is the relationship between the changes of macrocirculation and changes of microcirculation during haemodialysis?

4. What is the effect of type of buffer substrate on hamodynamic stability in critically ill patients?

5. What is the effect of type of buffer substrate on haemodynamic stability in patients with impaired left ventricular function?

6. What is the influence of bicarbonate concentration of the dialysate on haemodynamic stability? 
1. Henderson LW. Symptomatic hypotension during haemodialysis. Kidney Int 17: 571-576 (1980).

2. Bergström J, Asaba H, Furst P, Oules R. Dialysis ultrafiltration and blood pressure. Proc Eur Dial Transpl Assoc 13: 293 (1976).

3. Kjellstrand $C M$, Rosa $A A$, skideman JR. Hypotension during haemodialysis: osmolality fall is an important pathogenic factor. ASATO Journal 3: 11-19 (1980).

4. Leunissen KML, Cheriex EC, Janssen JHA, Mooy JMV, Van Hooff JP. The inferior vena cava diameter and collapsibility index and the optimal dry weight in chronic haemodialysis patients. Nephrol Dial Transp1 2: $438(1987)$.

5. Aizawa $Y$, Ohimori $T$, Imai $K$, Nara $Y$, Matsuoka M, Hirasawa $Y$. Depressant action of acetate upon the human cardiovascular system. Clin Nephrol 8: 477-480 (1977).

6. Ruder MA, Alpert MA, Van Stone JA et al. Comparative effects of acetate and bicarbonate haemodialysis on left ventricular function. Kidney Int 27: 768-773 (1985).

7. Baldamus CA, Ernst $w$, Frei $u$, Koch KM. Sympathetic and haemodynamic response to volume removal during different forms of renal replacement therapy. Nephron 31: 324-332 (1982).

B. Kinet JP, Soyeur D, Balland N, Saint-Reny M, Collignon P, Godon JP. Hemodynamic study of hypotension during hemodialysis. Kidney Int 21: 868-876 (1982).

9. Milne ENC, Pistolezi M, Miniati M, Giuntini $C$. The vascular pedicle of the heart and the vena azygos (part I and II). Radiology 152:1-17 (1984).

10. Janssen JHA, Van Engelshoven JA, Cheriex EC, Leunissen KML. Chest $x$-ray in patients on chronic hemodialysis: has it any value? Radiologica: c/o Sociedade Portuguesa de Radiologia e Medicina Nuclear (in press).

11. Keshaviah PR, Shaldon $S$. Hemodialysis monitors and monitoring. In: Replacement of renal function by dialysis. Ed. W. Drukker, Second Edition: Martinus Nijhoff Publishers Boston (1983).

12. Moreno AH, Katz AI, Gold LD, Reddy RV, mechanics of dystension of dog veins and other very thin-walled tubular structures. Circ Res 27:11069 (1970). 
13. Moreno FLL, Hagan AD, Holmen JR, Pryor TA, Strickland RD, Castle CH. Evaluation of size and dynamics of the inferior vena cava as an index of right-sided cardiac function. Am J Cardiol 53: 579-585 $(1984)$.

14. Wilkins JR, Wood JA, Adu D, Lote CJ, Kenda11 MJ, Michael J. Change in plasma immunoreactive atrial natriuretic peptide during sequential ultraflitration and hemodialysis. Clin science 71 : $157-160(1986)$.

15. Rasher $W$, Tulassay $T$, Lang RE. Atrial natriuretic peptide in plasma of volume overloaded children with chronic renal failure. Lancet if: 303-305 (1985).

16. Canella G, Rodella A, Brunori M, Maiorca R. Plasma concentrations of atrial natriuretic peptide in relation to body fluid status in chronic uraemia. Nephrol Dial Transp1 2: 158-160 (1987).

17. Shaldon $\mathrm{S}$, Baldamus $\mathrm{CA}$, Koch $\mathrm{KM}$, Lysaght $\mathrm{MJ}$. of sodium, symptomatology and syilogism. Blood Purif I: 16-24 (1983).

18. Zacchelli P. Catizone L, Degli Esposti E, Fusaroli M, Ligabue A, Zuccala $A$. Influence of ultrafiltration on plasma renin activity and adrenergic system. Nephron 21: 317-324 (1978).

19. Khalil $R$, Lodge $\mathbb{N}$, Saida $K$, Van Breemen $C$. Mechanisms of calcium activation in vascular smooth muscle. J Hypert 5: S5-S15 (1987).

20. Chandraratna PA, Marima M, MCKay CH, Nimalasuriya A, Swinney R, Elkayam U, Rahimtoola SH. Determination of cardiac output by transcutaneous wave ultrasonic doppler computer. Am J Cardiol 53: $234-237(1984)$.

21. Tenland $T$. On laser doppler flow metry methods and intravascular application. Thesis, Linköping (1982).

22. Bollinger A, Butti PO, Barras JP, Trachsler $H$, Siegenthaler $W$. Red blood cell velocity in nailfold capillaries of men measured by a television microscope technique. Microvasc Res 7:61-72 (1974).

23. Jacobs MJHM. Capillary microscopy and haemorrheology in vasospastic and occlusive vascular diseases. Thesis, Maastricht $(1985)$.

24. Merrill JP, Thorn GW, Walter $\mathrm{CW}$. The use of an optimal kidney I technique. J $\mathrm{Cl}$ in Invest 29: 412-424 (1950).

25. Mion CM, Hegstrom RM, Boen ST, Scribner BH. Substitution of sodium acetate for sodium bicarbonate in the bath fluid for hemodialysis. Trans Amer Soc Artif Intern Organs 10: 110-113 (1964). 
26. Tolchin N, Roberts JC, Lewis EJ. Respiratory gas exchange by high efficiency hemodialysis. Nephron 21: 137-145 (1978).

27. Aurigemma NM, Feldman NT, Gottlieb M, Ingram RH, Lazarus JM, Lowie EG. Arterial oxygenation during hemodialysis. N Engl J Med 297: $871-873(1977)$.

28. Ischi $K$, Onoyama $K$, Maeda $T$ et al. Comparison of hemodynamics induced by conventional acetate hemodialysis, bicarbonate hemodialysis and ultrafiltration. Clin Nephrol 14: 294-298 (1980).

29. Mansell MA, Crowther A, Laker MF, wing AJ. The effect of hyperacetataemia on cardiac output during regular hemodialysis. Clin Nephrol 18: 130-134 (1982).

30. Liang CS, Lowenstein JM. Metabolic control of circulation. Effects of acetate and pyruvate. $\mathrm{J} \mathrm{Cl}$ in Invest $62:$ 1029-1038 (1978).

31. Kirkendol PL, Pearson JE, Bower JE, Holbert RD. Myacardial depressant effects of sodium acetate. Cardiovasc Res 12: 127-136 (1978).

32. Cannella G, Maccagnola V, Guilani B, Maiorca R, Draghin E. The oxyhemoglobin dissociation curve during acetate and bicarbonate dialysis. Nephron 32: 378 (1982).

33. Mestrangolo $F$, Rizreli $S$, Corliano $C$ et al. Benefits of bicarbonate dialysis. Kidney Int 28: S188-S193 (1985).

34. Hakim RM, Pontrer MA, Tilton D, Lazarus JM, Gottlieb MN. Effects of acetate and bicarbonate dialysate in stable chronic dialysis patients. Kidney Int 28:535-540 (1985).

35. Van stone JC, cook J. The effect of bicarbonate dialysate in stable chronic hemodialysis patients. Dial Transpl 8: 703-709 (1979).

36. Hampl $H$, Schafer GE, Kessel M. Hemodynamic state in severe chronic renal failure. Pathophysiological aspects of cardiovascular function and the importance of bicarbonate dialysis. Nephron 39: $102-111(1985)$.

37. Leunissen KMl, Hoorntje SJ, Fiers HA, Dekkers WT, Mulder Aw. Acetate versus bicarbonate hemodialysis in critically ill patients. Nephron 42: 146-151 (1986).

38. Hsu $\mathrm{CH}$, Swartz RD, Somermeyer MG, Raj A. Bicarbonate hemodialysis: Influence on plasma refilling and hemodynamic stability. Nephron 38: 202-208 (1984). 
39. Binge1 $M$, Lonnemiann $G$, Koch KM, Dinarello $\mathrm{Ca}$, Shaldon 5 . Enhancement of in vitro human interleukin-I production by sodium acetate. Lancet 1: 14-16 (1987).

40. Henrich WL, Hunt JM, Nixon JV. Increased ionized Calcium and left ventricular contractility during hemodialysis. N Engl I Med 310: $19-23(1984)$.

41. Thode J. Fogh-Anderson $N$, Wimberley PD, $M$ lier-S rensen $A$, Siggaard-Andersen 0 . Relation between $\mathrm{pH}$ and ionized calcium in vitro and in vivo in man. Scand J Clin Lab Invest 43:79-82 (1983).

42. Williamson JR, Safer B, Rich T, Schaffer S, Kobayashi K. Effects of acidosis on myocardial contractility and metabolism. Acta Med Scand 587: $95-112(1975)$. 
CHAPTKR II

ECHOGRAPHY OF THE VENA CAVA INFERTOR IS A SIMPLE AND RELTABLE TOOL FOR ESTIMATION OF "DRY WEIGHT" IN HAEMODIALYSIS PATIENTS

E.C. Cheriex, K.M.L. Leunissen, J.H.A. Janssen, I.M.V. Mooy, J.P. van Hooff

Department of Cardiology and Internal Medicine University Hospital Maastricht, The Netherlands 
Using echography the diameter (VCD) of wena cava inferior (VCI) and its decrease on deep inspiration (collapse index = CI) were evaluated in haemodialysis patients. Linear regression in predicting VCD and CI by measured mean right atrial pressure (MRAP) revealed a $r^{2}$ of 0.72 , p 0.0002 and a $r^{2}$ of 0.85, p<0.0001, respectively. Non-1inear regression analysis in predicting $V C D$ and $C I$ by MRAP revealed a $\eta^{2}$ of $0.90(\mathrm{p} \times 0.0001)$ and $a n^{2}$ of $0.94(\mathrm{p}<0.0001)$ respectively. These results are indicating that the VCI indices can be used as parameter for both high and low filling pressures. Overhydration (MRAP $\geq 8$ mmitg) was defined as a CI of less 40 and $a$ VCD of more than $18 \mathrm{~mm}$, and underhydration (MRAP $\leqslant 3 \mathrm{mmHg}$ ) as a VCD of less than $13 \mathrm{~mm}$ and $\mathrm{CI}$ of above $75 \%$.

In 22 patients in which dry weight was determined on clinical grounds, only 6 had a correct dry weight according to VCI indices. Reliability of VCI indices for estimation of body fluid status was proven by the fact that during haemodialysis with fluid removal. Postdialysis underhydrated patients, according to VCI indices, showed a decrease of mean arterial pressure (MAP) and stroke volume, and an increase of HR. No such changes were observed in postdialysis normovolaemic and hypervolaemic patients according to the vena cava indices. Furthermore, blood volume in normo- and hypervolaemic patients decreased much less than in hypovolaemic patients, notwithstanding the same amount of ultrafiltration.

The relative decrease of VCD correlated significantly $(r=0.79$, p 00.0001$)$ with the relative decrease of tatal blood volume. Furthermore after dialysis there was a significant correlation between VCD and total blood volume $(r=0.54, p<0.02)$. The relationship of VCD with MRAP and blood wolume might be an indication that VCD is pressure and volume related.

\section{Introduction}

Patients with end stage renal disease have an impaired volume regulation. During dialysis excess volume has to be removed. Estimation of excess of volume is dependent on estimation of dry weight. For a given patient dry weight is frequently defined as the 
weight obtained at the conclusion of a regular dialysis treatment below which the patient more often than not will become symptomatic and go into shock. However, symptomatic hypotension is not only related to the amount of ultrafiltrate during haemodialysis treatment, but also the rate at which the removal occurs [1]. An incorrect estimation of dry weight is leading either to chronic fluid overload or chronic underhydration. Estimation of dry weight is frequently based on clinical grounds, and noninwasive parameters as jugular venous pressure, blood pressure profile during ultrafiltration and chest x-ray parameters. Estimation of dry weight with help of these methods is not very reliable [1-3]. A more accurate, objective non-invasive assessment of optimal dry weight is therefore mandatory.

Using echography Natori et al [4] showed that the anteroposterior diameter and the amount of inspiratory decrease of diameter of vena cava inferior (VCI) measured just below the diaphragm in the hepatic segment, in patients lying in supine position, correlated well with central venous pressure.

The basic work was done by Moreno et al. In vitro he investigated the pressure-cross sectional area rellationship of a long segment of the vena cava inferior of a dog by introducing or removing a fixed volume of fluid into or from the lumen of the vessel while recording the pressure. They found that at a venous pressure between -2 and $5 \mathrm{mmHg}$ there was an almost 1 inear steep increase of the cross-sectional area and anterior posterior diameter of the vena cava inferior. Above $5 \mathrm{mmHg}$ the distensibility of the vein decreased, suggesting that the maximal anatomical width was reached [5].

In a study of patients with right sided cardiac disease, Moreno found a significant difference in diameter of the vena cava inferior and the collapsibility index between the group with normal and elevated right atrial pressure [6].

Because echographic investigation of VCI can easily be performed in most patients, its value as a potential tool in guiding optimal fluid balance during haemodialysis was investigated.

\section{Patients and methods}

The relationship between the vena cava diameter, its collapsibility index and the mean right atrial pressure was studied in 13 dialysis 
patients (group I: 7 males and 6 females). It was chosen to look only for correlation in patients on haemodialysis with a good cardiac and valvular function, and without pulmonary disease.

Vaso-active medication was stopped 16 hours before the investigations were pertormed.

Noninvasive measurements using the echography of VCI were correlated wh invasive pressure measurements using a central venous line or Swan Ganz catheter.

Echographic examinations were done by one independent investigation team. Echography of VCI was performed in supine position after 10 minutes of rest. The transducer was placed in the subxiphoidial region and long and short axis views of IVC were obtained just below the diaphragm in the hepatic segment. An M-mode echogram with simultaneous electrocardiographic monitoring was recorded. VCD was measured before the $\mathrm{P}$-wave on the ECG, to avoid interference with $\mathrm{A}$-wave and $\mathrm{V}$-waves on the venous pressure curve (figure 1). In case of atrial fibrillation measurements were made before the onset of the QRS complex.

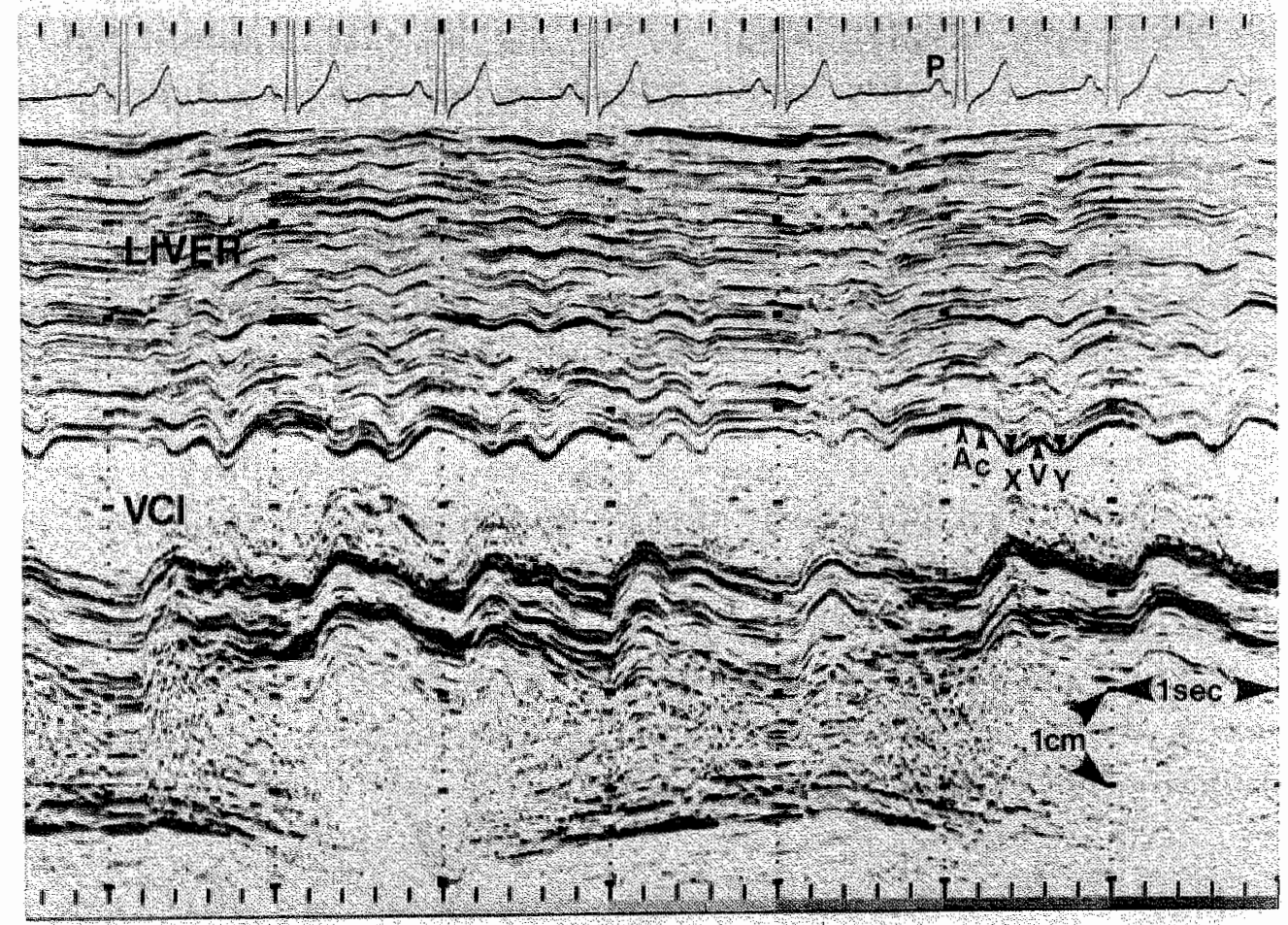

Eigure 1:

The M-mode recording of the vCI shows the normal central venous pressure curve, with the $A, C, X, V, Y$ waves. 
VCD was measured during expiration and maximal inspiration avoiding valsalva-1ike manoeuvers (figure 2). CI was defined as (Imaximal diameter on expiration - minimal diameter on deep inspiration / maximal diameter on expirationl $x$ 100. The inter- and intraobserver variability for our cardiovascular research laboratory was for the vCD less than 5\% and $2.5 \%$ respectively, and for the CI less than $10 \%$ and $2.5 \%$ respectively. The interobserver variability of the VCD in the study of Moreno was less than 5\% [6]. VCD and $C I$ could be measured accurately in almost all dialysis patients. In patients with polycystic liver disease vCI is difficult to visualize.

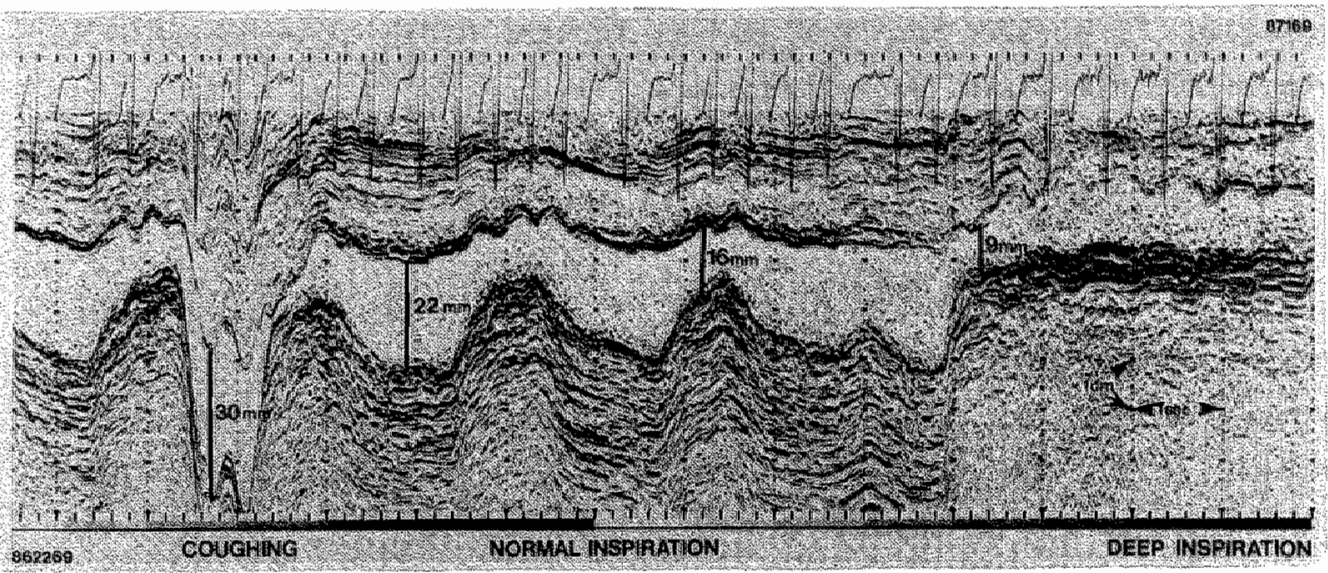

\section{Piqure 2:}

This M-mode recording shows the difference between the collapse index during normal and deep inspiration. Note that optimal collapse index ig registrated the onset of inspiration.

Measurements of VCI were done without mechanical ventilation. Simultaneously with ultrasonographic recording of vCI, right atrial pressure were recorded by means of a central venous or Swan Ganz catheter by another investigation team.

The second part of the study was initiated to establish the relationship between the vena cava diameter, its collapsibility index and total blood volume. The study was performed in a second group of dialysis patients. The patients with cardiac diseases i.e. severe left ventricular dysfunction or valvular disease were excluded from the study as well as patients with pulmonary disease. The effects of 
haemodialysis on VCI indices were studied and the changes of these indices were correlated with changes in ventricular function and total blood volume. It concerned 22 chronic dialysis patients (group II): 12 males and 10 females. The mean body weight was $65.5 \pm 12.4 \mathrm{~kg}$. The mean age was $51.8 \pm 11.2$. All vasoactive medication was stopped 16 hours before the investigations were done.

In group II immediately before and 15 minutes after haemodialysis the following recordings and measurements were made. Stroke vollume, body weight, mean blood pressure, heart rate, ultrafiltration volume, blood volume, VCD and CI.

Cardiovascular investigations were done using $M$-mode and 2-dimensional echocardiography. M-mode echocardiograms were recorded with a paper speed of $25 \mathrm{~mm} / \mathrm{sec}$, using a Hewlett-Packard 77020 AC echocardiograph with a $3.5 \mathrm{MHz}$ phased array transducer.

Data were analysed according to the ASE recommendations [7], using a transducer position perpendicular to the left ventricular long axis [B].

Plasma volume (Pvo) was measured according to the radio-iodinated serum albumin method [9]. From plasma volume before dialysis red blood cel1 volume (RBC) was calculated: $\mathrm{RBC}$ volume $=$ PVo (Hcto/(1 - Hcto). (Hcto=haematocrit at $t=0$ ).

Changes in plasma volume were measured according to the serial haematocrit method [10]. From these changes in total blood volume were measured, assuming that the RBC volume did not change during dialysis. statistical analysis was performed using the student's paired t-test. A p-value of $<0.05$ was considered significant. Results are reported as mean $+/$ - one standard deviation of the mean. The coefficients $r^{2}$ and $m^{2}$ were calculated using linear and curvilinear regression analysis. Furthermore the one way analysis of variance was used (SPPS/PC ${ }^{+}$. Correlation coefficlents were calculated using the Fearson's test.

\section{Results}

The relation between invasive haemodynamic measurements and noninvasive measured VCI indices in group $I$ is shown in figure 3 . Linear regression in predicting CI by MRAP revealed a $\mathrm{r}^{2}$ of 0.85 , while linear regression in predicting $V C D$ by MRAP resulted in a $r^{2}$ of 0.72 $(p<0.0002)$ (figure 3 ). 
- กา 13

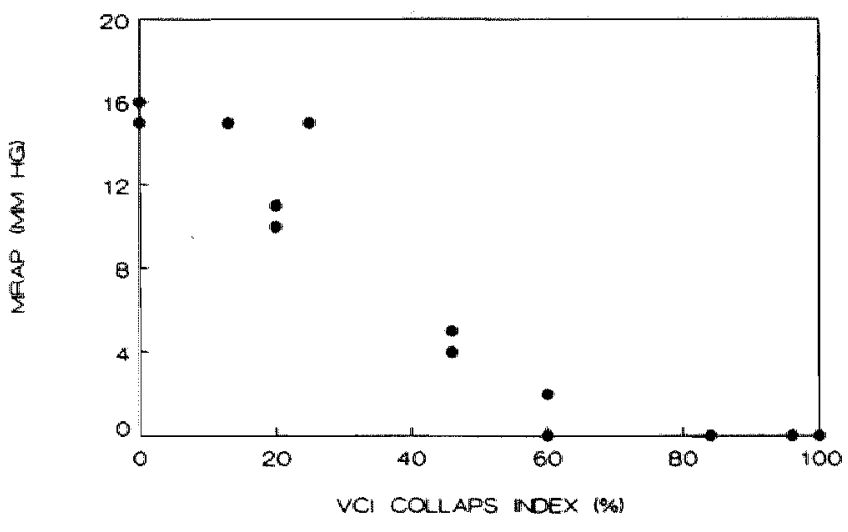

$B$

- $\quad 10=13$

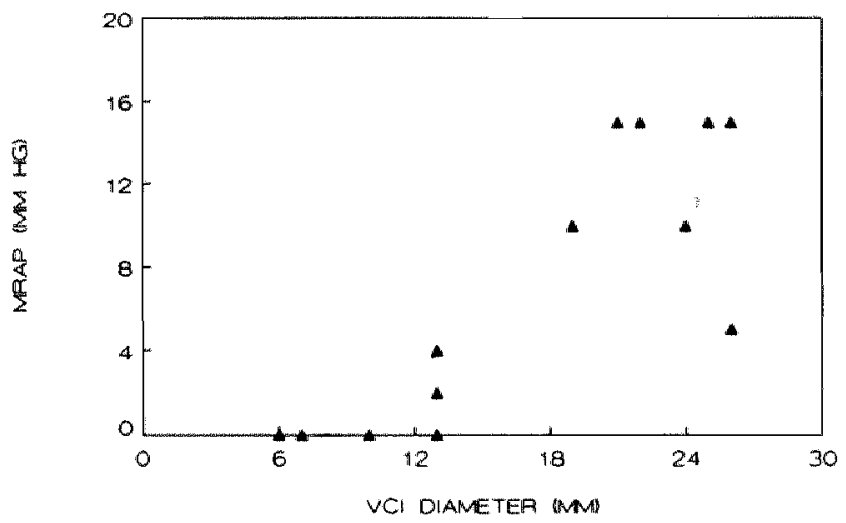

\section{Fiqure 3:}

a. The upper scatterplot shows the relation between the vena cava inferior collapse index and the mean right atrial pressure (MRAP).

b. The lower scatterplot shows the relation between the dianeter of the vena cava inferior (VCI) and the MRAP.

When non-linear regression was applied in predicting CI by MRAP the $n^{2}$ coefficient increased to $0.94(p<0.0001)$. IN the relation between VCD and MRAP non-linear regression resulted in a $\mathrm{m}^{2}$ of 0.90 (p/0.0001), indicating a curvilinear relation. In the one way analysis of variance there was a significant weighted linear term (p<0.001), but also a significant weighted quadratic term $(p<0.05)$ in predicting VCD by MRAP. However, in predicting CI by MRAP only a significant weighted linear term was found $(p<0.0025)$. 


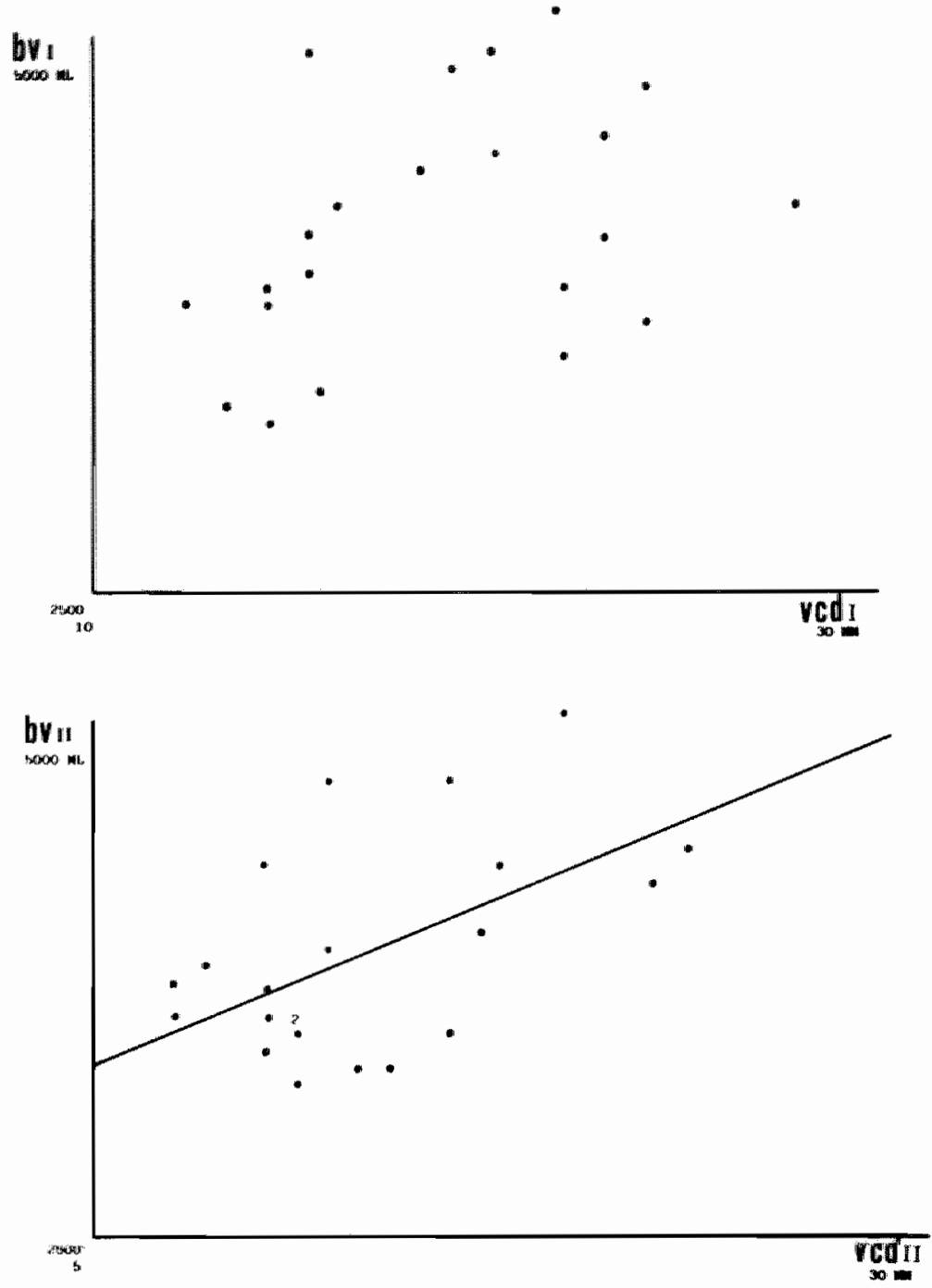

\section{Fiqure 4:}

The upper scatterplot shows the relation between the vena cava inferior diameter and the total blood volume before dialysis $\left(B V_{I}\right)$, and the lower scatterplot the relation between the vena cava inferior diameter and the total blood volume after dialysis (BV II).

These results indicate that $V C D$ and/or $C I$ can be used as a parameter for both high ( $\geq 8 \mathrm{mmHg}$ ) and low filling pressures ( $\leq 3 \mathrm{mmHg}$ ) in dialysis patients.

In group II before dialysis no significant correlation was found between VCD, $C I$ and blood volume $(r=0.36, p=0.21 ; \quad r=-0.13, p=0.56$ respectively). After dialysis still no correlation was found between CI and blood volume $(r=-0.35, p=0.25)$. However, a significant correlation was found between VCD and blood volume $(r=0.54 ;$ pro.02) (figure 4). 
Percentual changes of VCD and total blood volume were significantly correllated as well ( $r=0.79, p<0.0001)$.

After dialysis patients of group II were divided according to vena cava indices: 13 patients were considered underhydrated (VCD $16.2 \rightarrow 10.0$; CI $61.0 \rightarrow 76.81,6$ patients normovolaemic (VCD $21 \rightarrow 15 ;$ CI $60.5 \rightarrow$ $73.0)$ and 3 still hypervolaemic (WCD $23.7 \rightarrow 22,3 ;$ CI $32 \rightarrow 40$ ). In these postdialysis underhydrated patients blood volume decreased significantly with $10.7 \pm 5.4 \frac{8}{5}(p<0,0001)$. This decrease of blood volume was much less in the remaining 9 patients, who were normovolaemic or still hypervolaemic after dialsis: $5.81 \pm 5.1 \%($ p 0.02$)$. The decrease of blood volumes was significantly different $(p<0.05)$ between both groups. Ultrafiltration in both groups was comparable: $1657 \pm 790$ and $1544 \pm 735 \mathrm{ml}$ respectively.

In postdialysis underhydrated patients stroke volume decreased from $100.3 \pm 17.5$ to $91.8 \pm 19.6 \mathrm{ml}(\mathrm{p}<0.01)$. HR increased from $68.4 \pm 11.4$ to $82.6 \pm 12.7 \mathrm{~b} / \mathrm{min}(\mathrm{p}<0.001)$ and MAP decreased from $105.5 \pm 14.2$ to $91.3 \pm 11.8 \mathrm{mmHg}(p<0.001)$, while in the remaining 9 patients stroke volume as well as $\mathrm{HR}$ and MAP did not alter $(87.6 \pm 35.5$ to $87.5 \pm 37.4 \mathrm{ml}$, ns; $70.1 \pm 7.2$ to $78.5 \pm 9.9 \mathrm{~b} / \mathrm{min}, \mathrm{ns} ; 97.4 \pm 10.3$ to $87.1 \pm 12.6 \mathrm{mmHg}$, ns; respectively).

\section{Discussion}

In the abscence of an intact renal function the clinician has to guide volume changes. One of his most important tasks is prevention of overhydration as well as underhydration. We have shown in chronic haemodialysis patients, that echography of VCI is of potential value for estimation of dry weight. VCI indices correlated significantly with invasive measured MRAP.

Our results, showing that VCI indices can be used as parameters for both high and low filling pressures, are a confirmation and extension of data of others [4, 6]. Nakao et al reported, however, a correlation between MRAP and VCD and CI which was less good [11]. They measured VCD directly after the QRS complex instead of just before $A$ wave contribution.

Furthermore, they did not measure CI at deep inspiration. In our study respiratory decrease of VCD was evaluated during deep inspiration and 
not during quat respiration in order to get a wider scale of collapse indices and as consequence a better discrimination.

The relation between VCD and MRAP is rather curvilinear than linear, as indicated by our statistical analysis. We do not have enough data points to plot a curve. Dummy regression analysis revealed a curve, that was much alike the curve as was published by Moreno et al [5]. At low MRAP's there was a Iinear relation with the VCD, but above $5 \mathrm{mmHg}$ the distensibility of the vein is decreasing, resulting in a less increase of the VCD at higher MRAP's.

According to our results hypervolaemia (MRAP $28 \mathrm{mmHg}$ ) was defined as a CI of less than $40 \%$ and/or a VCD of above $18 \mathrm{~mm}$. Hypovolaemia (MRAP 43 mmHg) was defined as a VCD of less than $13 \mathrm{~mm}$ and/or a CI of more than 75\%. $89 \%$ of the patients with low VCD had a CI of more than $75 \%$ indicating low filling pressures.

In patients of group II, in which dry weight was determined on clinical grounds, only 6 out of 22 patients had a correct dry weight according to VCI indices, indicating a large discrepancy between dry weights determined by these two methods.

Proof for reliability of the definition of hypowolaemia by VCI indices comes from other results in group II. In patients, who were underhydrated according to VCI indices, stroke volume, MAP and plasma volume decreased significantly after dialysis, while a significant increase of HR was observed. These haemodynamic changes indicate that these patients were indeed underhydrated. No such changes were observed in patients who after dialysis were normovolaemic and/or hypervolaemic according to VCI indices.

The reliability of the $C I$ as a parameter for overhydration was supported by the results of Moreno. He found that a CI of less than 40 : was associated with an MRAP $>7 \mathrm{mmHg}$ (specificity $90 \%$, sensitivity 91\%). In a normal population only 4 out of 65 patients had a CI of less than $40 \div$ 눙.

Concerning the VCD as a parameter of overhydration: in almost all our dialysis patients a VCD $>1 B \mathrm{~mm}$ was associated with a high MRAP $(28$ mmitg). In the study of Moreno a population of 65 patients was described with a known MRAP. From his data we could calculate the specificity and sensitivity of a VCD $\geq 18 \mathrm{~mm}$ as a parameter for overhydration (MRAP $\geq 7$ $\mathrm{mmHg}$ ): 83 웋 and $88 \%$ respectively. However, in healthy controls there 
was a wide variation of the VCD: $18.2 \pm 4.6 \mathrm{~mm}$ [5]. This discrepancy could be explained by the fact that the VCD probably will depend on habitus of the patients as well. Mintz et al suggested to correct VCD per square meter body surface area, and by doing so he found less variation in healthy controls [12]. Haemodialysis patients are often catabolic and have a relatively low lean body mass [13]. So in these patients expression of $\mathrm{VCD} / \mathrm{m}^{2}$ could be of importance.

Studying the relationship between blood volume and $V C D$, more support was delivered for the reliability of VCD as an index of body fluid status. Before dialysis no correlation existed between VCD and blood volume, while after dialysis a significant correlation was found. These observations seem to be contradictory but can be explained as follows. When a dialysis patient becomes hypervolaemic, vCD will increase until VCD has reached his maximal anatomical width. A further increase of volume will result in a small increase of diameter only and a steep increase of pressure [5]. Furthermore, blood will be stored in physiological pooling places, such as venous plexus of liver, intestine and skin [14]. In a situation in which VCD has not reached its maximal anatomical width, as in most patients after dialysis, a significant correlation will exist between VCD and blood volume. However, in a situation where $V C D$ has reached its maximal anatomical width, as in most patients before dialysis, no such correlation can be found. Patients with a high VCD have great variations of high blood volumes, as is seen in our patients before dialysis. During removal of fluid excess in hypervolaemic patients the reverse process will take place. Initially blood volume will decrease slightly because of rapid fluid mobilisation from extravascular compartments. Subsequently vCD will remain almost unaltered until normovolaemia has been reached. In patients, who are hypovolaemic, this fluid mobilisation will occur less rapidly resulting in a decrease of blood volume and subsequently in a decrease of VCD. As is clear from our results, a significant correlation was found between relative changes in VCD and relative changes in blood volume.

In conclusion: A significant correlation was found between VCD, its CI during deep inspiration, and MRAF. Therefore VCD and/or CI can be used as a parameter for both high and low filling pressures. In almost all 
patients a high VCD was associated with large blood rolumes, while in lower blood volume ranges there was a significant correlation of VCD and bllood volume. This is indicating that VCD is pressure and volume related, which is a confirmation of the in vitro data of Moreno et al. In chronic dialysis patients, after excluding patients with severe valwular and pulmonary disease, a VCD of more than 18 mm was associated with overhydration as well as a CI of less than $40 \%$. A WCD of less than $13 \mathrm{~mm}$ was an indication of underhydration, which was often accompanied with a CI of more than $75 \%$. 


\section{References}

1. Henderson LW. Symptomatic hypotension during haemodialysis. Kidney Int 17: S71-S76 (1980).

2. Janssen JHA, Van Engelshoven JA, Cheriex EC, Leunissen KML. Chest $x-r a y$ in patients on chronic haemodialysis: has it any value? Radiologica c/o Sociedade Portuguesa de Radiologia e Medicina Nuclear (in press).

3. Kinet JP, Soyeur D, Balland $\mathbf{N}_{*}$ Saint-Rémy $M$, Collignon, $\mathrm{P}$, Godon JP. Haemodynamic study of hypotension during haemodialysis. Kidney Int 21: $868-876(1982)$ :

4. Natori H, Tamaki S, Kira S. Ultrasonographic evaluation of ventilatory effect on inferior vena caval configuration. Am Rev Resp Dis $421-427$ (1979).

5. Moreno AH, Katz AI, Gold LD, Reddy RV, Tech M. Mechanics of distension of dog veins and other very thin-walled tubular structures. Circ Res XXVII 1069-1080 (1970).

6. Moreno FLL, Hagan AD, Holmen JR, Pryor TA, Strickland RD, Castle $\mathrm{CH}$. Evaluation of size and dynamics of the inferior vena cava as an index of right-sided cardiac function. Am J Cardiol 53: 579-585 $(1984)$.

7. Sahn DJ, De Maria A, Kisslo J, Weyman A. Recommendations regarding guantitations in $M$-mode echocardiographic measurements. Circulation 58: $1072-1083(1978)$.

8. Popp RL, Filly K, Brown OR, Harrison DC. Effect of transducer placement on echocardiographic measurement of left ventricular dimensions. Am J Cardiol 35: 537-540 (1975).

9. Keyes J, Carey J, Mosses D, Beierwaltes $W$. Manual of nuclear medicine procedures (2nd Edition CRS Press Cleveland 95-98, 1973).

10. Tararin RC, Melsher HJ, Dustan HP, Frolick ED. Plasma volume changes with upright tilt: studies in hypertension and in syncope. J Appl Physiol 28: 121-126 (1970).

11. Nakao S, Come PC, Mckay RG, Ransil BJ. Effects of positional changes on inferior vena cava size and dynamics and correlations with right sided cardiac pressure. Am J Cardiol 59: 125-1132 (1987). 
12. Mintz GS, Kotler MN, Parry WR, Iskandrian AS, Kane SA. Real-time inferior vena caval ultrasonography: normal and abnormal findings and tis use in assessing right-heart function. Circulation 64: $1018-1025(1981)$.

13. Heidland $A$, Schaefer RM, Heidbreder $E$, HörI WH. Catabolic factors in renal failure: therapeutic approaches. Nephrol Dial Transpl 3: $8-16(1988)$.

14. Guyton AC. Textbook of Medical Physiology (7th Edition, W.B. Saunders Co, Philadelphia/London/Toronto, 1986». 
CHAPTER III

PLASMa ALPHA-hUMAN ATRIAL NATRIURETIC PEPTTDE AND DRY WEIGHT IN CHRONIC HAEMODIALYSIS

K.M.L. Leunissen, P.P.C.A. Menheere, E.C. Cheriex, B.w. van den Berg, T.C. Noordzij, J.P. van Hooff

Department of Internal Medicine, Clinical Chemistry and Cardiology University Hospital Maastricht, The Netherlands 
The relationship between vena cava inferior diameter (VCD), collaps index (CI) determined by echography and alpha-human atrial natriuretic peptide (alpha-h-ANP) levels were studied in 19 chronic haemodialysis patients. A significant correlation was found between VCD and alpha-h-ANP levels before dialysis $(r=0.78 ;$ pro.0001). No such correlation was found between CI, left atrial diameter and left. ventricular end diastolic diameter, and alpha-h-ANP levels. In 9 patients, who were hypervolaemic before dialysis (group I) according to vena cava indices, alpha-h-ANP levels were significantly higher than in 10 norno- or hypovolaemic patients (group II) according to the vena cava indices: $392.8 \pm 134.1$ respectively $168.0 \pm 62.5 \mathrm{pg} / \mathrm{ml}$. Notwithstanding ultrafiltration of the same amount of fluid in both groups alpha-h-ANp decreased significantly in group $I$ only, whereas in group II the decrease was not significant: $392.8 \pm 134.1$ to $185.2 \pm 81.7$ $(\mathrm{p} \times 0.001) ; 168.0 \pm 62.5$ to $130.0 \pm 59$ respectively. After achieving normovolaemia alpha-h-ANP levels in patients with a mitral valve insufficiency grade I were doubled compared to normovolaemic patients without mitral valve insufficiency. In the latter group alpha-h-ANP levels were approximately doubled compared to healthy controls. The highly significant correlation between VCD before dialysis and changes in alpha-h-ANP during dialysis with fluid removal underlines the value of vena cava diameter in estimating dry weight.

\section{Introduction}

An increased level of plasma alpha-human-atrial natriuretic peptide (alpha-h-ANP) has been reported in dialysis patients [1-2]. During ultrafiltration and haemodialysis with fluid removal serum alpha-h-ANP decreased significantly. This decrease of alpha-h-ANP levels correlated significantly with both loss of body weight and plasma volume [3]. During haemodialysis without ultrafiltration alpha-h-ANP is not dilysed in significant amounts [3-4]. The decrease of alpha-h-ANP during dialysis is therefore due to a diminished production in the atria as a consequence of fluid removal [4].

After fluid removal, however, alpha-h-ANP levels remained elevated above normal range, despite the fact that most patients achieved their 
dry weight [1-3]. Furthermore alpha-h-ANP did not decrease in all patients and a considerable variability in plasma levels after dialysis was noticed [4].

One might explain these findings by assuming an incorrectly estimated dry weight. This assumption can be supported by the well known fact, that it is difficult to estimate dry weight correctly without using invasive monitoring techniques. We therefore developed a simple, abjective and reliable method of estimation [5]. We have shown that echographic measurement of vena cava inferior diameter and collaps index correlates significantly with mean right atrial pressure (MRAP) and blood volume changes [5]. MRAP and blood volume are related to plasma alpha-h-ANP levels as well. [6-10]. If echography of vena cava inferior is indeed a good marker of fluid status, there has to be a significant correlation with alpha-h-ANP levels. The demonstration of such a correlation was the purpose of the present study.

\section{Patients and methods}

Nineteen chronic haemodialysis patients have been studied (age $48.8 \pm 22.7$ years, time on dialysis $3.72 \pm 3.1$ years). Al1 vaso-active medication was stopped 16 hours before the investigations were performed. All haemodialyses were performed with bicarbonate dialysate

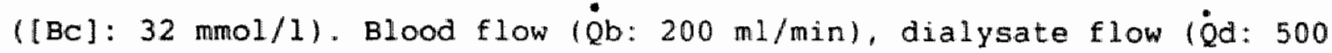
$\mathrm{ml} / \mathrm{min}$ ), artificial kidney (Gambro 120M) and delivery system (Gambro AK10) were the same in all patients. They were dialysed to their dry weight as estimated on basis of clinical parameters and chest $x$-ray parameters. Before and after dialysis echography of the inferior vena cava was performed [5, 11]. The inferior vena cava diameter (VCD) was measured just below the diaphragm in the hepatic segment, the patient lying flat in supine position during 10 minutes. simultaneously electrocardiographic monitoring was done. The diameters were measured before P-wave on ECG to avoid interference with $A$-wave and $W$-waves and were corrected for body surface area. The diameter was measured during expiration and maximal inspiration. Collaps index (CI) was defined as llmaximal diameter on expiration - minimal diameter on deep inspiration) / maximal diameter on expiration] x 100. Left atrial (LA) diameter and left ventricular end diastolic diameter (LVEDD) were measured by M-mode echocardiography. 
Stroke volume was determined by continuous wave Doppler, measuring the systolic integral of the velocity (M/S) over the aortic valve from the apical window and the M-mode systolic aortic cusps separation [12]. The intra- and interobserver variability was $9 \%$ and $11 \%$ respectively. Echography was performed by one of the investigators, who was not informed about fluid status and clinical dry weight. The clinician, who was in charge of haemodialysis, was not informed about the echographic findings .

Blood pressure and heart rate were recorded automatically by an oscillometric recording system (Dynamap, applied medical research, Tampa, Florida, USA).

With the purpose to study during dialysis with fluid removal haemodynamic changes in relation to fluid status prior to dialysis, patients were divided in two groups according to vCI indices before dialysis.

Group I: hypervolaemic patients (VCD $211.5 \mathrm{~mm} / \mathrm{m}^{2}$ and/or CI $40 \%$ ). Group II: normovolaemic $8.0<V C D<11.5 \mathrm{~mm} / \mathrm{m}^{2}, 40<C I \times 758$ ) or hypovolaemic (VCD $\leq 8 \mathrm{~mm} / \mathrm{m}^{2}$ and/or $\left.\mathrm{CI}, 75 \%\right)$. These criteria were obtained by dividing the criteria in the first chapter by 1.6 , the mean surface area of our dialysis population.

Before, halfway and at the end of dialysis plasma alpha-h-ANP was measured with a commercial available assay (INCSTAR BV, Amsterdam). The EDTA plasma (stored at $-20^{\circ} \mathrm{C}$ in the presence of aprotenin, Trasylol, Bayer) was extracted on sep pak $\mathrm{C}-18$ cartridges. The eluate was analysed in a RIA method using a sheep antibody against alpha-h-ANP. The separation step was performed with a horse-anti-sheep precipitating reagent. The first antibody was $100 \%$ cross reactive to human alpha-h-ANP $(1-28), 109$ to ANP $(5-28)$ and 127 to ANP $(7-28)$. Other fragments did not cross react $\llbracket 13-14 \rrbracket$.

The sensitivity of the assay was $1.1 \mathrm{ng} / \mathrm{l}$; the intra assay coefficient of variation was below 48 in the range of $10-100 \mathrm{ng} / \mathrm{l}$ and below 12 in the range of $100-200 \mathrm{ng} / 1$. The Interassay coefficient was less than $10 \%$.

Correlation coefficients were determined by the Pearson Rank test $(\mathrm{p}<0.05$ was regarded statistically significant). Statistical analysis was performed using multiregression analysis. A p-value of less than 
0.001 was regarded statistically significant. The data pre- and postdialysis were analysed with the paired t-test. A p-value of less than 0.025 was regarded statistically significantly different.

\section{Results}

Before dialysis VCD and alpha-h-ANP correlated significantly $(r=0.78$; p(0.0001) (figure 1), whereas $C I$ and alpha-h-ANP did not $(r=-0.3476)$.

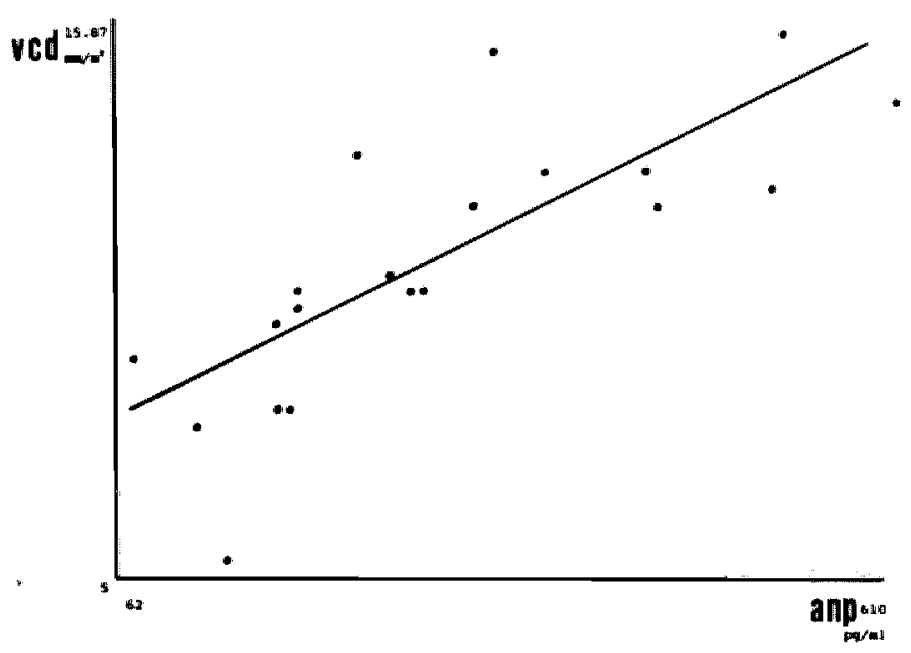

\section{Fiqure 1:}

Scatterplot showing the relation between the vena cava diameter and the alpha-h-ANP level before dialysis.

In multiple regression analysis with alpha-h-ANp as dependent variable and VCD, CI, left atrial diameter and left ventricular end diastolic diameter as predictor variables, only VCD had a significant effect with a multiple $r$ of 0.78 (p<0.0001). No relation was found between the ather variables and alpha-h-ANP levels before dialysis. Taking the changes in alpha-h-AMP levels during dialysis as dependent variable, VCD before dialysis, CI before dialysis, LAD before dialysis and ultrafiltration volume as predictive variables, multiple regression analysis revealed a highly significant correlation between alpha-h-ANP and VCD, $r=-0.72(p<0.001)$ (figure 2 ).

According to vena cava indices before dialysis patients were divided into 2 groups. Group I: 9 patients who were hypervolaemic. Group II: patients who were either normovolaemic $(n=8)$ or hypovolaemic $(n=2)$. 


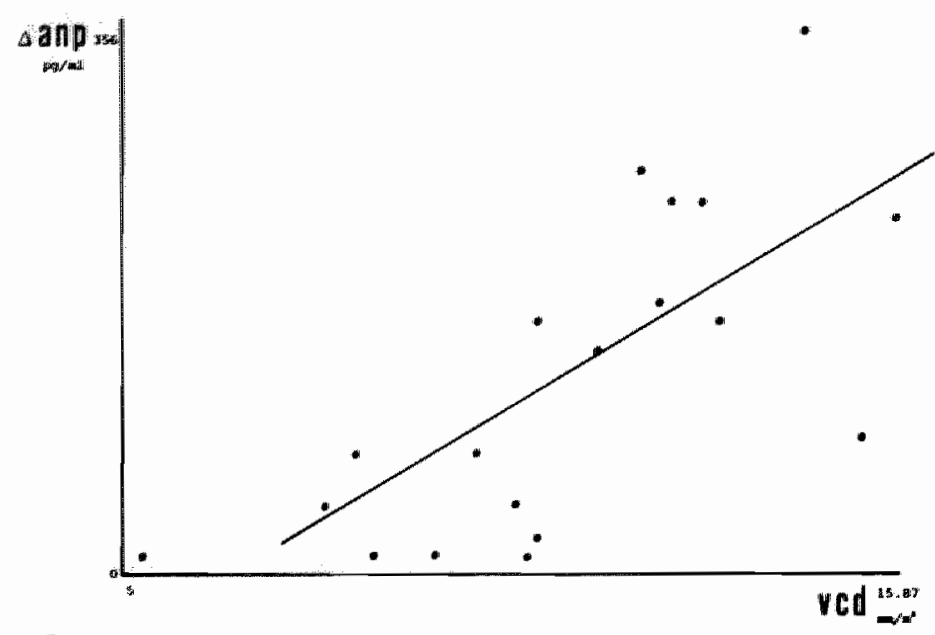

iqure 2:

scatterplot showing the relation between the vena cava diameter (YCD) before dialysis and the change in alpha-ANp level during dialysis with fluid removal.

patients normovolaemic and 1 patient hypovolaemic. In group II 8 patients were hypovolaemic and 2 normovolaemic. Ultrafiltration volume did not differ significantly between both groups.

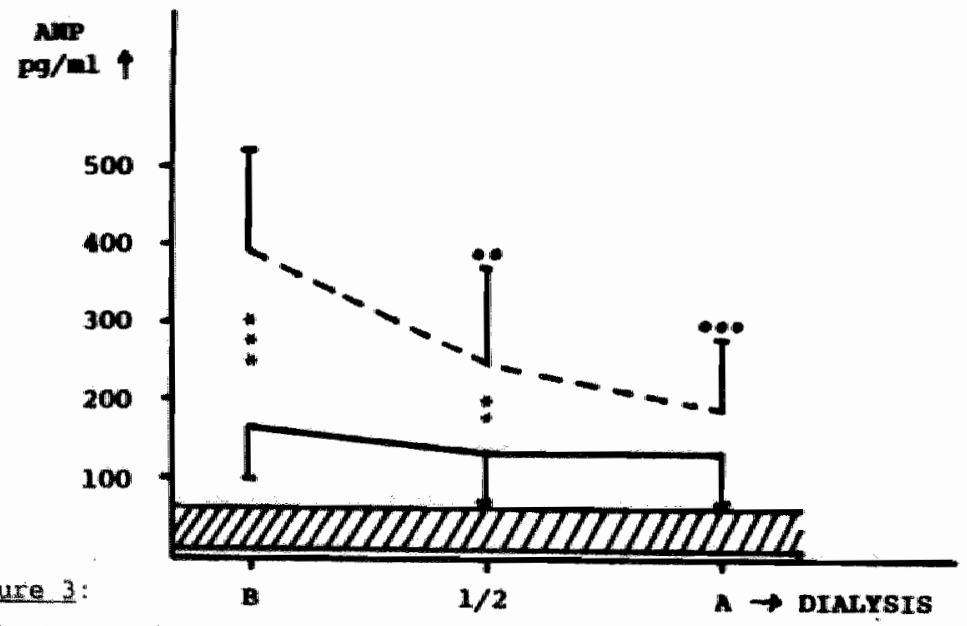

Alpha-h-ANp levels during dialysis with an equal amount of fluid removal in 9 patients, who were hypervolaemic according to vCI indices (dotted line) and in 8 normovolaemic and 2 hypovolaemic patients according to ver indices (solid linel.

The hatched bar represents the alpha-ANp range in healthy volunteers.

- represents a significant difference between the alpha-ANP levels at $\frac{1}{2}$ and after dialysis compared to the value before dialysis ("p p.0.01;

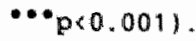

* represents a significant difference between both groups (**p<0.01; $* * * \mathrm{p} \times 0.001)$. 
Table I:

Changes pre- and postdialysis in 9 hypervolaemic patients according to VCI indices (group I) and in 8 normovolaemic and 2 hypovolaemic patients according to VCI indices (group II).

$$
\begin{array}{cc}
\text { group I } & \text { group II } \\
(n=9) & (n=10) \\
45.1 \pm 20.4 & 53.5 \pm 21.6
\end{array}
$$

Mean age (years) $45.1 \pm 20.4$

\begin{tabular}{lrrrrr}
\multicolumn{1}{c}{ before } & \multicolumn{1}{l}{ after } & \multicolumn{1}{l}{ before } & after \\
\hline VCD & $13.5 \pm 1.4 * \star$ & $11.0 \pm 1.7$ & $9.1 \pm 1.8 * \star *$ & $7.3 \pm 2.0$ \\
CI & $54.0 \pm 16.9 *$ & $71.6 \pm 19.3$ & $67.3 \pm 16.5 * * 77.2 \pm 11.0$ \\
LAD & $49.1 \pm$ & $6.8 *$ & $46.7 \pm 6.4$ & $43.4 \pm 5.9 * * 40.7 \pm 5.7$ \\
LVEDD & $49.8 \pm$ & 4.5 & $48.3 \pm 5.1$ & $47.9 \pm 4.2$ & $46.1 \pm 5.4$ \\
SV & $101.2 \pm 29.7$ & $97.2 \pm 26.8$ & $102.2 \pm 27.3 * * 90.5 \pm 32.0$ \\
MAP & $103.2 \pm 10.3 * * 93.0 \pm 10.3$ & $97.5 \pm 16.9 * * 80.3 \pm 13.7$ \\
HR & $77.0 \pm 15.3$ & $78.5 \pm 12.8$ & $84.9 \pm 20.5 *$ & $92.9 \pm 21.9$ \\
UFV & & & $2161 \pm 1040$ & & $1882 \pm 729$ \\
Alpha-h-ANP & $392.8 \pm 134.1 * * * 185.2 \pm 81.7$ & $168.0 \pm 62.5$ & $130.0 \pm 59$ \\
\hline
\end{tabular}

${ }^{*} \mathrm{p}<0.025 ; * \star \mathrm{p}<0.01 ; * * \star \mathrm{p}<0.001$

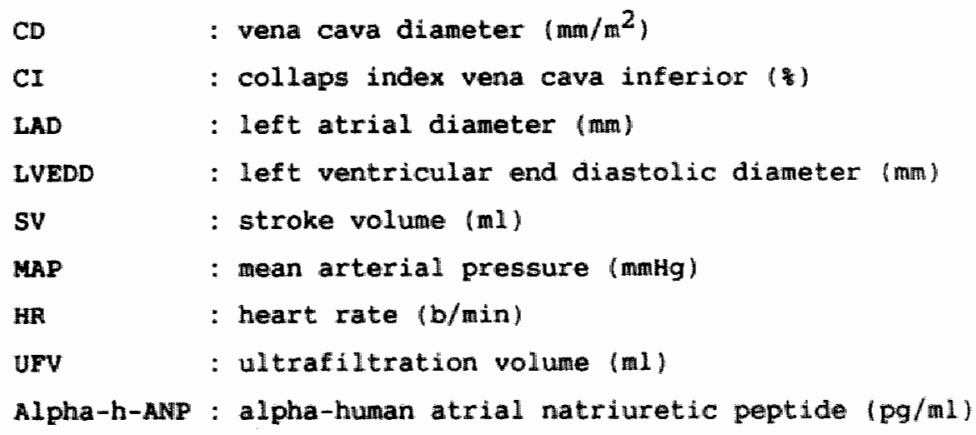

After dialysis VCD, CI, LAD and MAP changed significantly in group $I$, while $H R$ remained unaltered (table I).

In group II LAD, SV and MAP decreased significantly, while HR increased significantly (table I).

Before dialysis alpha-h-ANP of group $I$ was significantly higher compared to group II $(392.8 \pm 134.1$ and $168.0 \pm 62.5$ respectively). Although at the end of dialysis alpha-h-ANP in group I was somewhat higher as compared to group II, this difference was not significant (figure 3). 
3 Patients in group $I$ and 2 patients in group II had a MI grade I (MI) without signs of pulmonary hypertension. After achieving normovolaemia in these patients, alpha-h-ANP levels were $250.0 \pm 60.5$ and $200 \pm 68$ in group I and II respectively. After dialysis nomovolaemic/hypovolaemic patients without mitral valve insufficiency had the same alpha-h-ANP in group I $(n=4)$ and group II $(n=8), 107.8 \pm 29.0$ and $112.5 \pm 41.4 \mathrm{pg} / \mathrm{mI}$.

\section{Discussion}

It has been shown that alpha-h-ANP release is related to volume expansion and probably to MRAP as well, both leading to an increased wall stress of the right atrium $[6,9,15]$.

From our previous study it was concluded, that VCD as well as CI have a significant correlation with MRAP. Only after dialysis vCD correlated significantly with total blood volume, while before dialysis a high vCD was associated with variable high blood volumes (chapter I). In the present study we have shown that before dialysis a highly significant correlation exists between alpha-h-ANP and VCD. No correlation could be demonstrated between alpha-h-ANP levels and $C I$, left atrial or left ventricular end diastolic diameters.

From the above mentioned the assumption can be made that during volume expansion release of alpha-h-ANP mainly takes place in the right atrium. Our findings seem to be at variance with findings of Haas et al [15]. They not only found a significant correlation between alpha-h-ANP and MRAP and right atrial diameter, but also with left atrial diameters [15].

studying our patients with MI grade I without pulmonary hypertension separately, it turned out that after achieving dry weight, alpha-h-ANP levels were almost doubled compared to patients without MI.

From our data and data of Haas et al the conclusion might be drawn that in fluid overloaded haemodialysis patients without valvular heart disease alpha-h-ANP is mainly produced in the right atrium, stimulated by volume expansion. However, in patients with $M I$ resulting in altered left atrial haemodynamics, substantial extra alpha-h-ANP release will occur possibly from the left atrium.

Alpha-h-ANp was significantly higher in hypervolaemic patients according to vena cava indices compared to normovolaemic and 
hypovolaemic patients. After dialysis with fluid removal, alpha-h-ANP decreased only in hypervolaemic patients, who after dialysis were normovolaemic or hypovolaemic. Patients who after dialysis still were fluid overloaded kept elevated alpha-h-ANP levels as well.

During dialysis with fluid removal in patients who before dialysis were either normo- or hypovolaemic, alpha-h-ANP did not decrease, notwithstanding the fact that the same amount of fluid was removed as in hypervolaemic patients. Underhydration in the former group was confirmed by the occurrence after dialysis of an increase of HR and decrease of stroke volume and MAP. These findings suggest that vCI indices might indeed be good markers for body fluid status.

After dialysis alpha-h-ANP levels in normo- and hypovolaemic patients were doubled compared to values of healthy controls $(8-69 \mathrm{pg} / \mathrm{ml})$.

ather factors than volume expansion must contribute to this increased alpha-h-ANP. This increase is probably due to an impaired metabolic and excretory clearance in patients with renal failure [3].

In conclusion, in haemodialysis patients basal values of alpha-h-ANP are doubled compared to normal controls. These levels of alpha-h-ANP signify either normovolaemia or hypovolaemia. The presence of higher levels of alpha-h-ANP in the abscence of MI are an indication of fluid overload. However, in the presence of MI no predictive value for body fluid status can be ascribed to a raised alpha-h-ANF. The absence or presence of a decrease of alpha-h-ANP during dialysis with fluid removal rather than an absolute value is giving an indicaton for body fluid status. The highly significant correlation between vCD before dialysis and changes of alpha-h-ANP during dialysis underlines the value of determination of VCD for estimation of dry weight in chronic haemodialysis patients. 


\section{peferences}

1. Wilkins MR, Wood JA, Adu D, Lote CJ, Kendall MJ, Michael J. Change in plasma immunoreactive atrial natriuretic peptide during sequential ultrafiltration and haemodialysis. Clin science 71 : $157-160(1986)$.

2. Rascher $W$, Tulassay $T$, Lang RE. Atrial natriuretic peptide in plasma of volume overloaded children with chronic renal failure. Lancet i1: 303-305 (1985).

3. Cannella G, Rodella A, Brunori G, Gaggiotti M, Sandrini M, Maiorca $R$. plasma concentrations of atrial natriuretic peptide in relation to body fluid status in chronic uraemia. Nephrol Dial Transpl 2: $158-160(1987)$.

4. Kojima S, Inone I, Hirata $Y$, Kimura G, Saito F, Kawano, Y, Satani $M$, Ito $K$, Omae $T$. Plasma concentrations of immunoreactive atrial matriuretic polypeptide in patients on haemodialysis. Nephron 46 : $45-48(1987)$.

5. Leunissen KML, Cheriex EC, Janssen JHA, Mooy JMV, Van Hooff JP. The inferior vena cava diameter and collapsibility index and the optimal dry weight in chronic haemodialysis patients. Nephrol Dial Transp1 2: $438(1987)$.

6. Sato F, Kanoi $K$, Wakiya $Y$. Relationship between atrial natriuretic peptide levels and atrial pressure in man. $J$ Clin Endocrinal Metabol 63: 823-827 (1986).

7. Richards AM, Nicholls MG, Ikram $\mathbb{H}$, Webster MWI, Yandle, TG, Espiner EA. Renal haemodynamic and hormonal effects of human alpha atrial natriuretic peptide in healthy volunteers. Lancet ii: $545-548(1985)$.

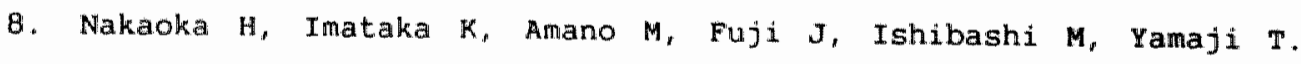
plasma levels of atrial natriuretic factor in patients with congestive heart failure. N Engl J Med 313: 892-893 (1985).

9. Lang RE, Tholken $H$, Gamten $D$, Luft FC, Ruskoako $H$, Unger $T$. Atrial natriuretic factor - a circulating hormone stimulated by volume loading. Nature (London) 314: 254-266 (1985).

10. Tikkanen I, Fyhrquist F, Metsarinne K, Leidenius R. Plasma atrial natriuretic peptide in cardiac disease and during infusion in healthy volunteers. Lancet i: 66-69 (1985). 
11. Moreno FLL, Hagan AD, Holmen JR, Pryor TA, Strickland RD, Castle CH. Evaluation of size and dynamics of the inferior vena cava as an index of right-sided cardiac function. Am J Cardiol 53: 579-585 $(1984)$.

12. Bouchard A, Blumlein S, Schiller NB, Schlitt S, Byrd BF III, Ports $\mathrm{T}$, Chatterjee $\mathrm{K}$. Measurement of left ventricular stroke volume using continuous wave Doppler echocardiography of the ascending aorta and M-mode echocardiography of the aortic valve. I An Coll Cardiol 9: $75-83(1987)$.

13. Kangawa $K$, Matsuo $H$. Purification and complete acid sequence of alpha human atrial natriuretic peptide. Biochem Biophys Research Commun 118: 131-139 (1984).

14. Rosmalen FMA, Tan AITL, Tan HS, Benraad THJ. A sensitive radio-immuno assay of atrial natriuretic peptide in human plasma, using a tracer prepared with an immobilized glyco-uril agent. Clin Chim Acta $165: 331-340$ (1987).

15. Haas $M$, Fischer TA, Dietz $R$. Is atrial distension the physiological stimulus for release of atrial natriuretic peptide? Lancet ii: 1269-1270 (1987).

16. Hasegawa $K$, Matsushita $Y$, Inone $T$. Plasma levels of atrial natriuretic peptide in patients with chronic renal failure. J Clin Endocrinol Metab 63: 819-822 (1986). 
THE INFLUENCE OF FLUID REMOVAL DURING HAEMODTALYSIS ON MACRO- AND SKIN MICROCIRCULATION

K.M.L. Leunissen, B.W. van den Berg, E.C. Cheriex, D.W. Slaaf, R.S. Reneman, J.P. van Hooff

Department of Internal Medicine, Cardiology, Biophysics and Physiology University Hospital Mastricht, The Netherlands 


\section{Abstract}

Changes of macro- and microcirculation during haemodialysis and fluid removal are probably dependent on ultimate fluid status and on the efficacy of various regulation mechanisms, especially the catecholamines. This was studied in 20 chronic dialysis patients. Pre- and postdidysis stroke volume, mean arterial pressure, heart rate and systemic vascular resistance were measured. Furthermore, microcirculation was studied by Laser doppler flow and by intravital microscopy of finger nailfold, measuring red blood cell velocity and capillary density. pre- and postdialysis noradrenaline and adrenaline were measured. Mine patients proved to be hypvolaemic after dialysis (group I) and 11 patients proved to be normovolaemic or less hypervolaemic (group II) according to vena cava inferior parameters. There was a significant decrease of mean arterial pressure and stroke volume in group I, and an increase of heart rate, whereas in group II there was only a decrease of mean arterial pressure. Systemic vascular resistance did not change in both groups. Moradrenaline decreased, although not significantly in both groups, whereas in group $I$ adrenaline increased significantly. There was a significant decrease of skin perfusion in group $I$, whereas in group II there was a significant increase. Capillary density increased significantly in group II after reaching normovolaemia.

Underhydration was leading to microcirculatory changes on basis of a decrease of stroke volume and an increase of adrenaline, while ultrafiltration leading to a normal fluid status induces microcirculatory changes, which are related to arterial and venous pressure changes and their effect on the myogenic response as a local autoregulatory effect.

\section{Introduction}

Haemodialysis is often complicated by symptomatic hypotension. Factors such as ultrafiltration rate, cardiovascular state, sodium concentration and buffer substrate of the dialysate are involved in the occurrence of hypotension under these circumstances [1-4]. Conflicting results have been reported with respect to the macrocirculatory changes during haemodialysis and fluid removal. A poorly corrected estimate of 
fluid status might explain some of these contradictory results. However, accurate assessment of fluid status on clinical parameters was difficult to achieve. Recently, echography of the inferior vena cava has been shown to provide reliable information about fluid status of chronic dialysis patients $[5$, chapter I].

So far the effects of dialysis and fluid removal on the microcirculation have not been studied in detail. Under these circumstances, changes in the macrocirculation and microcirculation are dependent on the efficacy of various regulating mechanisms. The release and pharmacological effects of catecholamines are of importance in regulating cardiac performace and peripheral resistance during haemodialysis. However, conflicting results have been reported in regard to catecholamine profiles during dialysis and their pharmacological effects $[6-10]$.

The aim of the present study was to investigate during haemodialysis the effects of changes of extracellular fluid volume (ECV) on the macro- and microcirculation and the role of catecholamines as a regulating mechanism in relation to the fluid status after dialysis.

\section{patients and methods}

Twenty chronic dialysis patients were included in the study. Mean age was $48.8 \pm 22.7$ years and time on dialysis $3.72 \pm 3.1$ years. All wasoactive medication was stopped 16 hours before the investigations were done. All treatments were performed with bicarbonate dialysis ([BC]: 32 mmol/1) and a calcium concentration of $1.75 \mathrm{mmol} / 1$, resulting in a slow linear correction of acidosis and a significant increase of serum Ionized calciurn $[11]$. Blood flow $(\dot{Q} b=200 \mathrm{ml} / \mathrm{min})$, dialysate flow (Q்d: $500 \mathrm{ml} / \mathrm{min}$ ), artificial kidney (Gambro 120M) and delivery system (Gambro AK10) were the same in all patients. They were dialysed to their clinical dry weight in 3 hours, as estimated by one independent investigator on basis of clinical parameters. Just before and immediately after dialysis echography of the inferior vena cava was performed by another investigator, who was not informed about the clinical parameters [5]. The inferior vena cava diameter was measured in the anterior-posterior direction just below the diaphragm in the 
hepatic segment. The collapsibility index (CI) was defined as: [maximal diameter on expiration - minimal diameter on deep inspiration / maximal diameter on expiration] x 100 [5].

Ascending aortic blood flow velocity was measured with a continuous wave doppler system [12] and the diameter of the aorta was determined by means of bidimensional echocardiography. From these variables cardiac output (CO) was calculated. Stroke volume was assessed from co and heart rate values. Before and during dialysis each 15 minutes blood pressure and heart rate were recorded automatically with an oscillometric recording system (Dynamap, Applied Medical Research, Tampa, Florida, USA).

Systemic vascular resistance (SVR) was calculated according to the formula (CVP = central venous pressure):

SVR $=80 \times$ (MAP - CVP) dyne $\mathrm{sec} \cdot \mathrm{cm}^{-5}$

$\mathrm{CO}$

The microcirculatory studies, blood pressure measurements and laboratory investigations were done by a third investigator, who was not aware of the results obtained by echography. The microcirculation was studied by means of a Laser Doppler device (Perimed KB), measuring an integral of cutaneous blood $f l u x$ in microvessels and shunts in the skin $[13-14]$. Measurements were continuously performed at the finger nailfold. With this method arbitrary perfusion units are measured, so relative changes rather than absolute values are calculated.

Furthermore, capillary red blood cell velocity, capillary density and diameter of the arteriolar and venular limb of capillary loops were measured before and after dialysis with use of intravital microscopy [15-17]. The measurements were performed at a fixed region of the finger nailfold. A philips LOH 0402 camera was used with a $2 / 3$ inch ultricon register tube. Images were registered on a videotape (Sony Superbetamax SL-HF 950). The used monitor was a Sony PVM-122CE. In al1 experiments microscopy was performed with a Ploenopak (1x) illuminator in combination with a POL-cube. Light was provided by a mercury vapor lamp (100w: Calflex heat reflection filter; DC-power supply) 5\% and 30* grey filters were used in the experiments. The objetives used were a Leitz $P L-F l u o b a r ~(10 x)$ with a numerical aperture of 0.30 and a Leitz PL-APO $4 \mathrm{x}$ with a numerical aperture of 0.14 . The interpixel distance was at $10 x$ magnification $1.25 \mu \mathrm{m}$, and at $4 \mathrm{x}$ magnification $3.125 \mu \mathrm{m}$. The effective width of a videascreen for measuring capillary density was at $4 x$ magnification $1800 \mu \mathrm{m}$. 
Capillary red blood cell velocity was measured with the flying spot method in the arterial limb of the capillary loop at a 10 times magnification [18]. In this technique spots moving over the videoscreen are synchronized with the moving pattern of red blood cells and gaps inbetween. The density of the capillary loops in the nallfold was determined in the distal row along the edge of the nailfold with an objective $4 x$. The number of the capillary loops per videoscreen (effective width $1800 \mu \mathrm{m}$ ) was assessed (19). The diameters of the arterial and venular limbs were measured using the objective $10 x$. Because capillary walls could not be delineated, the diameters given refer to the dimensions of the red blood cell columns. All measurements were performed at a constant room temperature of about $22^{\circ} \mathrm{C}$. Laser Doppler flux was registered continuousiy. Fifteen minutes after starting dialysis, halfway dialysis and at the end of dialysis blood samples were taken for determination of moradrenaline ([NA]) and adrenaline ([A]) (HPLC method: interassay variance $(8 \%$ ) and ionized plasma calcium ([Ca $\left.{ }^{2+}\right]$ ) (Fresenius ionometer).

According to the findings at echography of the inferior vena cava after dialysis, patients were divided into two groups, group I being the hypovolaemic and group II being the normovolaemic or still hypervolaemic patients [5].

statistical analysis was performed with use of a paired student t-test. A p-value of less than 0.05 was regarded as statistically significant. correlation coefficients were determined by the Pearson's test (statistically significance at p 0.05 ).

\section{Results}

According to the findings at echography of inferior vena cava 9 patients were found to be hypovolaemic after dialysis (group I) (table 1). In this group prior to dialysis 1 patient was hypervolaemic, 6 patients were normovolaemic and 2 patients hypovolaemic. In group II 8 patients were normovolaemic and 3 patients hypervolaemic after dialysis. In this group prior to dialysis 2 patients were in a normovolaemic range and 9 patients were hypervolaemic. Ultrafiltration volume (UFV) was comparable in both groups. In group I stroke volume (Sv), mean arterial pressure (MAP) and inferior vena cava diameter 
(VCD) decreased significantly, while heart rate (HR) and collaps index (CI) of the VCI increased significantly (table 1). However, systemic vascular resistance (SVR) did not change. Only two of the hypovolaemic patients after dialysis had a symptomatic hypotension requiring the infusion of $0,9 \% \mathrm{NaCl}$. In group II VCD decreased significantly, while MAP and SV did not change significantly. HR and SVR did not change and there was a significant increase in CI (table 1). After excluding the 3 still hypervolaemic patients after dialysis in group II, MAP decreased significantly from $103.7 \pm 14.7$ to $87.7 \pm 3.5 \mathrm{mmHg}(\mathrm{p}<0.01)$.

Table 1:

Macrocirculatory parameters before and after dialysis in hypovalaemic patients after dialysis and in normo- or less hypervolaemic patients after dialysis. Means $\pm S D$ are indicated.

Hypovolaemic

Group I $(n=9)$

\begin{tabular}{|c|c|c|c|c|c|c|}
\hline & Before & & After & Before & & After \\
\hline SV & $93.0 \pm 21.0$ & $\star * *$ & $81.5 \pm 24.4$ & $105.4 \pm 31.3$ & $\mathrm{~ns}$ & $100.5 \pm 29.8$ \\
\hline MAP & $96.8 \pm 15.0$ & $\star \star$ & $79.8 \pm 14.6$ & $103.6 \pm 12.3$ & ns & $94.9 \pm 13.5$ \\
\hline HR & $86.4 \pm 18.1$ & $\star *$ & $98.0 \pm 19.2$ & $75.4 \pm 15.8$ & ns & $75.1 \pm 12.7$ \\
\hline SWR & $1115 \pm 383$ & ns & $1106 \pm 361$ & $1230 \pm 476$ & ns & $1257 \pm 519$ \\
\hline VCD & $9.1 \pm 2.3$ & $\star \star \star$ & $6.2 \pm 1.1$ & $12.7 \pm 1.4$ & $\star \star *$ & $11.3 \pm 1.7$ \\
\hline $\mathrm{CI}$ & $68.6 \pm 15.2$ & $\star \star$ & $85.8 \pm 5.9$ & $51.8 \pm 16.9$ & * & $67.6 \pm 17.0$ \\
\hline UFV & & & $1922 \pm 788$ & & & $2179 \pm 997$ \\
\hline
\end{tabular}

$* p<0.05 ; * * p<0.01 ; * * * p<0.001$

SV : stroke volume (mi)

MAP: mean arterial pressure $\{(n m H g)$

HR : heart rate (beats/min)

SVR: systemic wascular resistance (dyne. $\sec . \mathrm{cm}^{-5}$ )

VCD: vena cava dismeter $\left(\mathrm{mm} / \mathrm{m}^{2}\right)$

CI : collaps index vena cava inferior $(\$)$

UFV: ultrafiltration volume (mi)

Microcirculatory data are presented in table 2. In group I there was a significant decrease in Laser Doppler flux (LD) and capillary red blood cell velocity (RBCV). The diameter of the venular 1 imb of the capillary loop (CVD) decreased significantly, while there was no change in the 
diameter of the arteriolar limb of the capillary loop (CAD) and capillary density. In group II, however, LD flux and RBCV increased significantly as well as CD (table 2), whereas CVD and CAD decreased significantly in this group.

\section{Table 2:}

Microcirculatory parameters before and after dialysis in hypovolaemic patients after dialysis and in normo- or less hypervolaemic patients after dialysis. Means $\pm S D$ are indicated.

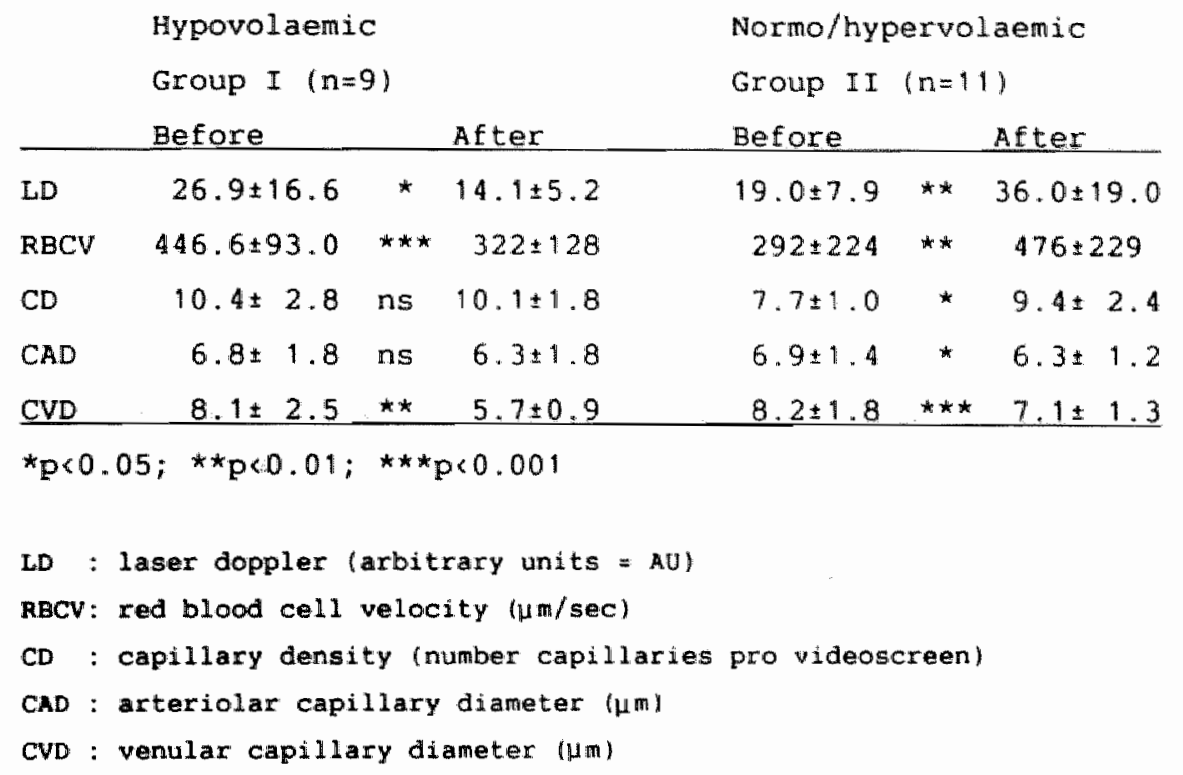

In hypervolaemic patients before dialysis, who were normovolaemic after dialysis, LD flux registration showed a specific pattern (figure la). There was an increase in LD flux during dialysis. The opposite pattern was seen in normovolaemic patients, who were dehydrated after dialysis (figure $1 \mathrm{~b}$ ). In these patients LD flux decreased. In the hypovolaemic patients, who were further dehydrated, the flux as assessed by LD barely changed throughout dialysis (figure $1 \mathrm{c}$ ). The changes in LD flux preceded the changes in MAP.

In group I serum noradrenaline (NA) level significantly decreased during the first half of dialysis and remained constant thereafter (figure 2). In group I serum adrenaline (A) levels did not change during the first half of dialysis, but significantly increased during the second part (figure 2). In group II A-levels decreased slightly in 

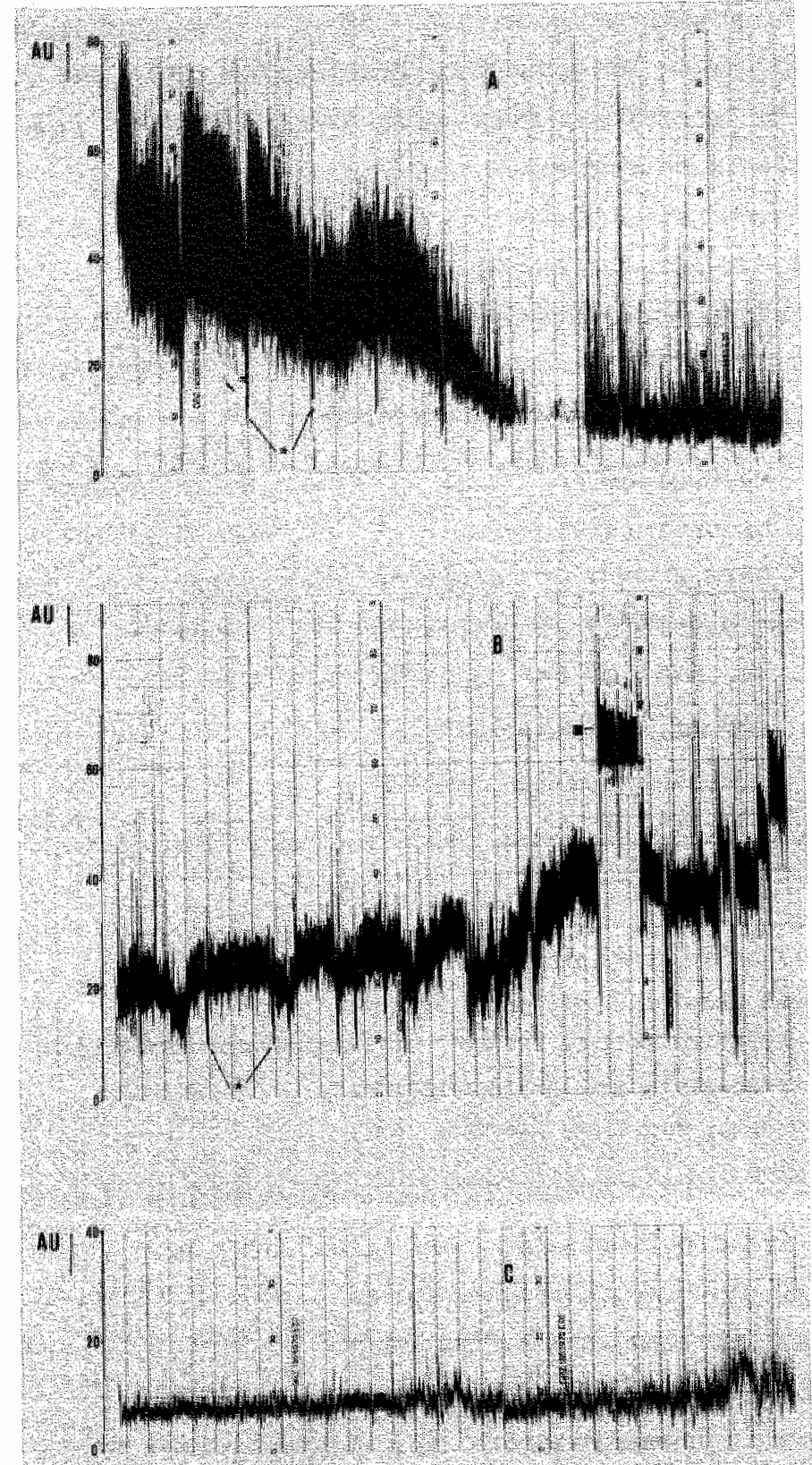

\section{Eicure 1:}

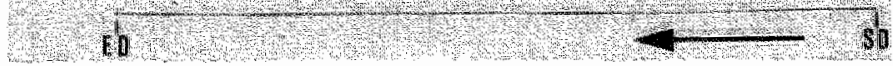

Laser doppler registration from a patient:

(a) hypervolaemic before dialysis and normovolaemic after dialysis

(b) normovolaemic before dialysis and hypovolaemic after dialysis

(c) hypovolaemic before dialysis and more hypovolaemic after dialysis.

SD: start of dialysis $E D=$ end of dialysis

$A U=$ arbitrary perfusion units

= artefact

* = blood pressure measurement 

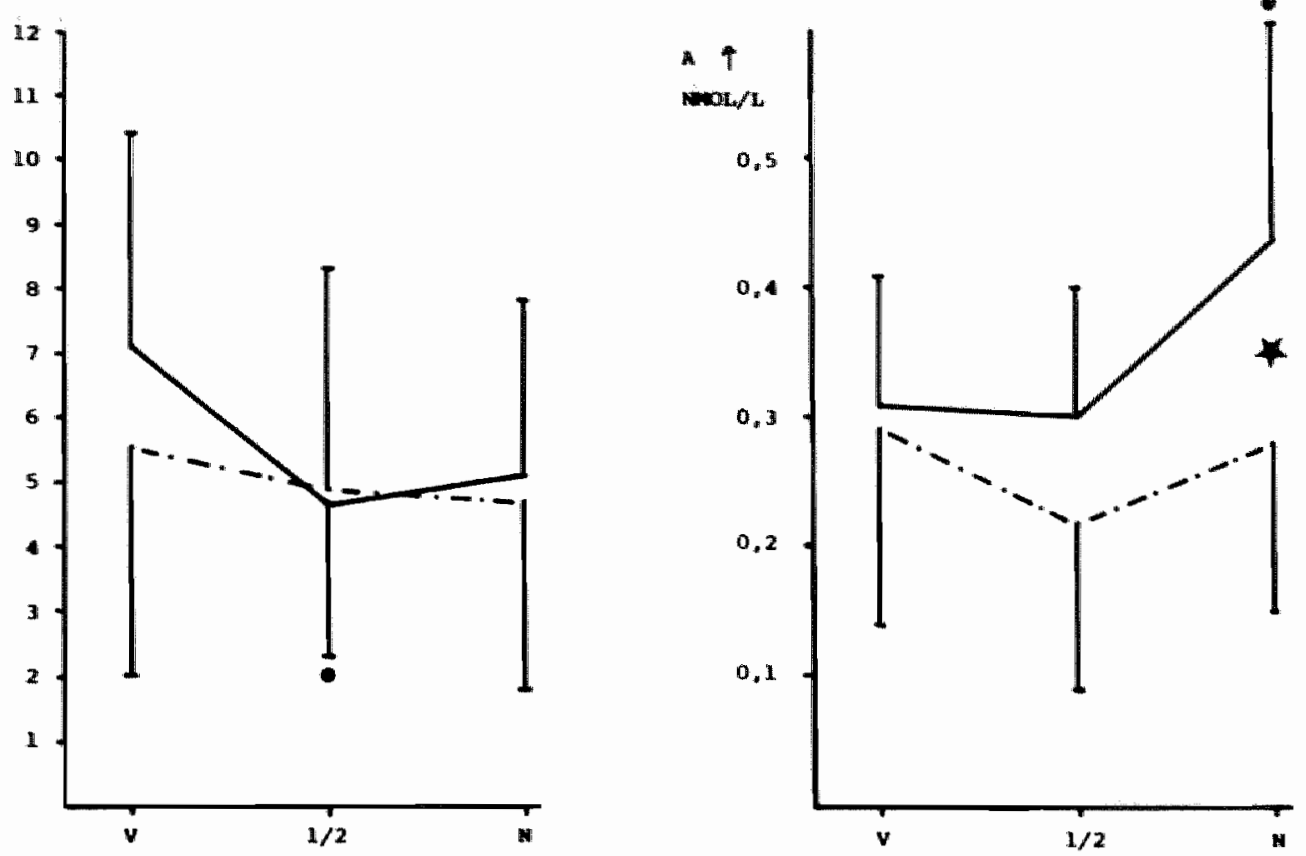

\section{Fiqure 2:}

Noradrenaline (NA) and adrenaline profiles during dialysis in patients hypovolaemic before and normovolaemic after dialysis (dotted lines) and in patients normovolaemic/hypovolaemic before and hypovolaemic after dialysis (solid lines).

$X$-axis: $V=$ before dialysis; $1 / 2$ a half dialysis; $N=$ after dialysis

- Significant difference between levels during dialysis and the level at the start of dialysis of both groups $(" p<0.051$.

* Significant difference between the levels of both groups at the different times during dialysis (*pe0.0.25).

the first half of dialysis, but after dialysis they were similar to levels before dialysis. After dialysis A-levels of group I and II were significantly different (figure 2 ). In group II of one patient a tube was broken, so results are obtained from 10 patients.

Ionized calcium increased significantly in both groups from $1.10 \pm 0.09$ to $1.23 \pm 0.10$ and from $1.10 \pm 0.11$ to $1.22 \pm 0.08$ mol/1, respectively (p<0.01 and $p<0.001$, respectively).

When pooling the data of group I and II a significant correlation between VCD and changes of $L D$ and RBCV was found $(r=0.61, p \times 0.01$ and $r=0.66$, $p(0.005$, respectively) (figure 3). No correlation was found between $C I$ and changes of LD $f l u x$ and RBCV. Changes of LD $f I u x$ and RBCV correlated significantly $(r=0.71 ; p<0.001)$. Furthermore, there was a 
significant correlation between the percentual decrease of VCD and the decrease of CVD $(r=0.71 ; p<0.001)$.
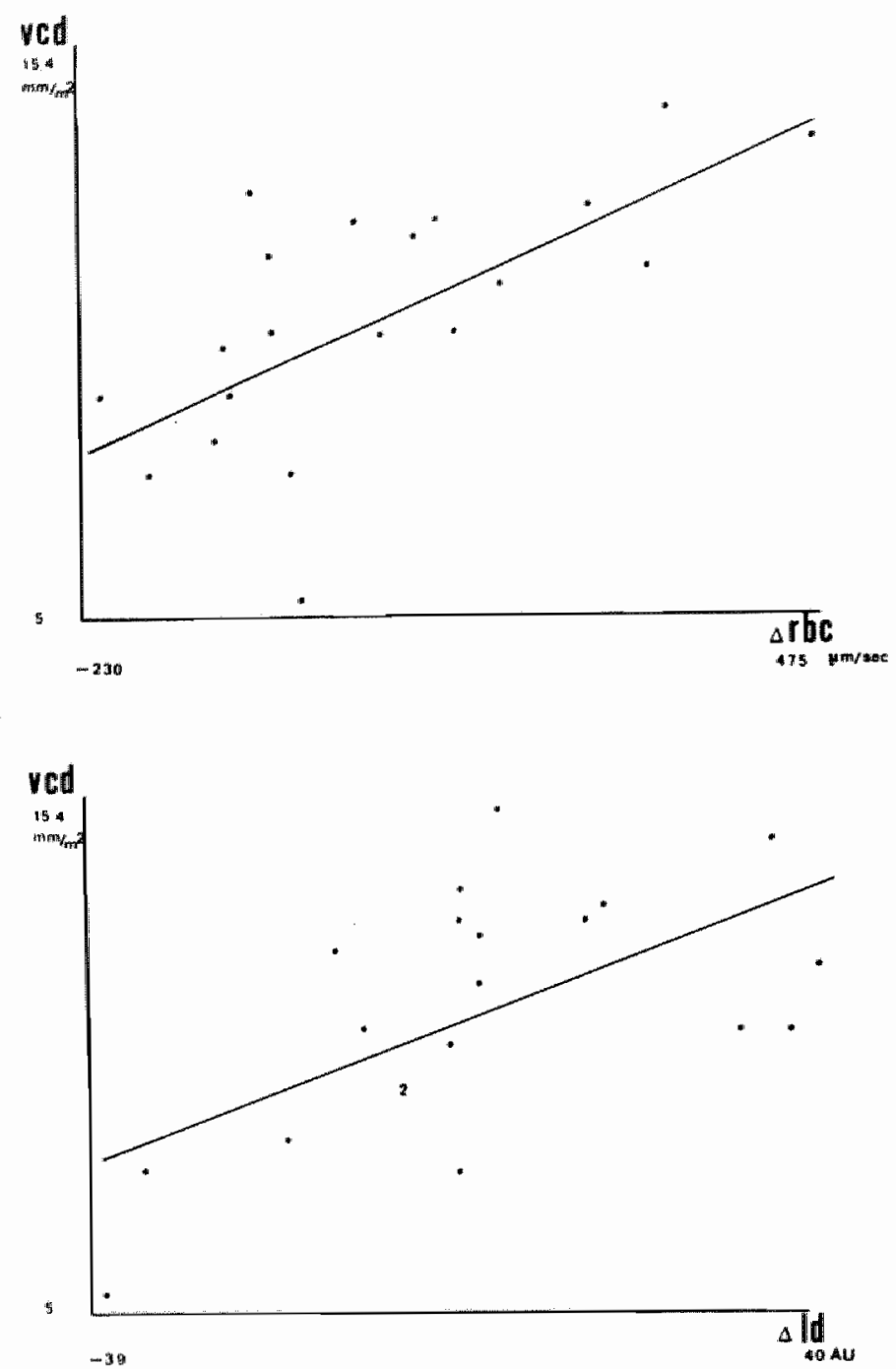

\section{Fiqure 3:}

Scatterplot of the relation between VCD (vend cava inferior diameter) before dialysis and the changes in red blood cell velocity (ARBCV) (upperpart), and the changes in Laser Doppler (DLD) (lower part) as a consequence of dialysis and fluid removal.

\section{Discussion}

When studying haemodynamic changes during dialysis with fluid removal, ultimate fluid status after dialysis was found to be of crucial importance. Notwithstanding the same ultrafiltration volume, major 
changes in macrocirculation were observed only in patients, who were hypovolaemic after dialysis. In these patients stroke volume and mean arterial pressure decreased significantly and heart rate increased significantly, while in postdialysis normo- and hypervolaemic patients no major haemodynamic changes were observed, except for a decrease in mean arterial pressure in those patients, who were normovolaemic after dialysis. This can be attributed to the decrease of extracellular volume and consequently of plasma volume.

However, we have shown that, depending on the ultimate fluid status after dialysis, a decrease of extracellular volume by ultrafiltration will lead to different changes in plasma volume [5]. The refilling rate of plasma volume is related to the degree of hydration of the tissues [20]. One way to explain this is by assuming that total tissue compliance varies with tissue hydration [21-24]. Tissue compliance is high in hypervolaemia, resulting in a high plasma refilling rate [20]. Tissue compliance is low near normovolaemia and in hypovolaemia and fluid removal will cause a fall in tissue pressure, which opposes transport into the vascular compartment $[20]$, resulting in a low plasma refilling rate.

In the hypovolaemic group, mean arterial pressure decreased significantly due to a decrease of stroke volume. However, contrary to the expectation, no secondary increase of systemic vascular resistance was observed [25-27]. This might partially be due to the decrease of noradrenaline levels. During dialysis noradrenaline decreased in the hypovolaemic patients after dialysis, whereas an increase was expected due to hypovolaemia [25]. This decrease is related to the considerable clearance of catecholamines during dialysis [28]. The fact that there was an increase in serum adrenaline levels in the hypovolaemic patients after dialysis indicates that there was a large release of adrenaline, most probably from the adrenals. Catecholamine released from the adrenals, is predominantly adrenaline [29]. Noradrenaline induces an increase in systemic vascular resistance [29], whereas adrenaline induces an increase in heart rate without an important effect on systemic vascular resistance [29]. The fact that despite decreasing noradrenaline levels systemic vascular resistance did not decrease in the hypovolaemic patients after dialysis, can likely be explained by the significant increase of ionized calcium and the correction of the acidosis by bicarbonate dialysis. Both factors amplify the pharmacological effect of catecholamines $[30-31]$. 
These findings indicate that macrocirculatory changes, as induced by dialysis due to fluid removal are partly related to the ultimate fluid status after dialysis.

Microcirculatory changes during dialysis were dependent on the ultimate fluid status after dialysis as well. In hypovolaemic patients after dialysis Laser Doppler flux and capillary red blood cell velocity decreased significantly during dialysis, indicating a decrease in skin perfusion. In the initially hypervolaemic patients Laser Doppler flux and red blood cell velocity increased significantly during dialysis, indicating that in this situation skin perfusion is increased. In hypovolaemic patients after dialysis the decrease of skin perfusion is probably caused by the decrease of stroke volume, because there was no change in capillary density in these patients. Furthermore the increase of adrenaline will contribute to a decrease of skin perfusion, because this catecholamine preferentially inhibits cutaneous blood flow [32]. The decrease in central venous pressure could partially explain the reduction of venular capillary diameters. This idea is suported by the finding that the relative decrease in inferior vena cava diameter correlated significantly with the decrease in venular capillary diameter. However, experimental studies, using a pressure box to change venous pressures, revealed that relatively high pressure changes are needed to induce small variations in the diameter of venous capillaries [33-35]. The 30\% decrease of venular capillary diameter in the hypovolaemic patients after dialysis can not readily be explained by the concomitant decrease in venous pressure. The hypovolaemic state could account for this discrepancy and, furthermore, it should be stressed that the above mentioned studies were performed with acute pressure changes of maximal 5 minutes.

The increase of skin perfusion in the initially hypervolaemic patients can not be explained by macrocirculatory changes. Stroke volume, mean arterial pressure and systemic vascular resistance did not change, neither did adrenaline levels. In these patients prior to dialysis red blood cell velocity, laser doppler flux and capillary density were low. This could be explained by the high mean arterial pressure and venous pressures, both inducing a myogenic response, leading to arteriolar vasoconstriction $[36]$. 
An increase of extracellular fluid volume induces a decrease of capillary density [37]. A decrease of capillary density was observed without changes in cardiac output and blood pressure in healthy volunteers after a short term increase in sodium intake (37). After dialysis and ultrafiltration in the initially hypervolaemic patients there was a decrease of mean arterial pressure and venous pressure, resulting in an increase of red blood cell velocity, capillary density and Laser Doppler flux.

These results indicate that underhydration leads to microcirculatory changes merely due to changes in cardiac performance and increased adrenaline production. Ultrafiltration, leading to normalisation of extra cellular fluid volume, induces microcirculatory changes, which are merely related to arterial and venous pressure changes and subsequently local autoregulatory effects [36]. 
1. Bergström $J_{,}$Asaba $H$, Furst P, Oules R. Dialysis, ultrafiltration and blood pressure. Proc Eur Dial Transpl Assoc 13: 293 (1976).

2. Ruder $M A$, Alpert $M A$, Van stone $J$, et al. Comparative effects of acetate and bicarbonate haemodialysis on left ventricular function. Kidney int $27: 768-733$ (1985).

3. Baldamus $C_{\text {, Ernst }}$, Frei $U$, Koch KM. Sympathetic and hemodynamic response to volume removal during different forms of renal replacement therapy. Nephron 31: 324-331 (1982).

4. Aizawa $Y$, Ohimori $T$, Imai K, Nara $Y$, Matsuoka M, Hirasawa $Y$. Depressant action of acetate upon the human cardiovascular system. Clin Nephrol 8: 447-480 (1977).

5. Leunissen KML, Cheriex EC, Janssen JHA, Mooy JMV, Van Hooff JP. Echography of vena cava inferior is a simple and reliable tool for estimation of "dry weight" in haemodialysis patients. Blood Purif 5: 293-294(1987).

6. Rouby $J$, Rottembourg $J$, Durande JP, Basset $J-Y$, Degoulet P, Glaser $P$, Legrain $M$. Hemodynamic changes induced by regular haemodialysis and sequential ultrafiltration haemodialysis: a comparative study. Kidney Int 17: 801-810 (1980).

7. Textor SC, Haralambos G, Tifft CP, Bernard DB, Idelson B, Brunner HR. Norepinephrine and renin activity in chronic renal failure (evidence for interacting roles in haemodialysis hypertension). Hypertension 3: 294-299 (1981).

8. Lilley JJ, Golden J, Stome RA. Adrenergic regulations of blood pressure in chronic renal failure. J Clin Invest 57: 1190-1200, $(1976)$.

9. Campese VM, Romoff MS, Levitan D, Lane K, Massry SG. Mechanisms of autonomic nerwous system dysfunction in uraemia. Kidney Int 20: $246-253(1981)$.

10. Henrich WL, Katz FH, Molinof PB, Schrier RW. Competitive effects of hypokalaemia and volume depletion on plasma renin activity, aldosterone and catecholamine concentrations in haemodialysis patients. Kidney int 12: 279-284 (1977).

11. Leunissen KML, Van den Berg BW, Van Hooff JP. Ionized calcium plays a pivotal role in controlling blood pressure during haemodialysis. Blood Purif (in press). 
12. Vandenbogaerde JF, Vanholder RC, Everaert JA, vogelaers DF, Colardijn FA, Ringoir SM, Clement DL. Cardiac output changes during haenodialysis with ultrafiltration. Clin Nephrol 29: 8892 (1988).

13. Kristensen JK, Engelhardt M, Nielsen T. Laser doppler measurement of digital blood flow regulation in normals and in patients with Raynauds phenomenon. Acta Dermatovener 63: 43-47 (1983).

14. Nilsson GE, Tenland T, öberg PA. A new instrument for continuous measurement of tissue blood flow by light beating spectroscopy. IEEE Trans Biomed Engl 27: 12-19 (1980).

15. Bollinger A, Butti PO, Barras JP, Trachsler $H$, Siegenthaler $W$. Red blood cell velocity in nailfold capillaries of men measured by a television microscope technique. Microvasc Res 7: $61-72$ (1974).

16. Slaaf DW, Jongsma FBM, Tangelder GJ, Reneman RS. Characteristics of optical systems for intravital microscopy. Microcirc Technol 211-228 (1986).

17. Bollinger A, Mahler F, Anliker M. Velocity of red blood cells in human nailfold capillaries. Acta Chir Scand 465(suppl): 7-9 (1976).

18. Tyml $K$, Ellis $C G$. Evaluation of the flying spot technique as a television method for measuring red cell velocity in microvessels. Int J Microcirc Clin Exp 1: 145-155 (1982).

19. Jacobs MJHM, Breslau PJ, Slaaf DW, Reneman RS, Lemmens JAJ. Nomenclature of Raymond's phenomenon: a capillary microscopic and haemorheologic study. Surgery 101: 136-145 (1987).

20. Koomans HA, Geers AB, Dorhout Mees EJ. Plasma volume recovery after ultrafiltration in patients with chronic renal failure. Kidney Int 26:848-854 (1984).

21. Aukland $K$, Nicolaysen $G$. Interstitial fluid volume: local regulatory mechanisms. Physiol Rev 61: 556-632 (1981).

22. Guyton AC. Interstitial fluid pressure II. pressure volume curves of the interstitial space. Circ Res 16:452-460 (1965).

23. Reed RK, Wiig $H$. Compliance of the interstital space in rats. $I$. Studies on hindlimbs skeletal muscle. Acta Physiol Scand 113: 297305 (1981).

24. Wiig H, Reed RK. Compliance of the interstitial space in rats. II. Studies on the skin. Acta Physiol scand 113: 307-315 (1981). 
25. Lake CA, ziegler MG. Effect of acute volume alterations on notepinephrine and dopamine-8-hydrowylase in normotensive and hypetenswe subjects. Circulation 57: 774-778 1978).

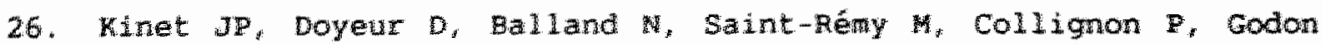
IP. Haemodynamic study of hypotension during haemodialysis. Kidney Int 21: 868-876 (1982).

27. Wies AS, Robertson D, Stone WJ. Haemodialysis hypotension is not the result of uremic peripheral autonomic neuropathy. I Lab cin Med 94: 395-402 1979:.

28. Zucchelli P, Catizone $t$, Degli Esposti E, Ligabue A, Zuccala A. Influence of ultrafitration on plasma renin activity and adrenergic system. Wephron $21: 317-324$ (1978).

29. Guyton AC. Textbook of Medical Physiology. W.B. Saunders Company, Philadelphia/London/Foronto, 7th Edition (1986).

30. Khalil $R_{\text {, Lodge }}$, Saida $K$, Van Breemen $C$. Mechanism of calcium activation in vascular smooth muscle. J yypert 5: S5-s15 (1987).

31. Williamson JR, Safer $B$, Fich $T$, Schaffer 5 , Kobayashi K. Effects of acidosis on mocardial contractility and metabolisms. Acta Med Scand $587: 95-112(1975)$.

32. Goodman LS, Gilman A. The pharmacological basis of therapeutics. MacMillan Company London, th Edition, 1970.

33. Slaaf DW, Reneman RS, wiederhielm $C A$. Pressure regulation in muscle of unanesthetized bats. Microvasc Res 33: 315 (1987).

34. Bouskela E, wiederhielm C. Viscoelastic properties of capillaries. Microvasc Res 17: S1 (1979).

35. Davis MJ. Microvascular control of capillary pressure during increases in local arterial and venous pressure. Am $J$ physiol 254: $4772(1988)$.

36. Johnson PC. The myogenic response. The cardiovascular system. Handbook of physiology. Section 2: volume II: 409-442. Executive Editor: SR Geiger, American Physiological society, Bethesda Maryland (1980).

37. Ghione $S$, Bertuglia S, Colantuoni A, Ebert FG, Fomei E, Rosa C, Mezzasalma L, Gazetti P, Ebert AG, Marabotti C, Meconi P, Palombo C. Haemodynamic and microvascular changes after a short term increase in sodium intake in young normal volunteers. J Hypert 4 : S195i-S197 (1986). 


\section{CHAPTER $v$}

ACETATE VERSUS BICARBONATE HAEMODIALYSIS IN CRITICALLY ILL PATIENTS

K.M.L. Leunissen, S.J. Hoorntje, H.A. Fiers, W.T. Dekkers, A.W. Mulder

Department of Internal Medicine

Catharina Hospital Eindhoven, The Netherlands 


\section{Abstract}

The haemodynamic state, the acid-base balance and the bloodgases were studied in 9 acute renal failure patients during recirculation acetate and bicarbonate dialysis. A significant haemodynamic instability, due to a decreased cardiac performance, was observed during acetate dialysis, whereas during bicarbonate dialysis there was a stable naemodynamic state. During acetate dialysis $\mathrm{PO}_{2}$ dropped significantly, due to a decreasing ventilatory drive as a consequence of the significantly lower $\mathrm{pCO}_{2}$ in acetate dialysis. From these findings we conclude that bicarbonate dialysis should be the first choice in the treatment of acute renal failure patients.

\section{Introduction}

The main problem during haemodialysis of critically ill patients is the occurrence of haemodynamic instability. Its causes are obviously multifactorial and both patients- and procedure-related [3, 14, 37]. As for the latter, the acetate in the dialysate as a possible important factor causing unstable haemodynamics during the haemodialysis procedure has often been studied $[1,6,9,13,25-30,32-34,36,38$, 431. In some studies acetate has been shown to possess vasodilator properties [3, 17, 21] with an increased cardiac output (co) $117,20-$ 21], whereas in other studies it is said to have cardiodepressent properties $[1,19,42]$. A possible decrease of acetate metabolism of patients with multiple organ failure could accentuate these effects either by its direct impacts or indirectly by interference with the acid-base metabolism.

We investigated the effects of acetate versus bicarbonate dialysis. The haenodynamic parameters and the changes of the acid-base metabolism and gasexchange during the two haemodialysis procedures were compared.

\section{patients and methods}

The studies were performed in the Intensive Care Unit. All patients suffering from acute renal failure were eligible, except the ones that needed mechanical or pharmacological support of the circulation. In total a number of 12 paired studies in 9 patients could be obtained 
during this period. The clinical data of the 9 patients are shown in table I. The two dialysis manoeuvres were performed at random for each patient. The patients were dialysed every day during 2 hours. Both dialysates contained the following ions $(\mathrm{mEq} / 1)$ : sodium 138 , potassium 1.0, calcium 3.5, magnesium 1.0. The bicarbonate dialysate contained in addition $(\mathrm{mEg} / 1)$ bicarbonate 35 , chloride 105.5, and acetate 3, whereas the acetate dialysate contained no bicarbonate, chloride 103.5 and acetate $40 \mathrm{mEq} / 1$.

The composition of the dialysates was verified by laboratory analysis in each experiment. The same dialyzer (Tecno $50 \mathrm{c}$, cuprophan) and delivery system (Bellco unimat, functioning according to the recirculation principle) were used in each experiment. The remaining characteristics of the dialysis procedure were kept constant: dialysate flow 500, blood flow $200 \mathrm{ml} / \mathrm{min}$. Vascular access was obtained either by double lumen femoral or subclavian catheters. As for the rate of ultrafiltration, it was determined separately for each patient, since it depended on the clinical state of the patients and the left cardiac filling pressures. The rate was kept constant in each pair of studies. Haemodynamic recordings were obtained before dialysis, each 0.5 hour during dialysis and 1 hour after termination of the dialysis. The pulmonary capillary wedge pressure (PCWP) and central venous pressure (CVP) were measured with a Swan Ganz thermodilution catheter (type: 93A-131-7F, Edwards Lab.). CO was measured by the thermodilution method (comp. 9520, Edwards Lab.). At least three injections were performed for each measurement with the USCI thermodilution injector 372000 . Blood pressure (MAP) was recorded continuously by means of an intraarterial line. The heart rate (HR) was determined from a simultaneous electrocardiographic recording. From this set of parameters we calculated the systemic vascular resistance (SVR):

SVR $=80 \times \llbracket$ MAP-CVP】 dyn. $5 \cdot \mathrm{cm}^{-5}$,

CO

and left ventricular stroke work index (LVSWI)

LVSWI $=C I \times$ MAP $\times 0.0144 \times 1000 \mathrm{~g} \cdot \mathrm{m} \cdot \mathrm{m}^{2}[4]$.

HR

All blood chemistry measurements were performed with a radiometer (ABL 3 IzH Copenhageny. Lactate was measured by an enzymatic method and arterial acetate levels by isothachophoresis [12]. Plasma osmolality was determined by freezing-point depression. Data points were examined 
Table 1:

Clinical data of the studied patients

Patient sex Age Etioliology of renal

Dialysis

Ventilation Failure

sequence

\begin{tabular}{|c|c|c|c|c|c|}
\hline 1 & $q$ & 52 & Glomerulosclerosis & $\mathrm{BiC}-\mathrm{Ac}$ & Spontaneous $1 \mathrm{y}$ \\
\hline 2 & s & 52 & $\begin{array}{l}\text { Acute cardiac fai- } \\
\text { lure }\end{array}$ & $\mathrm{BiC}-\mathrm{AC}$ & Spontaneously \\
\hline 3 & or & 51 & $\begin{array}{l}\text { Desophageal varicous } \\
\text { bleeding } \\
\text { Hypovolaemia }\end{array}$ & $A C-B i c$ & Spontaneously \\
\hline 4 & $a^{*}$ & 51 & $\begin{array}{l}\text { Sepsis multiorgan } \\
\text { failure }\end{array}$ & $A C-B i C$ & Mechanical \\
\hline 5 & 9 & 52 & $\begin{array}{l}\text { Polycystic renal } \\
\text { disease / Sepsis }\end{array}$ & $\mathrm{BiC}-\mathrm{AC}$ & Spontaneously \\
\hline 6 & $\sigma^{*}$ & 68 & $\begin{array}{l}\text { Atherosclerotic re- } \\
\text { nal dysfunction } \\
\text { Mitral valve insuf - } \\
\text { ficiency gr. IV }\end{array}$ & $A C-B i C$ & Spontaneously \\
\hline 7 & $a$ & 68 & Cardiac failure & $A C-B I C$ & Spontaneously \\
\hline 8 & $d$ & 68 & $\begin{array}{l}\text { Hypovolaemia and } \\
\text { sepsis after Bricker } \\
\text { operation }\end{array}$ & $B i C-A C$ & Spontaneously \\
\hline 9 & $\$$ & 60 & $\begin{array}{l}\text { Cervix carcinoma, } \\
\text { postrenal abstruc- } \\
\text { tion / Ascites. } \\
\text { decreased cardiac } \\
\text { performance }\end{array}$ & $A C-B i C$ & Spontaneously \\
\hline 10 & $o$ & 68 & $\begin{array}{l}\text { Reperfusion ischaemic } \\
\text { leg and hypovolaemia }\end{array}$ & $B i C-A C$ & Spontaneously \\
\hline 11 & $\sigma^{*}$ & 73 & $\begin{array}{l}\text { Ruptured aneurysm } \\
\text { aortae / Sepsis }\end{array}$ & $A C-B i C$ & Mechanical \\
\hline 12 & $a^{*}$ & 67 & $\begin{array}{l}\text { M. Kahler, hypercal- } \\
\text { ciaemia / Sepsis }\end{array}$ & $B i C-A C$ & Mechanical \\
\hline
\end{tabular}

Bic: bicarbonate; AC: acetate 
at the same monents as the haemodynamic recordings. The data were analysed with student's paired t-test. A p-value of $<0.05$ was considered to be significant. All results are reported as means \pm SEM.

\section{Results}

A significant fall in MAP and LVSWI was observed during acetate dialysis (figure 1). Moreover, MAP decreased below the level of $60 \mathrm{~mm} g$ during 3 acetate dialyses, whereas the LVSwI decreased below the generally accepted critical level of 40 u during 8 acetate dialyses, indicating a very poor cardiac performance.

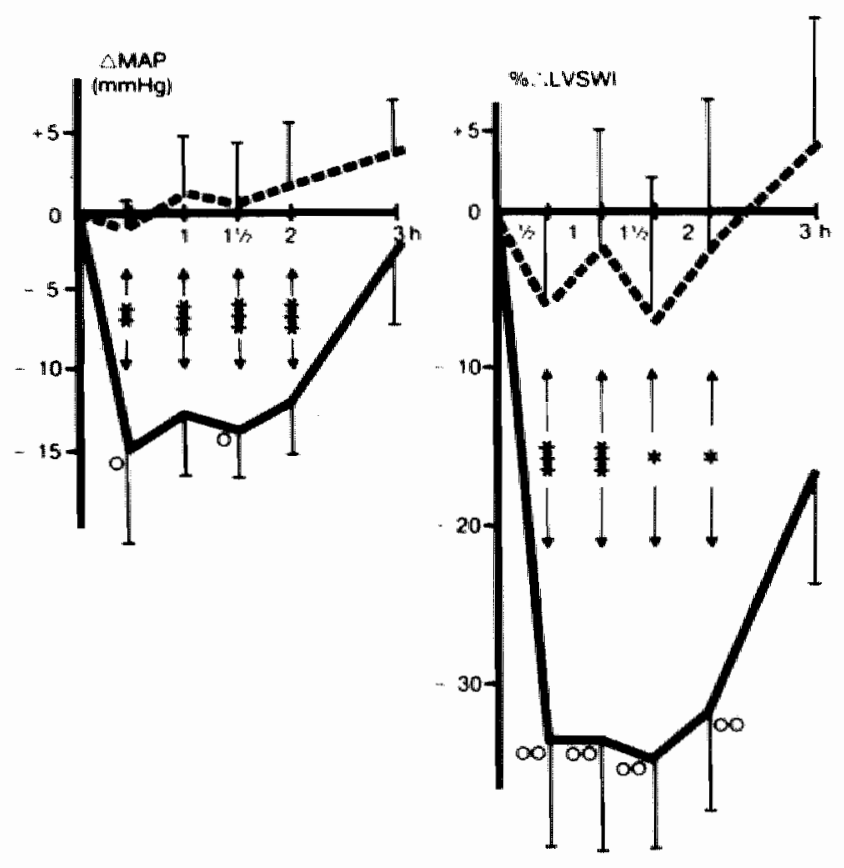

\section{Fiqure 1:}

Haemodynamic effects of recirculation dialysis with bicarbonate (dotted lines) and acetate (solid lines) in 12 paired dialyses. Means \pm SEM are indicated.

Abbreviations:

MAP: mean arterial pressure.

LVSWI: left ventricular stroke work index.

Asteriks (*: $p<0.05 ; * *: p<0.02 ; * *: p<0.011)$ represent significance between groups. Circles $1^{\circ} ; \mathrm{p} \times 0.05 ; 0^{\circ}:$ p 0.01$)$ represent significance between the absolute measurements at time zero and at the different times during dialysis. 
On the other hand, bicarbonate dialysis was well tolerated by all patients. We observed a significant difference in MAP and LVSWI between acetate and bicarbonate dialysis during the whole procedure, whereas co differed significantly only during the first hour (table II). It is noteworthy that a deterioration of the haemodynamic state was still present as long as 1 hour after termination of the acetate dialysis. An equal rise in pulse rate was observed during both procedures (table II) and the SVR also increased again. No difference in rise could be established between the two procedures (table II). Finally, neither PCWP nor the ultrafiltration rate differed significantly. The overall ultrafiltration rate was comparable in both types of dialyses: during acetate dialysis $4.9 \pm 1.2 \mathrm{ml} / \mathrm{min}$ and during bicarbonate dialysis $5.2 \pm 1.5$ $\mathrm{mil} / \mathrm{min}$ (NS).

A gradual increase of $\mathrm{pH}$ was measured during both types of dialyses. However, metabolic acidosis was not corrected during 5 acetate dialyses (pH<7.35). Three of the latter patients were mechanically ventilated. During bicarbonate dialysis none of the patients remained acidotic. A gradual increase of $\mathrm{HCO}_{3}$ and $\mathrm{pH}$ was observed during this procedure.
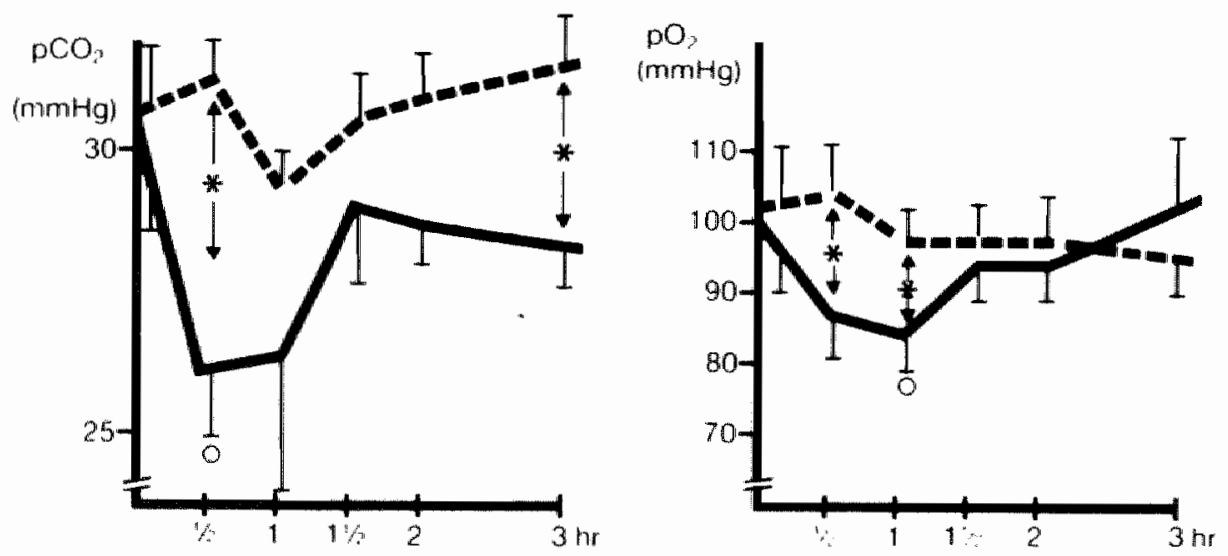

\section{Finuge 2 :}

Bloodgas analysis during bicarbonate (dotted lines) and acetate (solid lines) recirculation dialysis in twelve paired dialyses. Means \pm SEM are indicated.

Asteriks 1*: pro.05; **: pro.02; ***: $p<0.01$ represent significance between groups. Circles $\left({ }^{\circ}: p<0.05 ; 0: p<0.01\right)$ represent significance between the absolute measurements at time zero and at the different times during dialysis. 


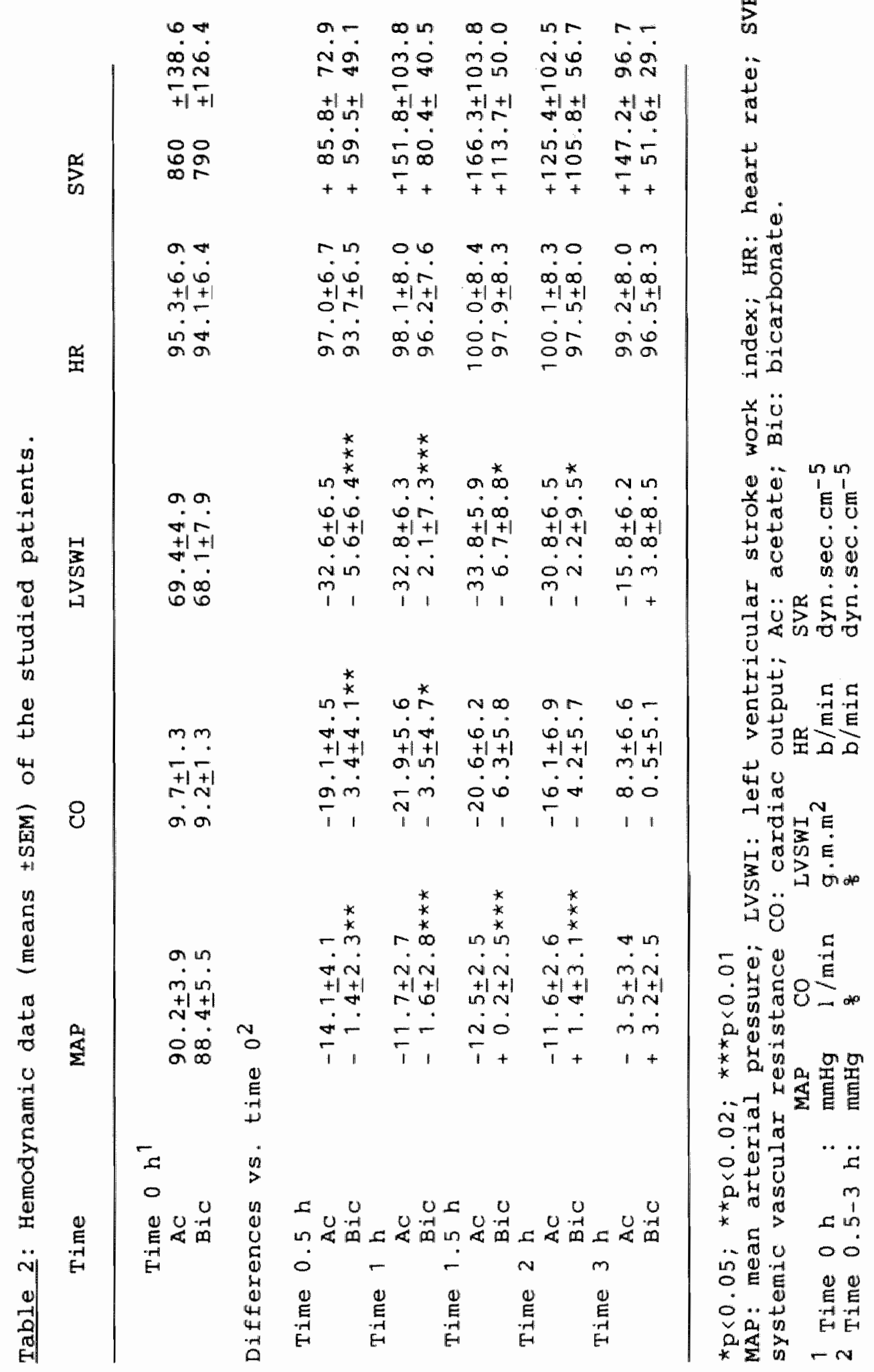


$\mathrm{pCO}_{2}$ dropped during acetate dialysis in the spontaneously breathing patients and we observed a significant difference in $\mathrm{pCO}_{2}$ in comparison with bicarbonate dialysis at 0.5 hour (figure 2). Finally, $\mathrm{pO}_{2}$ dropped significantly during acetate dialysis in the first hour, whereas no major changes were noticed during the other procedure.

The maximum mean arterial acetate level was measured 1 hour after starting dialysis and was 3.7 mmol/1. Only in one patient (No. 6), the acetate level rose to 28.80 .5 hour after starting dialysis: all other patients failed to achieve peak acetate levels of $5.0 \mathrm{mmol} / 1$. One hour after dialysis, the mean acetate 1 evel was less than $0.1 \mathrm{mmol} / 1$.

There was no hyperlactacidaemia during acetate or bicarbonate dialysis. During acetate dialysis, the mean maximal value of lactate was $2.5 \pm 0.6$ and during bicarbonate dialysis $1.7 \pm 0.3 \mathrm{mmol} / 1$ (NS).

The fall in osmolality was comparable in both types of dialyses: acetate dialysis $-14.1 \pm 3.0 \quad \mathrm{H}_{2} \mathrm{O}$, bicarbonate dialysis $-15.5 \pm 2.7 \mathrm{mosm} / \mathrm{kg}$ $\mathrm{H}_{2} \mathrm{O}$ (NS).

Finally, as for the efficacy of the dialysis, we observed a mean decrease (25\%) of BuN after 2 hours of dialysis in both types of dialyses. During acetate dialysis, the serum urea level fall was $11.2 \pm 2.0 \mathrm{mmol} / 1$, during bicarbonate dialysis $12.4 \pm 2.54 \mathrm{mmol} / 1$ (NS).

\section{Discussion}

The aim of this study was to compare acetate with bicarbonate dialysis in critically 111 patients. Sodium acetate instead of bicarbonate is used in practically all of the current dialysate preparations because of precipitations of calcium and magnesium salts. Since delivery systems that utilize bicarbonate are available, one is able to investigate the alleged pivotal role of acetate in the development of haemodynamic instability during haenodialysis in critically ill patients [23].

As demonstrated by our results, no major haemodynamic instability occurred during bicarbonate dialysis. In contrast, acetate dialysis caused considerable circulatory problems in our series. MAP and Co decreased significantly during acetate dialysis in comparison with the bicarbonate procedure. A difference in $H R$ and SVR was observed in neither of the two types of dialysis. Therefore and because of the fact that cardiac filling pressures and ultrafiltration rates were also 
strictly comparable during both procedures, the haemodynamic instability cannot be readily explained by extracardial effects. The observed significantly lower LVSWI thus indicates an impairment of myocardial performance during acetate dialysis, resulting in circulatory problems. our results are in complete agreement with the study of Azaiwa et al. [1] and Ruder et al [32], who demonstrated a significantly better left ventricular performance in patients treated with bicarbonate dialysis. However, these and most other studies comparing acetate and bicarbonate dialysis have been carried out in stable patients on a chronic haemodialysis program. Until now, only two studies have been published that compared both types of dialysis in critically ill patients 15, 42]. Vincent et al [42] observed an important decrease of cardiac performance during his studies in 5 patients during acetate dialysis, whereas the bicarbonate procedure did not cause haemodynamic instability. However, data points were examined only at the beginning and end of dialysis. Moreover, there were no data concerning the acidbase balance and blood-gas analysis during dialysis. Vincent et al. proposed that the acetate would be the cause of the impaired myocardial performance without measuring the acetate blood levels. The observations made in this and our study are challenged by the study of Borges [5], who reported a similar incidence in hypotensive periods in 30 acute renal failure patients, dialysed alternately with acetate and bicarbonate dialysis. Haemodynamic monitoring was not performed invasively, and the frequency of the blood pressure measurements was not mentioned. In dialysing haemodynamic instable patients, a constant ultrafiltration rate is important. The use of a bed weighting scale as in the study of Borges et al. only approximates an exact control of the ultrafiltration rate. The most important difference to our study is the fact that Borges et al. were infusing routinely Mannitol during the first 4 dialyses. As demonstrated by the study of Hsu et al. [15], this could rule out the influence of the difference in plasma refiling during acetate and bicarbonate dialysis. Blood-gas analysis and acidbase balance measurements were only done 2 and hours after starting dialysis.

The cause of haemodynamic instability and deterioration of cardiac performance during acetate dialysis is obscure. Except for one, all patients failed to achieve peak arterial acetate levels of about 5.0 moll1, when the rate of the acetate infusion approximated maximum 
utilization $18,22,39,41]$. Acetate levels similar to the ones observed have not been shown to cause myocardial depression in stable chronic dialysis patients. On the other hand, Pagel et al. [28] observed no difference in postdialysis acetate levels in symptomatic patients having hypotensive periods or asymptomatic chronic patients. Therefore, a direct cardiodepressant effect of acetate cannot be excluded, in spite of relatively low peak levels. The effect of other ions, such as calcium, could be important. Ionised calcium measurements were not done. However, the calcium concentration of both dialysates were the same.

Alternatively, acetate dialysis could excert its cardiodepressant action indirectly by interfering with the acid-base metabolism 18 , 44]. We observed a significant drop in both arterial oxygen tension and carbon dioxide tension during acetate dialysis. During bicarbonate dialysis, we did not observe hypoxaemia. This is in contrast with the findings of Raja et al. [31]. The correction of the metabolic acidosis was comparable in both types of dialysis. However, in 5 patients there was an incomplete correction of the acidosis during acetate dialysis. A1. the aforementioned variables are known to interfere with optimum cardiac performance. Acidosis leads to cardiac depression as does hypoxaemia, whereas hypocapnia excerts a negative effect on coronary perfusion [11, 35]. Moreover, tissue hypoxaemia could be enhanced as a consequence of a shift of the oxyhaemoglobin dissociation curve to the left, due to hypocapnia [7]. In short, we conclude that the impairment in cardiac performance could be the result of a direct toxic effect of the acetate or of its interference with the acid-base metabolism.

It is tempting to speculate on the pathogenesis of the disturbance in the acid-base metabolism during acetate dialysis. The patient receives acetate, that must be metabolized in order to generate bicarbonate. At the same time, bicarbonate and carbondioxide are removed by the dialytic process as a consequence of high gradients between blood and dialysate [18]. In addition, $\mathrm{CO}_{2}$ is lost in regaining bicarbonate. Therefore $\mathrm{CO}_{2}$ is no longer available for ventilatory drive. The consequence of all these changes is a depression of the ventilation instead of a stimulation, as usualiy seen in metabolic acidosis. Indeed, Aurigemma et a1. [2], Dolan et a1. [10] and others [16, 24] observed a relative hypoventilation leading to hypoxaemia during acetate dialysis. Unfortunately, we did not record ventilation rates in 
our patients during this study, though we noticed the simultaneous development of hypoxaemia and hypocapnia. As demonstrated by the study of Tolchin et al. $\| 40\}$, these changes were more pronounced when singlepass haemodialysis was used. Tolchin et al. measured a decrease of $\mathrm{po}_{2}$ and of the minute ventilation volume in the first hour of the acetate dialysis, whereas the decrease of $\mathrm{pCO}_{2}$ was continuous though not significant during the whole dialysis. other factors, such as leucocyte-trapping in the lung and alveolar hypoventilation with ventilation perfusion imbalance, could be an additional explanation of the decrease of $\mathrm{po}_{2}$.

In summary, our study indicates that acetate haemodialysis leads to severe cardiovascular instability in critically ill patients as a consequence of impairment of cardiac performance. The complete absence of circulatory problems during bicarbonate dialysis makes the procedure a first choice in the difficult treatment of this group of patients. 
1. Alzawa $Y$, Ohmori $T$, Imai $K$, Nara $Y$, Matsuoka M, Hirasawa $Y$. Depressant action of acetate upon the human cardiovascular system. Clin Nephrol 8: 477-480 (1977).

2. Aurigerma NM, Feldman NT, Gottlieb M, Ingram RH, Lazarus JM, Lowrle EG. Arterial oxygenation during haemodialysis. New Engl J Med 297:871-873 (1977).

3. Baldamus $C_{A}$, Ernst $w$, Frei U, Koch $\mathrm{KM}$. Sympathetic and haemodynamic response to volume removal during different forms of renal replacement therapy. Nephron 31: 324-332 (1982).

4. Berk and Sampliner. Handbook of Critical Care. Little Brown, second edition (1982).

5. Borges MF, Fryd DS, Roga AA, Kjellstrand CM. Hypotension during acetate and bicarbonate dialysis in patients with acute renal Eailure. Am J Nephrol 1: 24-30 (1981).

6. Cannella $G$, Maiorca $R$. Acetate appearance curve in normotensive and hypotension-prone haemodialysis patients. Nephron 32: 269 (1982).

7. Cannella G, Maccagnola V, Giolani B, Maiorca R, Draghin E. The oxyhaemoglobin dissocation curve during acetate and bicarbonate dialysis. Nephron 32: 378 (1982).

8. Casciani CU, Gallucci MT, Mazzarella V, Menicocci D, Vancini C, Sprovieri L. Acetate dialysis concentrate and acid-base balance in patients maintained with chronic haemodialysis. Proc. ESAO III: 197 London $(1976)$.

9. Chen TS, Friedman HS, Smith AJ, Del Monte ML. Haemodynamic changes during haemodialysis: role of dialysate. Clin Nephrol 20: 190-196 (1983).

10. Dolan MG, Whipp $B J$, Davidson WD, Weitzmann RE, Wasserman $K$. Hypopnea associated with acetate haemodialysis: carbon dioxide flow dependent ventilation. N Engl J Med 305: 72-75 (1981).

11. Downing SE, Talner NS, Gardner TH. Cardiovascular responses to metabolic acidosis. Am J physiol 208: 237-242 (1965).

12. Everaets FM, Mikkers FEP, verheggen TPEM. Analytical isotachophoresis. J Chromat 119: 129-155 (1976).

13. Graefe U, Milutinovich J, Follette WC, Vizzo JE, Babb AL, Scribner BH. Less dialysis-induced morbidity and vascular instability with bicarbonate in dialysate. Ann Int Med 88: 332-336 (1978). 
14. Hampl H, Paeprer, Unger $V$, Fischer $C$, Resa $I$, Kessel M. Haemodynamic changes during haemodialysis, sequential ultrafiltration and haemofiltration. Kidney Int 18 : $583-588$ (1980).

15. Hsu CH, Swartz RD, Somemeyer MG, Raj A. Blcarbonate haenodialysis: influence on plasma refilling and haemodynamic stability. Nephron 38: 202-208 (1984).

16. Hunt JM, Rubin LJ, Chappell TR, Henrich WL. Acetate and bicarbonate haemodialysis cause equivalent hypoxia by different mechanisms. Am Soc Nephrol; abstract no 36: $48 \mathrm{Ba}$, washington (1983).

17. Iseki $K$, Onoyama $K$, Maeda $T$, shimamatsu $K$, Harada $A$ "Fyimi $S$, Omae T. Comparison of haemodynamics induced by conventional acetate haemodialysis, bicarbonate haemodialysis and ultrafiltration. Clin Nephrol 14:294-298 (1980).

18. Kaiser BA, Potter DE, Bryant RE, Vreman HJ, Weiner MW. Acid-base changes and acetate metabolisms during routine and high-efficiency haemodialysis in children. Kidney Int 19: 70-79 (1981),

19. Kirkendol PL, pearson JE, Bower JD, Holbert RD. Myocardial depressant effects of sodium acetate. Cardiovasc Res 12: 127-136 (1978).

20. Liang CS, Lowenstein JM. Metabolic control of the circulation. Effects of acetate and pyruvate. I Clin Invest 62 : 1029-1038 $(1978)$.

21. Mansel1 MA, Crowther A, Laker MF, Wing AJ. The effect of hyperacetatemia on cardiac output during regular haemodialysis. Clin Nephral 18: $130-134$ (1982).

22. Mansel1 MA "Nunan TO, Laker MF, Boon NA, Wing AJ, Incidence and significance of rising blood acetate levels during haemodialysis. Clin Nephrol 12: 22-25 (1979).

23. Mansell MA, Wing AJ. Acetate or bicarbonate for haemodialysis? Br Med J 287: 308-309 (1983).

24. Martin L. Hypoventilation without elevated carbon dioxide tension. Chest 77: $720(1980)$.

25. Mehta BR, Almad M, Dubose TD. Effect of acetate and bicarbonate haemodialysis on left ventricular contractility in patients with depressed cardiac function. Am Soc Nephrol, abstract no 36: 51 a, Washington (1983). 
26. Milutinovic J. Bekheit $S$, Lapp $L$. Myocardial performance during dialysis with dialysate containing acetate, bicarbonate and sequential ultrafiltration and dialysis. Am Soc Nephrol, abstract no 13: 47a, Boston (1980).

27. Novello A, Kelsch RC, Easterling RE. Acetate intolerance during haemodialysis. Clin Mephrol 5: 29-33 (1976).

28. Pagel MD, Ahmad S, Vizzo JE, Scribner BH. Acetate and bicarbonate fluctuations and acetate intolerance during dialysis. Kidney Int 21: $513-518(1982)$.

29. Posen GA, Mikhael R. Correction of hypotension early in dialysis by substitution of acetate with bicarbonate. Am Soc Nephrol, abstract no 13: 49a, Boston (1980).

30. Raja RM, Henriquez M, Kramer MS, Rosenbaum JL. Improved dialysis tolerance using ready sorbent system with bicarbonate dialysate in critically ill patients. Dial Transpl 8: 241-244 (1979).

31. Raja RM, Kramer MS, Alvis R, Delosangeles A. Haemodialysis with varying dialysate bicarbonate and constant sodium concentration. Amer Soc Nephrol, abstract no 70: 53a, Washington (1983).

32. Ruder MA, Alpert ME, Van stone J, Selman MR. Comparative effects of haemodialysis with acetate versus bicarbonate on left ventricular function. Amer Soc Mephrol, abstract no 36: 55a, Washington (1983).

33. Salvadeo A, Cantaluppi A, Segagni S, Casati S, Galli F, Graziani G, Poggio F, Bonucchi D, Cittorio A, Piazza V, Ponticelli C. Multicentric experience on prevention of vascular instability and dialytic intolerance by bicarbonate single pass or recirculating haemodialysis. 19th EDTA (abstract): p 124, Madrid (1981).

34. Samar RE. Bicarbonate and acetate in haemodialysis. Comtemporary Dialysis, August: 10 , September: (1981).

35. Scheuer $J$. The effects of respiratory and metabolic alkalosis on coronary flow, haemodynamics and myocardial carbohydrate metabolism. Cardiologia 52: 275-286 (1968).

36. Scribner BH. Substitution of biarbonate for acetate in the dialysate for care of a critically ill patient. Dial Transpl 6: 26 $(1977)$.

37. Shaldon S, Baldamus CA, Koch KM, Lysaght MJ. of sodium, symptomatology and sylogism. Blood Purification 1: 16-24 (1983). 
38. Van stone JC, cook $J$. The effect of bicarbonate dialysate in stable chronic haenodialysis patients. Dial Transpl 8: 703 (1979).

39. Tolchin N. Acetate metabolism and high efficiency haemodialysis. Intern J Artif Organs 2: $1-3$ (1979).

40. Tolchin N, Roberts JL, Lewis EJ. Respiratory gasexchange by high efficiency hemodialyzers. Nephron 21: 137-145 (1978).

41. Tolchin $N$, Roberts JL, Hayashi J, Lewis EJ, Metabolic conseguences of high mass-transfer haemodialysis. Kidney Int 11: $366-378(1977)$.

42. Vincent JL, Vanherweghem JL, Degaute JP, Berré J, Dufaye P, Kahn R.J. Acetate-induced myoardial depression during haemodialysis for acute renal failure. Kidney Int 22: 653-657 (1982).

43. Weiner $M W$. Acetate dialysate versus bicarbonate dialysate. Panel Conference. Trans Am Soc Artif Int Organs 28: 661-662 (1982).

44. Yamakawa M, Yamamoto $T$, Kishimoto T, Mizutami $Y$, Yatsuboshi M, Nishitani H, Hirata $S$, Horiuchi N, Maekawa M. Serum levels of acetate and TCA-cycle intermediates during haemadialysis in relation to symptoms. Nephron 32: 155-161 (1982). 


\section{CHAPTER VT}

INFLUENCE OF LEFT VENTRICULAR PUNCTION ON CHANGES OF PLASMA VOLUME DURING ACETATE AND BICARBONATE DIALYSIS

K.M.L. Leunissen, E.C. Cheriex, J. Janssen, G.J.J. Teule, J.M.V. Mooy, M. Ramentol and J.P. van Hooff

Department of Internal Medicine, Cardiology and Nuclear Medicine University Hospital Maastricht. The Netherlands 
The effect of left ventricular function on changes of plasma volune during acetate (AC-D) and bicarbonate (BC-D) dialysis was studied in stable chronic dialysis patients. Preservation of plasma volume in patients with a normal left ventricular function (mean circumferential fiber shortening velocity [VCF] $\geq 1 \mathrm{circ/sec}$ was significantly less during the first hour of $A C-D$ than during $B C-D$. However in patients with impaired left ventricular function (VcF " 1 circ/sec) the decrease of plasma volume was even more pronounced during Ac-D as compared to BC-D.

This resulted in a decreased ultrafiltration volume and haemodynamic instability in these patients during AC-D. The VCF increased during $A C-D$ and $B C-D$ in patients with a normal left ventricular function, whereas in patients with impaired left ventricular function veF increased only during BC-D. In conclusion, in patients with an impaired left ventricular function, dialysis using bicarbonate dialysate is preferable to the use of acetate dialysate.

\section{Introduction}

Haemodynamic instability associated with haemodialysis has been attributed to different factors; the buffer substrate used [1-3], the composition of the dialysate [4-5], the ultrafiltration rate and the cardiovascular state of the patient $[2,7 \mathbb{1}$. In patients with acute renal fallure acetate dialysis $(A C-D)$ has been shown to cause an unstable haemodynamic state, whereas during bicarbonate dialysis (BC-D) a more stable haemodynamic state has been observed [8-9]. A significant decrease of left ventricular stroke work index (LVSWI) has been measured during AC-D. Decrease of LVSWI was only mild during BC-D [8]. These findings have been related to hypoxaemia, hypocapnia and incomplete correction of acidosis during AC-D [8, 10-11]. In our previous study however the changes of cardiac filling pressures did not differ significantly between $A C-D$ and $B C-D$ although ultrafiltration rate was comparable in each pair of dialysis [8]. Differences in plasma volume preservation (PVP) could be the explanation for this phenomenon [12-13]. The rate of fluid mobilization from the extravascular to the intravascular compartment was different in AC-D compared to BC-D and 
was not related to changes of asmolality and colloid oncotic pressure [14]. This "plasma refilling rate" is related to the capillary starling equilibrium [15]. Acetate could interfere with this equilibrium due to vasodilatation [16] and cardiodepression [3, 17]. Especially in patients with a compromised cardiovascular state these effects of acetate could be more pronounced, leading to an impairement of pVP during Ac-D.

The aim of this study was to investigate the effect of left ventricular function on PVP during AC-D and BC-D in chronic haemodialysis patients.

\section{Patients and methods}

Stable chronic haemodialysis patients were eligible for the study when a echocardiography could be reproducably performed on them. Patients with an important valvular dysfunction and left ventricular aneurysm were excluded from the study. Thirteen patients were induced. Patients were divided in two groups on the basis of the echocardiographic parameters. Group $I$ included patients with a normal left ventricular function, defined as having a mean circumferential fiber shortening (VCF) of $\geq 1 \mathrm{circ} / \mathrm{sec}(n=9)$ and group II patients with a compromised left ventricular function, defined as a VCF \& 1 circ/sec $(n=4)$. Mean age was 49 years. Patients were maintained on unchanged therapy regimens throughout the study.

During two consecutive weeks two sessions were performed, respectively 4 hours $A C-D$ and 4 hours BC-D. Both dialysates contained the following ions (meq/1): sodium 140, potassium 2,0, calcium 3,2, magnesium 1. The bicarbonate dialysate contained in addition (meq/1): bicarbonate 33 , chloride 110,2 and acetate 3 , whereas the acetate dialysate contained no bicarbonate, chloride 110,2 and acetate $35 \mathrm{meq} / 1$. The same delivery system (Gambro AK 10 ) and artificial kidney (Gambro 120 M) were used. The blood flow was $200 \mathrm{ml} / \mathrm{min}$, the dialysate flow $500 \mathrm{ml} / \mathrm{min}$. The "dry-weight" and the ultrafiltration rate were constant in each pair of dialyses. Before and after the dialysis patients were studied by means of echocardiography (M-mode and 2D-mode), with measurement of circumferential fiber shortening velocity [18-19] and end systolic left ventricular wall stress (ESS) $[20]$. Before and at $15 \mathrm{~min}, 30 \mathrm{~min}, 1,2$, 3 and 4 hours during dialysis heart rate and blood pressure were 
measured and the amount of ultrafiltration fluid (VUF) was recorded. plasma volume and red cell volume were measured before dialysis according to the radioiodinated serum albumine (RISA) method [21]. Changes of plasma volume were calculated at the above mentioned intervals using a serial hematocrit method [22]. The total amount of blood witharaw during each study was $25 \mathrm{ml}$. Blood loss in the dialyser was nitill.

Initial red blood cell ( $R B C$ ) volume was calculated as:

RBC volume $=\mathbb{P V}$ (Hcto/1 - HCto $)$, where $P V_{0}$ is the initial plasma volume and $H t_{O}$ the initial haematocrit.

plasma volume during dialysis was calculated as:

$\mathrm{PV}_{\mathrm{t}}=\mathrm{RBC}$ volume $\left(1-\mathrm{HCt}_{\mathrm{t}} / \mathrm{HCt}_{t}\right)$, where PV $\mathrm{t}$ and HCt $\mathrm{H}_{\mathrm{t}}$ are the plasma volume and the haematocrit, respectively at time $t$.

The extra vascular fluid mobilization (WFM) was calculated as the difference between VUF and change in plasma volume at time $t$ :

$V F M=V U F-\left(P V_{0}-P V_{t}\right)$.

VFM/VUF is the cumulative fluid mobilization in relation to total ultrafiltration volume.

Osmolality was determined by freezing point depression at the same intervals as described above. Before and after dialysis colloid oncotic pressure was measured and total $\mathrm{CO}_{2}$, according to the method of thermic conductivity.

All data are expressed as t mean SEM. Statistical analysis was done using the paired t-test. At a $p$ value " 0,05 the differences were regarded as statistically significant.

\section{Results}

A significant difference in PVP was measured in the first hour AC-D compared to BC-D in group I (figure 11). In group II PVP was significantly lower during the first two hours of AC-D (figure 2). The amount of ultrafiltrate at the end of both dialysis in group I did not differ significantly. AC-D: $1393 \pm 274 \mathrm{ml}$; BC-D: $1620 \pm 300 \mathrm{ml}$. However in group II there was a significant difference in net ultrafiltration volume in group II during AC-D $(1450 \pm 180)$ in comparison with BC-D $(2350 \pm 380 \mathrm{~m} I)(p<0.01)$. 
The initial MAP in group I was: AC-D: $106.1 \pm 8.2 ; B C-D \quad 99.2 \pm 7.1$ matig (NS) and in group II: AC-D: $99.0 \pm 9.9 ; \mathrm{BC}-D: 90.7 \pm 10.4 \mathrm{~mm} / \mathrm{Hg}$ (NS).

A significant decrease of MAP was observed during $A C-D$ compared to BC-D in both studied groups (figure 1 and 2 ). In group II a decrease of MAP below $60 \mathrm{~mm}$ ing was observed during the first hour of AC-D in three patients, which forced us to stop ultrafiltration for 1 to 2 hours.

The initial HR in group $I$ was: $A C-D: 73 \pm 4.8 ; B C-D: 72.1 \pm 3.7 \mathrm{~b} / \mathrm{min}$ and in group II: AC-D: $80 \pm 5.1 ; \mathrm{BC}-\mathrm{D}: 83.7 \pm 6.1 \mathrm{~b} / \mathrm{min}$. In both groups HR increased significantly during AC-D as compared to BC-D (figure 1, 2).
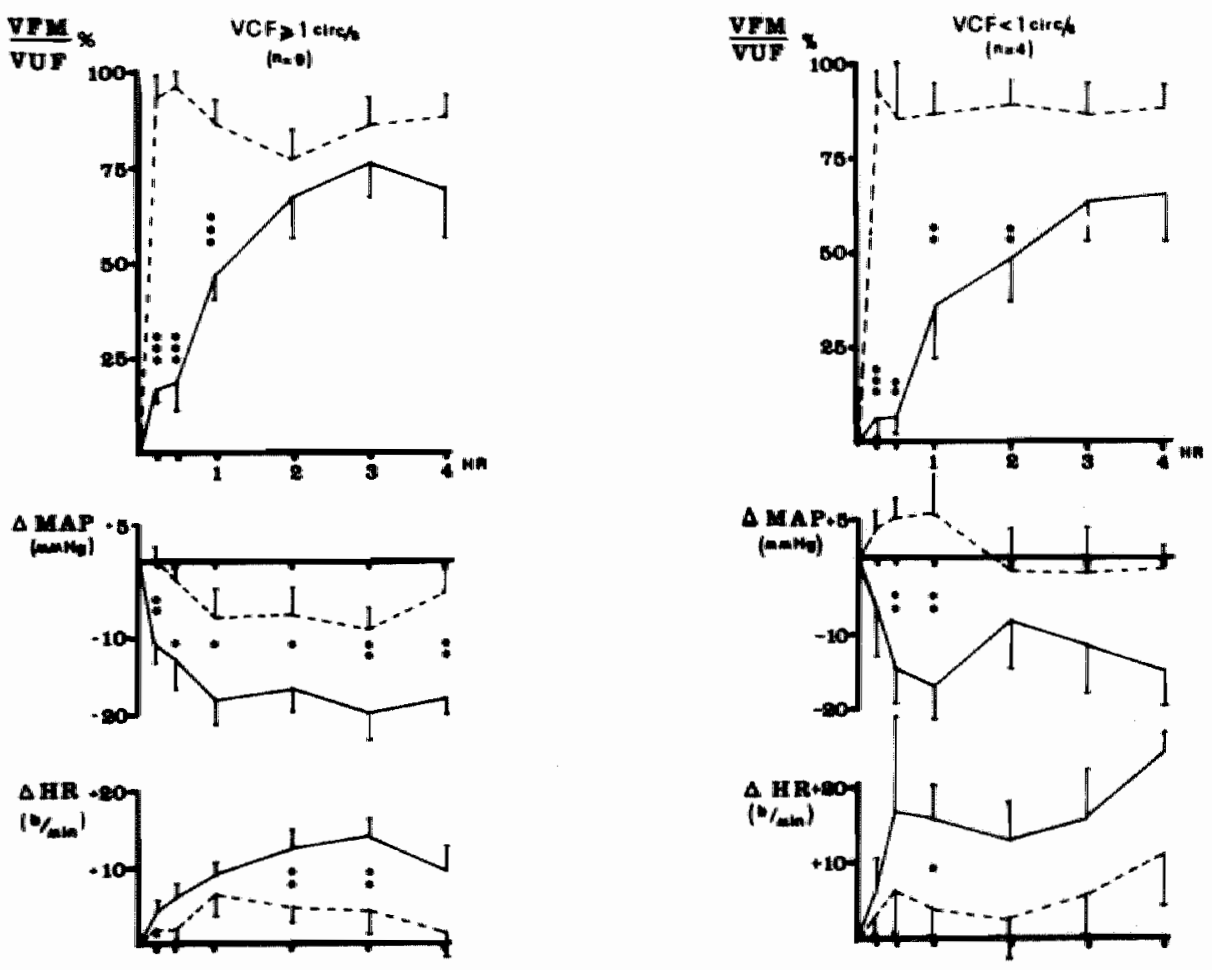

Eiqure 1+2:

Plasma volume preservation in patients with a VCF 21 circ/sec (left side) and in patients with a VCF ( 1 circ/sec (right side).

Cumulated fluid mobilization (VFM) relative to ultrafiltration volume (vUF).

$\triangle M A P$ : changes of mean arterial pressure as compared to the initial value before dialysis

$\triangle H R$ : changes of heart rate as compared to the initial value before dialysis

AC-D: solid lines; $B C-D$ : dotted lines.

Means \pm SEM are indicated.

$* p<0,05 ; * * p<0,01, * * * p<0,001$ 
The circumferential fiber shortening velocity (VcF) increased significantly during respectively $A C-D$ and $B C-d$ in group I: from $1.06 \pm 0.07$ to $1.43 \pm 0.10 \mathrm{circ} / \mathrm{sec}(p<0.01)$ and from $1.19 \pm 0.10$ to $1.4 \pm 0.12$ (p 0.01$)$ respectively. In group II there was only a significant increase of VCF during $B C-D$ (VCF during $A C-D$ : from $0 . B 7 \pm 0.16$ to $1.01 \pm 0.22$ [NS]; VCF during BC-D: from $0.63 \pm 0.14$ to $0.89 \pm 0.14$ [p<0.05]). The end systolic stress (ESS) decreased in group $I: A C-D: 65.7 \pm 8.2$ versus $54.4 \pm 9.3(\mathrm{p}<0.01) ; \mathrm{BC}-\mathrm{D}: 65.1 \pm 7.2$ versus $53.7 \pm 6.4 \times 10^{3}$ dyne/cm2 (p<0.01), in group II: Ac-D: $111.1 \pm 11.4$ to $88.4 \pm 12.5$ (p<0.05); BC-D: $102.1 \pm 14.2$ to $84.3 \pm 9.5 \times 10^{3}$ dyne $/ \mathrm{cm}^{2}$ (p<0.05).

Changes of osmolality are illustrated in figure 3 . Changes of osmolality reached no statistical significance during $A C-D$ or Bc-D. The colloid oncotic pressure changes of group I and II were not significantly different between AC-D and BC-D. In group I colloid oncotic pressure increased during Ac-D from $23.2 \pm 1.4$ to $25.9 \pm 2.8 \mathrm{~mm} \mathrm{Hg}$ and during BC-D from $23.5 \pm 1.6$ to $25.0 \pm 4.3 \mathrm{mmHg}$. In group II colloid oncotic pressure increased during AC-D from $23.2 \pm 5$ to $24.8 \pm 3.6$ and during $\mathrm{BC}-\mathrm{D}$ from $22.5 \pm 2.4$ to $24.2 \pm 2.8 \mathrm{mmHg}$. Total $\mathrm{CO}_{2}$ increased during AC-D from $19.6 \pm 2.4$ to $21.7 \pm 3.4 \mathrm{mmol} / 1$ (NS) and during $B C-D$ from $20.0 \pm 2.1$ to $26.7 \pm 1.6(p<0.01) \mathrm{mmol} / 1$.

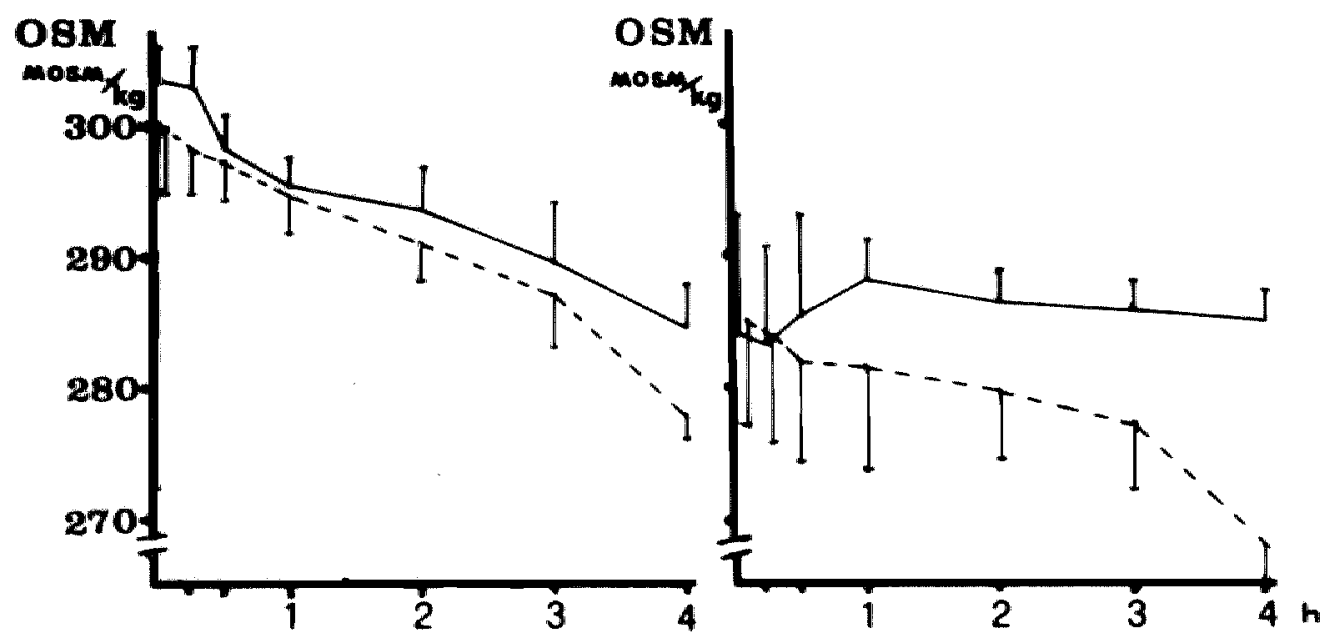

\section{Fiqure 3:}

Changes of osmollality during AC-D (solid lines) and $B C-D$ (dotted line) in patients with a $\mathrm{VCF} \geq 1 \mathrm{circ} / \mathrm{sec}$ (left picture) and in patients with a VCF \& $1 \mathrm{circ} / \mathrm{sec}$ (right picture). 
In critically ill patients, in whom dialysis is indicated, Bc-D should be the first choice in the treatment of renal insufficiency [8-9]. Whether BC-D is also indicated in patients undergoing chronic stable haemodialysis is still a matter of debate [23-24]. Acetate has been associated with an unstable cardiovasculas state during haemodialysis because of its vasodilating $[1,16,23]$ and cardiodepressive effects [3, 8-9, 17]. However many studies performed during chronic dialysis could not confirm cardiovascular instability during AC-D [23, 25-26]. of interest is the study of Hsu et al [14], who reported a difference in PVP during AC-D with low sodium concentration compared to BC-D with low sodium concentration, showing no statistically significant difference in PVP between low sodium bicarbonate versus high sodium $A C-D$. We studied PVP during high sodium $A C-D$ and high sodium $B C-D$ in relation to left ventricular function. In patients with normal left ventricular function PVP was only impaired during the first hour of $A C-D$, while in patients with an impaired left ventricular function a decreased PVP was observed in the first two hours of AC-D. Hypotension forced us to stop ultrafiltration, leading to significant decrease of the amount of ultrafiltrate during AC-D compared to BC-D. Neither the osmolality changes nor the changes of colloid oncotic pressure could account for these differences in PVP. Osmolality did not change during $A C-D$ in patients with impaired left ventricular function (figure 3 ) because of haemoconcentration due to insufficient fluid mobilization from the extravascular compartment.

During $A C-D$ compared to $B C-D$ the MAP decreased and the HR increased significantly in both groups. These changes are caused by the vasodilatory effect of acetate and the decreased PVP in the group of patients with impaired left ventricular function. The vcF increased significantly in patients with a normal left ventricular function during $A C-D$ as well as during $B C-D$. In the group of patients with a compromised left ventricular function only a significant increase of VCF during BC-D was observed. The increase of VCF is partially due to an increase of heart rate. The end systolic stress is afterload dependent and decreased significantly during $A C-D$ as well as during $B C-D$ partially due to the decrease of systolic blood pressure. These findings are not in agreement with the results of Ruder et al [2], who 
observed a significant increase of VCF during BC-D as compared to AC-D in patients with a normal as well as a compromised left ventricular function. They observed an increase of VoF during AC-D only in patients with a compromised left ventricular function and not in patients with a normal left ventricular function.

It is tempting to speculate on the explanation of the difference in pvp in comparing $A C-D$ and $B C-D$. Acetate results in arteriolar vasodilatation $[1,16,23]$, which influences the perfusion of the capillary beds increasing fluid spill from the capillaries into the interstitium, disregulating the capillary starling equilibrium [15, 27281. A compromised cardiac function with high cardiac filling pressures will result in an increased hydrostatic pressure at the venule side of the capillaries also disregulating the capillary starling equilibrium [15, 27-28]. Acetate could also interfere with this starling equilibrium by inducing an increased release of Interleukin-I, especially in combination with a cuprophane membrane [29]. InterleukinI can induce pathological leasions of endothelial cells, which could increase capillary permeability [30]. These effects of acetate could result in a decreased fluid mobilization from the extravascular compartments into the vascular compartments during dialysis and ultrafiltration.

In conclusion, PVP is strongly impaired during high sodium Ac-d in patients with a compromised left ventricular function, whereas during high sodium BC-D only a very mild decrease of plasma refilling rate was observed. Impairment of plasma volume preservation leads to haemodynamic instability. Chronic dialysis patients should therefore be studied echocardiographically to investigate left ventricular function. In chronic dialysis patients with an impaired cardiac function BC-D should be the treatment of choice. 
1. Iseki $K$, Onoyama $K$, Maeda $T$ et al. Comparison of haemodynamics induced by conventional acetate haemodialysis, bicarbonate haemodialysis and ultrafiltration. Clin Nephrol 14: 294-298 (1980).

2. Ruder MA, Alpert MA, van Stone J et al. Comparative effects of acetate and bicarbonate haemodialysis on left ventricular function. Kidn Int $27: 768-773$ (1985).

3. Aizawa $Y$, Ohmori $T$, Imai $K$, Nara $Y$, Matsuoka M, Hirasawa $Y$. Depressant action of acetate upon the human cardiovascular system. Clin Nephrol 8: 477-480 (1977).

4. Swartz RD, Somermeyer MG, Hsu CH. Preservation of plasma volume during haemodialysis depends on dialysate asmolality. Am J Nephrol 2: $189-194(1982)$.

5. Baldamus A, Ernst W, Frei U, Koch KM. Sympathetic and haemodynamic response to volume removal during different forms of renal replacement therapy. Nephron 31: 324-332 (1982).

6. Rodriguez $M$, Pederson JA, Uach F. Effect of dialysis and ultrafiltration on osmolality, colloid osmotic pressure and vascular refilling rate. Kidn Int 28: 808-813 (1985).

7. Metha SR, Almad M, Dubose TD. Effect of acetate and bicarbonate haemodialysis on left ventricular contractility in patients with depressed cardiac function. Am Soc Nephrol washington, Abstract 36: 51 a $(1983)$.

8. Leunissen KML, Hoorntje SJ, Fiers HA, Dekkers WT, Mulder AW. Acetate versus bicarbonate haemodialysis in critically ill patients. Nephron 42: $146-151$ (1986).

9. Vincent JL, Vanherweghem JL, Degaute JP, Berré J, Dufaye Ph, Kahn RJ. Acetate induced myocardial depression during haemadialysis for acute renal failure. Kidn Int $22: 653-657$ (1982).

10. Tolchin N, Roberts JL, Lewis EJ. Respiratory gas exchange by high effeciency haemodialyzers. Nephron 21: 137-145 (1978).

11. Dolan MG, Whipp BJ, Davidson WD, weitzman RE, wasserman $K$. Hypopnea associated with acetate haemodialysis: Carbon dioxide-flow dependent ventilation. New Eng $J$ Med 305: 72-75 (1981). 
12. Chaignon $M$, Chen WT, Tarazi RC, Bravo EL, Nakamoto $S$. Effect of haenodialysis on blood volume distribution and cardiac output. Hypertension 3: $327-332(1981)$.

13. Kimura G, van stone JC, Bauer JH. Model prediction of plasma volume change induced by haemodialysis. J Lab Clin Med 104: $932-938(1984)$.

14. HSU CH, Swartz RD, Somermeyer MG, Raj A. Bicarbonate haemodialysis: Influence on plasma refilling and haemodynamic stability. Nephron 38: 202-208 (1984).

15. Rushmer RF. Cardiovascular dynamics. W.B. Saunders Company, 3rd Edition, $19-25$ (1970).

16. Pagel MD, Almad S, Vizzo JE, Scribner BH. Acetate and bicarbonate fluctuations and acetate intolerance during dialysis. Kidn Int 21: $513-518(1982)$.

17. Kirkendol PL. Pearson JE, Bower JD, Holbert RD. Myocardial depressant effects of sodium acetate. Cardiovascul Res 12: $127-136$ (1978).

18. Drïleke $T$, Zingraff $J$, Boudier $L$, Baubion $N$, Gambine $D$, Le Pailleur C. Noninvasive exploration of myocardial function in haemodialysis patients. Contr Nephrol (Karger Basel) 41: 280-283 (1984).

19. Quinones MA, Gaasch WH, Alexander GK. Influence of acute changes of preload, afterload, contractile state and heart rate on ejection and isovolumic indices of myocardial contractility in man. Circulation 53: 293 (1976).

20. Reichek $N$, Wilson J, St John Sutton M, Plappert TA, Goldberg S, Hirshfeld JW. Noninvasive determination of left ventricular end-systolic stress: Validation of the method and initial application. Circulation 65: 99-108 (1982).

21. Reyes J, Carey J, Mosses D, Beierwaltes $W$. Manual of nuclear medicine procedures. CRS press, Cleveland, second edition, 95-98 $(1973)$

22. Tarazi RC, Melsher HJ, Dustan HP, Frolich ED. Plasma volume changes with upright tilt: studies in hypertension and in syncope. J Appl Physiol 28: 121-126 (1970).

23. Mansell MA, Crowther A, Laker MF, wing AJ. The effect of hyperacetatemia on cardiac output during regular haemodialysis. Clin Nephrol 18: $130-134$ (1982). 
24. Mansell MA, Wing AJ. Acetate or bicarbonate for haemodialysis? Br Med J 287: 308-309 (1983).

25. Mansell MA, Nunan TO, Laker MF, Boon NA, wing $A J$. Incidence and signifance of rising blood acetate levels during haemodialysis. Clin Nephrol 12: $22-25$ (1979).

26. Kjellstrand CM, Pru $C$, Borges HF. Acetate versus bicarbonate dialysis: A review of biochemical and clinical side effects. In Schreiner, Wichester, Controversies in Nephrology, 1000 , Arlington), 3: $920107(1981)$.

27. Sjöstrand T. Volume and distribution of blood and their significance in regulating the circulation. Physiol Rev 33: $202-228(1953)$.

28. Sodeman WA. Pathologic Physiology: Mechanisms of Disease. Philadelphia, w. B. Saunders Company (1956).

29. Bingel $M$, Lonnemann $G$, Koch $K M$, Dinarello $C A$, Shaldon $S$. Enhancement of in vitro human Interleukin-I production by sodium acetate. Lancet i: 14-16 (1987).

30. Dinarello CA. Interleukin-I: Its multiple biological effects and its association with haemodialysis. Blood Purif 6: 164-172 (1988). 
IONIZED PLASMA CALCIUM pLAYS A PIVOTAL ROLE IN CONTROLLING BLOOD PRESSURE DURING HAEMODTALYSIS

K.M.L. Leunissen, B.W. van den Berg, J.P. van Hooff

Department of Internal Medicine

University Hospital Maastricht, The Netherlands 
The influences of dialysate bicarbonate concentration on ionized plasma calcium as well as on haemodynamics have been studied prospectively. In 3 consecutive weeks 7 chronic patients were dialysed with a dialysate containing low bicarbonate $(30 \mathrm{meq} / 1)$, medium bicarbonate $(35 \mathrm{meq} / 1)$ and high bicarbonate $(39.5 \mathrm{meq} / 1)$ respectively. Notwithstanding the same considerable influx of calcium during high, medium and low bicarbonate dialysis, a significant increase of ionized calcium from 1.09 to $1.41 \mathrm{mmol} / \mathrm{I}$ was observed during low bicarbonate dialysis only. During medium and high bicarbonate no significant increase of ionized calcium occurred due to a rapid change of acidosis to alkalosis. During low bicarbonate mean arterial pressure remained almost the same, while during medium and high bicarbonate a significant decrease of mean arterial pressure was observed. In conclusion, during dialysis an increasing ionized plasma calcium was counteracting the negative effect of fluid removal on blood pressure. Results of this study underlines the pivotal role of ionized plasma calcium for regulation of blood pressure.

\section{Introduction}

One of the aims of haemodialysis is removal of superfluous extracellular volume, often resulting in a decreasing blood pressure. Hypotension is very unpleasant for the patient and makes dialysis inefficient. We have shown that critically ill patients and patients with a compromised left ventricular function are much more prone for developing hypotension, and that dialysates containing acetate gives a higher incidence of periods with hypotension, compared to dialysate containing bicarbonate [1-2]. Furthermore it has been shown that an increasing ionized plasma calcium might result in an improved haemodynamic stability $[3]$. Changes of ionized calcium concentrations are related to changes of $\mathrm{pH}$ [4]. During dialysis correction of metabolic acidosis will occur through influx of buffer substrates, such as bicarbonate. Rate of influx of buffer substrate will determine speed of correction of $\mathrm{pH}$. There are delivery systems capable of generating various concentrations of bicarbonate. Therefore a prospective study was performed to the influence of height of bicarbonate concentration on ionized plasma calcium as well as on haemodynamics. 
Seven stable chronic haemodialysis patients with a mean length of time on haemodialysis of $21.6 \pm 13.9$ months and mean age of $68.0 \pm 2.0$ years volunteered for the study. Cause of renal fallure was analgetic nephropathy $(n=2)$, chronic glomerulonephritis $(n=3)$, pyelonephritis $(n=1)$ and diabetic nephropathy $(n=1)$.

A11 patients were treated with phosphate binders and activated vitamin D. Prior to dialysis phosphate concentration was $1.57 \pm 0.17 \mathrm{mmol} / 1$; calcium concentration (total) $2.38 \pm 0.06 \mathrm{mmol} / 1$; albumen concentration $33.9 \pm 2.1 \mathrm{~g} / 1$; alkaline phosphatase $85.7 \pm 22.1 \mathrm{~W} / 1 \mathrm{l}(\mathrm{n}=30-125 \mathrm{U} / \mathrm{l})$; $\mathrm{PTH}$ $11.3 \pm 7.3 \mathrm{pmol} / 1(\mathrm{n}=0.5-15 \mathrm{pmol} / 1)$ according to a immunoradiometric assay with the use of labled antibodies.

In three consecutive weeks patients were treated with either low, medium or high bicarbonate respectively. All 3 dialysates contained the same calcium concentration: 1.75 mol/1. Compositions of dialysates are depicted in table $I$.

\section{Table I:}

Composition of the dialysates used in this study.

bicarbonate

low medium high

\begin{tabular}{llll}
\hline $\mathrm{pH}$ & 7.00 & 7.25 & 7.40
\end{tabular}

Bicarbonate meg/1

30.00

35.00

39.50

Acetate meg/1

3.00

3.00

3.00

Calcium meg/1

3.50

3.50

3.50

Sodium meq/1

138.00

140.00

142.00

Potassium meg/1

2.20

2.00

2.20

Magnesium meg/1

1.00

1.00

1.00

Chloride meq/1

111.70

108.50

106.20 
The same dialyzer Gambro GF 120 in and delivery system Hospal Monitral s were used. During dialyses blood flow and dialysate flow were kept constant on $200 \mathrm{ml} / \mathrm{min}$ and $500 \mathrm{ml} / \mathrm{min}$ respectively. During various dialyses in each individual patient ultrafiltration rate was kept constant. Patients were ultrafiltrated to their dry weight.

The net callium influx was calculated according to the formula: $-3.07+75.3$ (CD.D - Cp.0) $+0.0432 \mathrm{Vp}-8.15 \mathrm{PpO}[5]$.

$\mathrm{CD} . \mathrm{O}=$ inflow dialysate calcium concentration mol/1, Cp.O = inflow plasma ultrafiltrable calcium concentration mal/1, ppo = plasma phosphate concentration, $\mathrm{Vp}=$ plasma volume flow $(\mathrm{ml} / \mathrm{min})$, influx expressed in $\mu$ mollmin.

Before dialysis and at 1,2 and 3 hours ionized calcium, potassium, sodium, and total $\mathrm{CO}_{2}$ were raeasured in whole blood. At the bed side ionized calcium, potassium and sodium were measured by an ion specific electrode (Fresenius Ionometer EF). Before each measurement electrodes were calibrated. Furthermore at the start a test measurement with ionotest (with a known electrolyte composition) was performed. Total $\mathrm{CO}_{2}$ was measured according to the method of thermic conductivity.

Before dialysis and during dialysis each half hour, heart rate (HR), blood pressure (MAP) and ultrafiltration volume was recorded.

The data on individual patients were analyzed with student's paired t-test. A p-value of $<0.05$ was considered significant and all results are reported as means $\pm S D$. Correlation coefficient was determined by the Pearson's test.

\section{Results}

During low, medium and high BC-D computed calcium influx was the same and amounted $26.9 \pm 3,3,25.3 \pm 9.7$ and $24.4 \pm 3.1 \quad \mu \mathrm{mol} / \mathrm{min}$ respectively.

During low BC-D ionized Calcium increased significantly from 1.09 to 1.41 mmol/1 (figure 1), while during high and medium BC-D no significant increase of ionized calcium was observed (figure 1). After 1, 2 and 3 hours of dialysis ionized calcium was significantly higher (p<0.001) during low BC-D compared to high and medium BC-D (figure 1). During low, medium and high $\mathrm{BC}-\mathrm{D}$ total $\mathrm{CO}_{2}$ increased significantly (figure 1). After 1,2 and 3 hours of dialysis total $\mathrm{CO} 2$ was significantly higher during medium and high BC-D compared to low BC-D 
$(t=1,2,3$ hours resp. p<0.05, $p \times 0.01, p<0.001)$ (figure 1). There was a significant inverse correlation between the changes of ionized calcium and the changes of total $\mathrm{CO}_{2}(r=-0.70, \mathrm{p}<0.001)$.
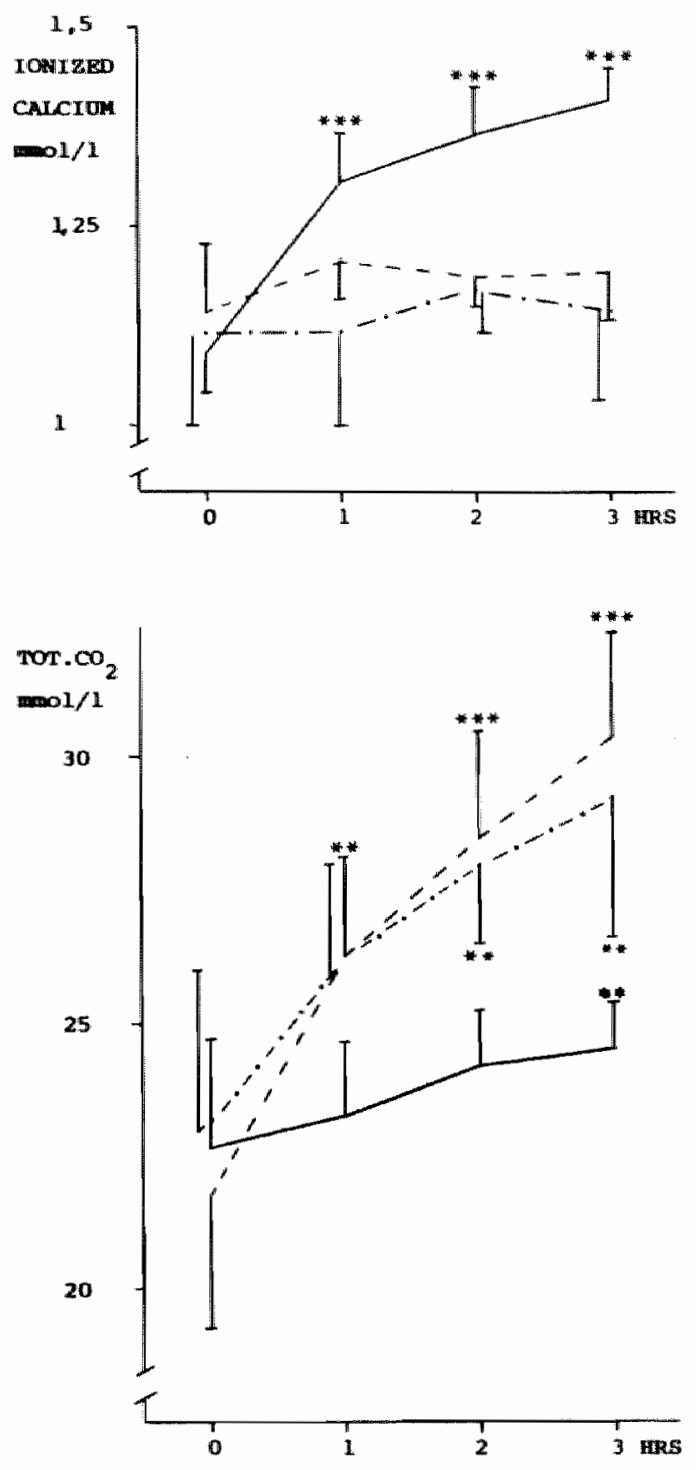

Fiqure 1:

Profiles of ionized calcium and totall $\mathrm{CO} 2$ during the various bicarbonate dialyses.

| I L l low bicarbanate dialysis

$\mid-\ldots . .-1$ : medium bicarbonate dialysis

$\mid-\ldots-1$ : high bicarbonate dialysis

Means \pm SD are indicated: *: pr0.05, **: p<0.01,**: p<0.001 

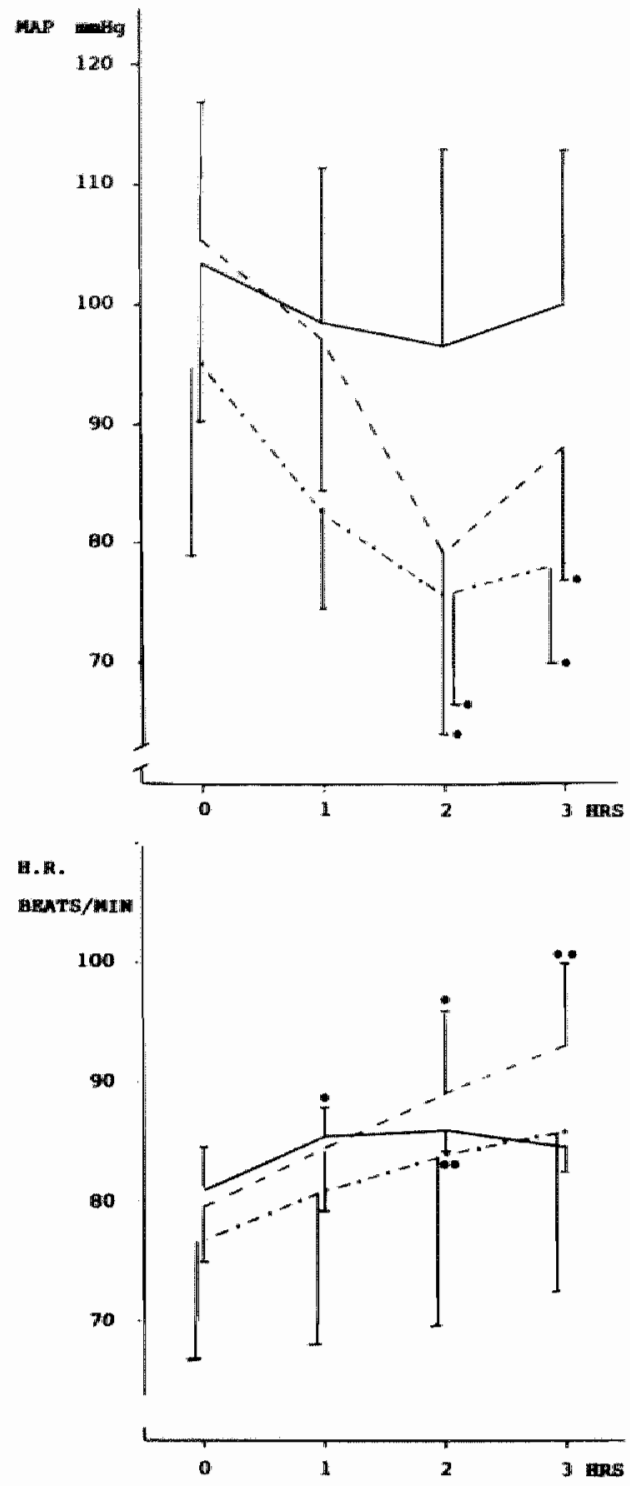

\section{Eicure 2:}

Haemodynamic profiles during the various bicarbonate dialyses.

| I l low bicarbonate dialysis

$|-\ldots . .-| \mid$ : medium bicarbonate dialysis

$|\ldots \ldots . . . .-|$ : high bicarbonate dialysis

MeanstSD are indicated: $\because p<0.05, \cdots: p<0.02$

No significant increase of sodium occurred in either group: low BC-D $138.2 \pm 2.5$ to $139.0 \pm 2.1$, medium $\mathrm{BC}-\mathrm{D} 135.5 \pm 3.0$ to $137.5 \pm 1.7$ and high BC-D $138.1 \pm 4.0$ to $140.0 \pm 1.0 \mathrm{mmol} / 1$.

Serum potassium concentration decreased significantly in each group: 
Iow BC-D from $4.96 \pm 0.57$ to $4.06 \pm 0.37$ (p<0.02), medium BC-D from $4.56 \pm 0.60$ to $3.51 \pm 0.3(\mathrm{p} \times 0.01)$ and high $B C-D$ from $4.86 \pm 0.49$ to $3.50 \pm 0.28$ mmol/1 (p<0.001).

During low, medium and high BC-D ultrafiltration volume was the same and amounted $1.20 \pm 0.81,1.16 \pm 0.71$ and $1.12 \pm 0.61$ (NS) respectively. During medium and high BC-D MAP decreased significantly, whereas during Low BC-D MAP remained almost the same (figure 2). During low and high BC-D HR increased significantly. During medium BC-D the increase of HR was not statistically significant (figure 2 ).

\section{Discussion}

Notwithstanding the same considerable influx of calcium during high, medium and low $\mathrm{BC}-\mathrm{D}$, a significant increase of ionized calcium from 1.09 to $1.41 \mathrm{mmol} / 1$ was observed during low BC-D only.

During medium and high BC-D no significant increase of ionized calcium occurred due to a rapid change of acidosis to alkalosis. A rapid increase of $\mathrm{pH}$ will counteract an increase of ionized calcium. These data confirm the existence of an inverse relationship between changes of $\mathrm{pH}$ and changes of ionized calcium concentrations $[4,6]$.

Binding of ionized calcium to proteins is largely dependent on hydrogen ion concentrations [4]. In a study in vivo of Thode et al the slope $\operatorname{logcCa}^{2+} \Delta / \Delta \mathrm{pH}$ was calculated in whole blood and was about $\left.-0.10 \llbracket 4\right]$. Main factors influencing the relation between ionized calcium and $\mathrm{pH}$ are: albumen concentration, changes of bicarbonate and lactate concentrations [7]. Our findings seem to be at variance with findings of Henrich et al, who found during low $B C-D(30.5 \mathrm{meq} / 1)$ no statistically significant increase of ionized calcium [8]. However, their study differs from ours in using another concentration of calcium in the dialysate. We were using $1.75 \mathrm{mmol} / 1$, while Henrich et al were using $1.3 \mathrm{mmol} / 1$ only. This low concentration of calcium will result in either no influx or in loss of calcium from plasma to the dialysate depending on serum phosphate concentration and ultrafiltrate calcium concentration [5].

During low BC-D MAP remained almost the same, while during high and medium BC-D a significant drop in MAP was observed.

During low BC-D an increase of ionized calcium as well as a correction of acidemia will occur. It has been reported that during dialysis an 
increase of serum calcium was leading to an increased blood pressure 13. 9-10]. An increase of blood pressure has been observed as well after infusion of calcium into dogs 1111, normal or hypertensive men [11-12] and patients with a renal disease [3]. This increase of blood pressure is partly due to an increased peripheral resistance, and partly due to an increased cardiac output [13-14]. There are experimental data which support this explanation. Infusion of calcium into the forearm vascular bed of dogs [15] and humans [16] resulted in a vasoconstriction. Ionized calcium is essential for the contraction of the cardiac muscle and vascular smooth muscle cells [12, 17]. Furthermore, the release of catecholamines is calcium dependent [18] and experimental data have suggested that increased ionized calcium activity may augment the release of epinephrine from the adrenal medulla [19], and of norepinephrine from the sympathetic nerve endings [20]. This could be confirmed by Marone et al in a human study, who measured after infusion of $15 \mathrm{mg}$ calcium per $\mathrm{kg}$ body weight in 3 hours a significant increase of epinephrine and norepinephrine [12]. Moreover, the pharmacological effect of catecholamines on vascular smooth muscle proved to be dependent on the concentration of ionized calcium [21].

Whether correction of acidemia during dialysis is related to a better left ventricular performance is a matter of debate. It has been claimed that especially the linear correction of the acidosis during recirculation $B C-D$ will result in a more stable cardiovascular state [1]. However, Henrich et al found that increase of plasma bicarbonate, achieved in one dialysis treatment, did not appear to change ventricular contractility in stable dialysis patients. He concluded that increase of plasma ionized calcium was the most important factor for improving left ventricular contractility and not the correction of acidemia $\lfloor 8 \rrbracket$.

opening of calcium channels, which is necessary for the cellular influx of ionized calcium, is dependent of a physiologic correction of acidosis [22]. Hydrogen ions inhibit cellular entry of calcium [23]. Furthermore hydrogen ions also displace calcium from its important sarcolemnal binding sites [24]. Cellular ionized calcium and its sarcolemnal binding plays a central role in contraction. So a linear slow correction of acidosis together with an increase of ionized plasma calcium will result in a better myocardial contractility and an increase of peripheral vascular tone. 
In conclusion, during dialysis using a dialysate with a caleium concentration of $1.75 \mathrm{mmol} / 1$ a high influx of calcium will occur. During medium and high BC-D no increase of ionized calcium has been observed due to a rapid correction of acidosis to alkalosis. During low BC-D ionized plasma calcium will increase significantly leading to peripheral vasoconstriction and a better myocardial contractility. Both factors counteract the negative effects of fluid removal on blood pressure. Therefore, in critically ill patients and patients with a compromised left ventricular function use of low BC-D $( \pm 30-32 \mathrm{mmol} / 1)$ and high calcium concentration $(1.6-1.75 \mathrm{mmol} / 1)$ seems to be mandatory. 
1. Leunissen KMI, Hoorntje SJ, Fiers HA, Dekkers WT, Mulder AW. Acetate versus bicarbonate haemodialysis in critically ill patients. Mephron 42: (46-151 (1986).

2. Leunissen KML, Cheriex EC, Janssen JHA, Teule GJJ, Mooy JMV, Ramentol $M$, Van Hoof $J P$. Influence of left ventricular function on changes in plasma volume during acetate and bicarbonate dialysis. Nephrology, Dialysis, Transplantation 2: 99-103 (1987).

3. Weidmann P, Massry SG, Coburn JW, Maxwell M. H, Atleson J, Kleeman CR. Blood pressure effects of acute hypercalcemia: studies in patients with chronic renal failure. Ann Intern Med 76: $741-745$ (1972).

4. Thode J, Fogh-Andersen $N$, wimberley PD, Moller Sorensen $A$, Siggaard-Andersen 0 . Relation between $\mathrm{pH}$ and ionized calcium in vitro and in vivo in man. Scand $J$ Clin Lab Invest 43 (165): 79-82 (1983).

5. Goldsmith RS, Furszyfer J, Johnson WJ, Beeler GW JI, Taylor WF. Calcium flux during haemodialysis. Mephron 20: 132-140 (1978).

6. McLean FC, Hastings BA. The state of calcium in the fluids of the body. J Biol Chem 108: 285 (1935).

7. Siggaard-Andersen 0 . The acid-base status of the blood. 4 th ed. Copenhagen: Muksgaard, 83,116, 138 (1976).

8. Henrich WL, Hunt JM, Nixon JV. Increased ionized calcium and left ventricular contractility during haemodialysis. N Engl I Med 310 : $19-23(1984)$.

9. Lifschitz MD. Serum calcium and peripheral resistance. Ann Int Med $77: 482(1972)$.

10. Zawada ET Jr, Bennett EP, Stinson JB, Ramirez G. Serum calcium in blood pressure regulation during haemodialysis. Arch Intern Med 141: $657-658(1981)$.

11. Drop LJ, Scheidegger D. Plasma Lonized calcium concentration: important determinant of the haemodynamic response to calcium infusion. J Thorac Cardiovasc Surg 79: 425-431 (1980).

12. Marone $C$, Eeretta-Piccoli $C$, weidmann $P$. Acute hypercalcemic hypertension in man: role of haemodynamics, catecholamines and renin. Kidney Int 20: $92-96$ (1981). 
13. Vlachakis ND, Frederics $R$, Velasquez $M$, Alexander $N$, Singer $F$, Maronde RF. Sympathetic system function and vascular reactivity in hypercalcemic patients. Hypertension 19: 452-458 (1982).

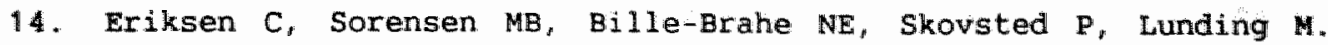
Haemodymamic effects of calcium chloride administrered intravenously to patient with and without cardiac disease during neurolept anaesthesia. Acta Anaesth Scand 27: 13-17 (1983).

15. Overbeck HW, Molnar JI, Haddy EJ. Resistance to blood flow through the vascular bed of the dog forelimb. Am I Cardiol B: 553-41 (1961).

16. Overbeck HW, Pamnani MB, Dexifield RS. Similar vasoconstriction responses to calcium in normotensive and essential hypertensive men. Proc Soc Exp Biol Med 149: 519-525 (1975).

17. Ginsburg R, Esserman LJ, Bristow MR. Myocardial performance and extracellular ionized calcium in a severely failing human heart. Ann Intern Med 98 (1): 603-6 (1983).

18. Rubin RP. The role of calcium in the release of neurotransmitter substances and hormones. Pharmac Rev 22: 389-428 (1970).

19. Greenberg $R$, Kolen CA. Effects of acetylcholine and calcium ions on the spontaneous release of epinephrine from catecholamine granules. Proc Soc Exp Biol Med 121: 1179-84 (1966).

20. Kirkepar SM, Misu Y. Release of noradrenaline by splenic nerve stimulation and its dependence on calcium. J Physiol 188: 219-34 (1967).

21. Khalil $R$, Lodge $N$, Saida $K$, Van Breemen $C$. Mechanism of calcium activation in vascular smooth muscle. J Hypert 5 (4): $55-515$ (1987).

22. Arieff AL, De Fronto RA. Fluid electrolyte and acid base disorders. Volume I, p 295. Churchill Livingstone, New York (1985).

23. Williamson JR, Safer B, Rich $T$, Schaffer $S$, Kobayashi K. Effects of acidosis on myocardial contractility and metabolism. Acta Med Scand 587: 95-112 (1975).

24. Mitchell JH, wildenthal $\mathrm{K}$, Johnson RL Jr. The effects of acid-base disturbances on cardiovascular and pulmonary function. Kidney Int $1: 375(1972)$. 
The aim of this thesis was to investigate pathophysiological processes underlying haemodynamic instability during haemodialysis.

Chapter I provides orientation with respect to the problem. Various factors leading to haemodynamic instability are discussed and a suming up is given of the various questions, which are investigated. The investigations can be divided into two clusters. In the first cluster the influence of optimal dry weight has been investigated (chapter II, III and IV), and in the second the influence of various buffer substrates (chapter $V, V I$ and VII).

\section{Determination of dry weight}

Patients with end stage renal failure have an impaired volume regulation. Excess volume has to be removed during dialysis. Determination of the excess of volume depends on estimation of dry weight. This estimation is mostly done on basis of clinical parameters. Estimation with help of these methods is not well defined. Therefore a more accurate and objective method for estimation of dry weight has been developed. In chapter II a description is given of a non-invasive method, measuring by echography the vena cava inferior diameter (VCD) and collapse index (CI) at deep inspiration. Both indices of vena cava inferior can be determined easily and accurately in more than $95 \%$ of the patients. Inter- and intraobserver variability for the vCD are less than 5\% and $2.5 \%$ respectively, and $10 \%$ and $2.5 \%$ respectively. Both VCD and CI are correlating significantly with invasively measured mean right atrial pressure (MRAP).

Before dialysis no significant correlation was found between VCD/CI and blood volume. The absence of a sigmificant correlation was due to the fact that patients with a large VCD had a wide variation of large blood volumes. However, after dialysis VCD and blood volume correlated significantly, whereas CI did not. Furthermore, the relative decrease of blood volume during ultrafiltration correlated significantly with the relative decrease of VCD. The observations before and after dialysis seem to be contradictory, but can be explained as followi. With increasing blood volume, VCD wll increase until vCD has reached 
his maximal anatomical width. A further increase of blood volume will result in a small increase of diameter only and a steep increase of pressure. So CI might be merely pressure related, while vCD might depend on volume as well as pressure.

Based on findings described before, hypowolaemia (MRAP 43 ming) was defined when there was a VCD of less than $13 \mathrm{~mm}$ and/or a CI of $>75 \%$, while hypervolaemia (MRAP $>B \mathrm{mmHg}$ ) was deflned when there was a VCD of more than $18 \mathrm{~mm}$ and/or a CI of less than $40 \%$.

Reliability of vena cava inferior indices for estimation of the hypovolaemic state was proven by the fact that during haemodialysis with fluid removal in underhydrated patients after dialysis acoording to these indices, mean arterial pressure and stroke volume decreased, while heart rate increased significantly. No such changes were observed in normovolaemic and hypervolaemic patients after dialysis according to these indices.

The reliability of the $\mathrm{CI}$ as a parameter for overhydration was supported by the results of Moreno. He found that a CI $\times 40 \%$ was associated with a MRAP $>7 \mathrm{mmHg}$ (specificity 90\%, sensitivity 91\%). Concerning the reliability of the VCD as a parameter of overhydration: in almost all our patients a VCD $>18$ was associated with a high MRAP. Moreno found in 65 patients with a known MRAP, that a VCD $>18$ mmas a parameter of an elevated MRAP had a specificity of $83 \%$ and a sensitivity of $88 \%$.

The determination of serum alpha-atrial natriuretic peptide (alpha-hANP) has been advocated as indicator for fluid status as well. Therefore the relationship between alpha-h-ANP and VCD, CI, left atrial diameter, left ventricular end diastolic diameter, ultrafiltration volume, was studied.

In chapter III a significant correlation was found between VCD and alpha-h-ANP ( $r=0.73$, p 0.001$)$, whereas there was no correlation between the other parameters and alpha-h-ANP. It has been advocated to express VCD per square meter body weight, because VCD will depend on habitus of a patient. Therefore the correlation between alpha-h-ANP and $\mathrm{VCD} / \mathrm{m}^{2}$ was computed. The VCD, corrected for body surface area, showed a better correlation with alpha-h-ANP before dialysis $(I=0.78$, p 00.0001$)$ compared to the incorrected value. Therefore in other studies the corrected VCD was used. VCD before dialysis had a predictive value 
concerning the decrease of alpha-h-ANP due to dialysis with fluid removal. Fluid removal induced in hypervolaemic patients a significant decrease of alpha-h-ANP levels, whereas during removal of the same amount of fluid in normo- and hypovolaemic patients alpha-h-ANp did not change. After achieving normovolaemia alpha-h-ANp levels in patients with mitral valve insufficiency grade $I$ were doubled compared to mormovolaemic patients without mitral valve insufficiency. The latter findings suggest, that alpha- $h$-ANP can be released by left atrium as we 11 .

The limitations of alpha-h-ANP for estimation of dry weight are clear. A high alpha-h-ANP level means either fluid overload or high left atrial pressure due to a mitral valve insufficiency, and a normal alpha-h-ANP level could either mean normovolaemia or hypovolaemia. So changes in alpha-h-ANP levels during dialysis rather than the absolute level of alpha-h-ANP are giving an indication of dry weight.

More prove for the reliability of vena cava inferior indices for the determination of fluid status was delivered in chapter IV. In this chapter changes of macro- as well as microcirculation were studied during dialysis of patients, who were either normo- or hypervolaemic, or hypovolaemic according to vena cava inferior indices.

Patients who were hypovolaemic after dialysis showed a significant decrease of stroke volume, mean arterial pressure and an increase of heart rate, whereas patients, who were normovolaemic or still hypervolaemic after dialysis, showed no changes.

Skin perfusion was measured by Laser Doppler and intravital microscopy of nailfold capillaries. In patients, who were hypovolaemic after dialysis, skin perfusion decreased. This was probably due to decreased stroke volume and an increase of serum adrenaline concentration. Adrenaline has an inhibitory effect on cutaneous blood flow. patients, who were normovolaemic or still hypervolaemic after dialysis, showed a significant increase of skin perfusion. This increased skin perfusion might be related to local autoregulatory mechanisms as the myogenic response. When data of all patients were compiled, VCD but not CI correlated significantly with changes of Laser Doppler signals and changes of red blood cell velocity.

In conclusion, vena cava inferior indices, especially vena cava inferior diameter, are excellent markers for fluid status of dialysis 
patients and will provide a reliable tool for estimation of ary weight in haemodialysis patients. Because of aforementioned limitations of alpha-h-AMP levels with regard to fluid status, also in clinical practice preference should be given to echography of vena cava inferior and determination of VCD and its collapse index.

\section{Buffer substrate}

One of the aims of haemodialysis is correction of metabolic acidosis. For that purpose, buffers are added to dialysates, either acetate or bicarbonate.

The effects of acetate and bicarbonate on haemodynamic stability were studied in acute and chronic haemodialysis patients.

In critically ill patients with acute renal failure a significant decrease of left ventricular function was observed during acetate dialysis compared to bicarbonate dialysis (chapter $V$ ), resulting in a decrease of blood pressure. This decrease of left ventricular function might be caused by various factors related to the use of acetate, such as hypoxaemia, hypocapnia and an incomplete correction of acidosis.

During acetate dialysis of chronic haemodialysis patients (chapter VI) a decreased plasma volume preservation was found compared to bicarbonate dialysis. Moreover, during acetate dialysis a difference in plasma volume preservation between patients with normal and patients with compromised left ventricular function was found. In patients with a normal left ventricular function plasma volume was decreased in the first hour of acetate dialysis only, whereas in patients with impaired left ventricular function the decrease of plasma volume was even more pronounced during acetate dialysis. Ultrafiltration during acetate dialysis in patients with an impaired left ventricular function has to be stopped because of a severe hypotension, leading to a decrease of net amount of ultrafiltration volume of $60 \%$ compared to bicarbonate dialysis. The difference in plasma volume preservation was not related to changes of osmolality and colloid oncotic pressure.

The negative effect of acetate might be related to a difference in plasma volume preservation. During fluid removal plasma volume will be restored by transport of fluid from the extravascular compartment to the intravascular compartment. The refilling rate is related to the capillary starling equilibrium. Acetate might interfere with this 
equilibrium because of vasodilation, cardiodepression and release of 1ymphokines, wich could interfere with capillary permeability.

During dialyses correction of the acidosis will occur through the influx of buffer substrate such as bicarbonate. Rate of influx of the buffer substrate will determine the speed and height of the correction of $\mathrm{pH}$. It was suggested that not correction of acidosis, but an increase of serum ionized calcium is the most important factor for stabilization of haemodynamic state. An increasing ionized calcium concentration improves left ventricular function and increases vascular tone. The increase of ionized calcium is inversely correlated with the increase of $\mathrm{pH}$. Moreover, a physiological pH is necessary for calcium influx into the cells, inducing an improved myocardial contractility and an increased vascular tone. This pivotal role of ionized calcium and $\mathrm{pH}$ for the regulation of blood pressure was shown in chapter VII. Notwithstanding the same considerable influx of calcium during high, medium and low bicarbonate dialysis, a significant increase of ionized calcium was observed during low bicarbonate dialysis dialysis only. During medium and high bicarbonate no significant increase of ionized calcium occurred due to a rapid change of acidosis to alkalosis.

During low bicarbonate dialysis mean arterial pressure and pulse rate remained almost the same, while during high and medium bicarbonate haemodialysis a significant decrease of mean arterial pressure and a significant increase of heart rate was observed. Ultrafiltration volumes were comparable. A increasing ionized calcium was counteracting the negative effect of fluid removal on blood pressure.

It can be concluded that for an optimal cardiovascular stability during haemodialysis an optimal fluid status is very important. Also on the long term an optimal dry weight is mandatory, because chronic fluid overload and chronic dehydration will lead to congestive heart failure or left ventricular concentric hypertrophy. The use of echography of inferior vena cava, measuring the anterior-posterior diameter and collapsibility index, proved to be a rellable tool for estimation of fluid status. Haemodynamic stability during haemodialysis is also dependent on the used buffer substrate, especially in critically $i l 1$ patients and in patients with a compromised left ventricular function. Because of the pivotal role of ionized calcium for left ventricular 
contractility and peripheral vascular tone. and the inverse relationship between $\mathrm{pH}$ and ionized calcium, preference should be given to dialysates, containing a low concentration of bicarbonate.

In clinical practice there are other well defined circumstances, in which bicarbonate dialysis is indicated. Because of the effects of acetate, such as hypoxaemia, hypocapnia and incomplete correction of the acidosis, bicarbonate dialysis should be advocated in elderly patients, patients with chronic obstructive lung diseases and patients with coronary sclerosis. There are also reports of patients with a decreased metabolic capacity of acetate, resulting in hyperacetataemia and an increasing metabolic acidosis because of organic acid formation, especially when high flux membranes are used.

Although bicarbonate as a physiological buffer is to be preferred, the extra cost and complexity cannot justify its use in all patients at this moment. The extra cost per year of one bicarbonate dialysis module (performing 250 dialyses) is about $\$ 4000$. In this amount is included the initial price of the module, the service costs and the extra costs of the bicarbonate concentrate.

So for clinical practice a decision tree has been made for dealing with the question acetate or bicarbonate dialysis (figure 1 ). 


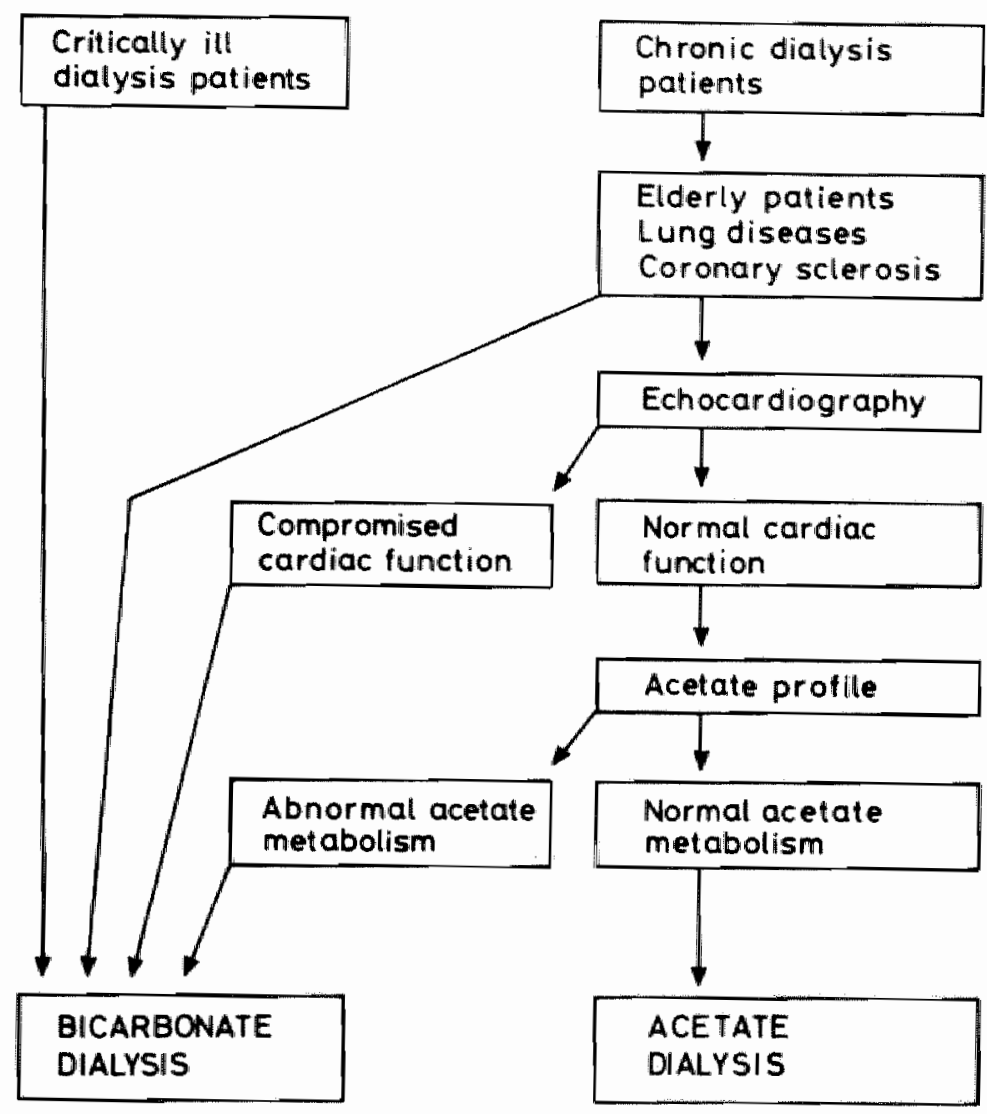

\section{Fiqure 1:}

Decision tree concerning acetate or bicarbonate for haemodialysis in clinical practice 
102

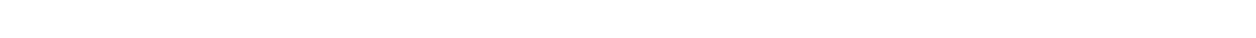




\section{SNMAMVATTINE}

De diverse onderzoekingen, die beschreven, zijn in dit proefschrift, zijn verricht met het doel om na te gaan welke pathofysiologische mechanismen ten grondslag liggen aan dalingen van de bloeddruk tijdens haemodialyse. In hoofdstuk I wordt een oriëntatie in de problematiek gegeven. Diverse factoren die aanleiding geven tot bloeddrukdalingen worden besproken. Op het einde van het hoofdstuk wordt een opsomming gegeven van de vraagstellingen van de diverse onderzoekingen. Deze onderzoekingen kunnen ingedeeld worden in twee clusters. In het eerste cluster wordt de invlaed van het streefgewicht bestudeerd (hoofdstuk II, III en IV), terwijl in het tweede de invloed van het gebruikte buffersubstraat is onderzocht (hoofdstuk $V$, VI en VII).

\section{Bepaling van het streefqewicht}

Patiënten met een terminale nierinsufficiëntie zijn niet meer in staat hun water- en zouthuishouding te reguleren. Het teveel aan vocht zal tijdens een dialysebehandeling door middel van ultrafiltratie verwijderd moeten worden. Bepaling van de hoeveelheid vocht die onttrokken moet worden (het ultrafiltraat) hangt af van het zogenaamde streefgewicht. Dit streefgewicht wordt meestal vastgesteld aan de hand van kilmische symptomen van over- en ondervulling. Bepaling van het streefgewicht met behulp van deze middelen is subjectief en niet gestandaardiseerd. Daarom is een meer gestandaardiseerde en objectieve methode van bepaling van het streefgewicht ontwikkeld.

In hoofdstuk II wordt een niet-invasieve methode beschreven voor het bepalen van het streefgewicht. Met behulp van echografie wordt de diameter van de vena cava inferior (VCD) en de mate van collaberen tijdens diepe inspiratie (collaps index = CI) op gestandaardiseerde wijze gemeten. De diameter en de collaps index zijn gemakkelijk te bepalen in meer dan $95 \%$ van de patiënten. De inter-en intraobserver variabiliteit is voor de meting van vCD respectievelijk <5\% en $<2.5 \%$ en voor de meting van CI <10\% en $62.5 \%$. De VCD en CI bleken significant te correleren met invasief gemeten rechter atrium drukken.

voor haemodialyse bleek geen significante correlatie te bestaan tussen de VCD, CI en het bloedvolume. De afwezigheid van een correlatie was mogelijk een gevolg van het feit, dat patiënten met een wijde vcD een 
grote spreiding vertoonden van het bloedvolume. Na dialyse bleek $\mathrm{CI}$ niet, maar VCD wel, significant gecorreleerd te zijn met het bloedvolume. Bovendien bleek de relatieve afname van het bloedvolume ter gevolge van ultrafiltratie significant te correleren met de afname van de VCD. Deze bevindingen voor en na dialyse lijken met elkaar in tegenspraak, maar kunnen als volgt worden verklaard. Bij het stijgen van het bloedvolume zal de diameter toenemen totdat deze zijn maximale anatomische wijdte heeft bereikt. Een verdere toename wan bloedvolume zal dan slechts resulteren in een geringe toename van de diameter, terwijl de aruk sterk zal toenemen. De CI lijkt derhalve meer een afspiegeling te zijn van de druk, terwijl de diameter afhankelijk is van zowel het volume als de druk.

Gebaseerd op voornoende bevindingen werd de aanwezigheid van ondervulling waarschijnlijk geacht indien de $V C D<13 \mathrm{~mm}$ en/of de CI $>75 \%$ bedroeg, en overvulling indien de $\mathrm{VCD}>18 \mathrm{~mm}$ en/of de CI (40\% bedroeg. De waarde van deze indices voor het bepalen van de volumestatus werd aangetoond in twee groepen patiënten, waarbij de volumestatus na dialyse was bepaald aan de hand van deze inidces. De eerste groep bestond uit patiënten die ondervuld waren, de tweede groep uit patiënten die overvuld waren. Gedurende dialyse met ultrafiltratie van patiënten uit de eerste groep werden veranderingen in de circulatie geobserveerd, die pasten bij ondervulling, zoals afname van de bloedaruk en het slagvolume, met een toename van de polsfrequentie. Deze veranderingen werden niet wargenomen bij patiënten, die normovolaemisch of overvuld waren.

De bepaling van het serum alpha-atriale natriuretisch peptide (alphah-ANP) zou ook een indicatie kunnen geven over de volumestatus van de patient. Daarom is in hoofdstuk III nagegaan wat de relatie was tussen alpha-h-ANP, VCD, CI, diameter van het linker atrium, linker ventrikel eind diastolische diameter en hoeveelheid ultrafiltraat. Er bleek een significante correlatie te bestaan tussen vCD en alpha-h-ANP $\quad(r=0.73$; p 0.001$)$, terwijl er geen correlatie bestond tussen de andere variabelen en het alpha-h-ANP. Er zijn aanwijzingen dat het nauwkeuriger is VCD uit te drukken per $\mathrm{m}^{2}$ lichaamsoppervlak, omdat de VCD afhankelijk kan zijn van de habitus van de patient. Om die reden is de correlatie tussen alpha-h-ANP en VCD per $\mathrm{m}^{2}$ opnieuw berekend. Het bleek dat de VCD gecorrigeerd voor lichaamsoppervlak een betere 
correlatie toonde met het alpha-h-ANp voor dialyse $(r=0.78 ; p<0.0001)$ dan met de niet gecorrigeerde waarde. Daarom is in de verdere onderzoekingen slechts gebruik gemaakt van de vCD, gecorrigeerd voor 1ichaamsopperviakte.

De VCD voor dialyse bleek een predictieve waarde te hebben ten anzien van de afname van het alpha-h-ANP gedurende dialyse en ultrafiltratie. Dezelfde hoeveelheid ultrafiltraat induceerde in patiënten, die voor dialyse overvuld waren volgens VCD en CI, een significante afname van het alpha-h-ANP, terwijl in patiënten die voor dialyse normo- en hypovolaemisch waren volgens $V C D$ en $C I$ alpha-h-ANP niet veranderde. Na het bereiken van normovolaemie was het serum ANP bij patiënten. met mitraalinsufficiẻntie graad I zonder pulmonale hypertensie tweemaal zo hoog in vergelijking met normovolaemische patiënten zonder mitraalinsufficiëntie. Deze laatste waarneming suggereert dat de productie van alpha-h-ANP wordt gestimuleerd door een verhoogde linker atriumdruk.

De beperkingen van het alpha-h-ANP als indicatie voor de volumestatus zijn duidelijk geworden uit deze onderzoekingen. Een hoge alpha-h-ANPspiegel betekent of overvulling of een hoge linker atriumdruk ten gevolge van een mitraalklepinsufficiëntie, terwijl een normale alpha-hANP-spiegel gevonden kan worden bij zowel normovolaemie als bij ondervulling. Een enkele bepaling van het alpha-h-ANP geeft weinig zinvolle informatie over de vullingsgraad. Eerst meer informatie daarover kan men verkrijgen door veranderingen van het alpha-h-ANP te meten tijdens ultrafiltratie.

Nog meer bewijs van de bruikbaarheid van de vena cava indices als mat voor de vullingsgraad werd geleverd door de resultaten van de onderzoekingen, beschreven in hoofdstuk IV. In dit hoofdstuk werden veranderingen van macro- en microcirculatie bestudeerd gedurende haemodialyse met ultrafiltratie. De patiẻnten werden verdeeld op grond van de vena cava indices na dialyse in twee groepen. Een groep patiënten, die of overvuld of normovolaemisch was, en een groep patiënten, die ondervuld was. Patiënten, die na dialyse ondervuld waren, toonden een significante afname van het slagvolume, de gemiddelde arteriële bloeddruk en een significante toename van de hartfrequentie. Deze veranderingen werden niet gevonden bij de andere groep.

De huiddoorbloeding werd gemeten door middel van de Laser Doppler en 
intravitaalmicrozcopie van de capillairen in de nagelplooi. In patiênten, die na dialyse ondervuld waren, nam de huiddoorbloeding significant af. Deze afname kan toegeschreven worden aan een gelijktijdig wargenomen afname van het slagvolume en een toename van de concentratie wan het serum adrenaline. zoals bekend geeft een toename van adrenalineconcentratie een vermindering van de huiddoorbloeding. patiënten, die na dialyse normovolaemisch of nog steeds overvuld waren, toonden daarentegen significante toename van de huiddoorbloeding. Deze toegenomen huiddoorbloeding zou mogelijk kunnen berusten op locale autoregulatie, zoals de myogene respons. Manneer de resultaten van alle patiënten samen genomen werden, bleek de VCD significant voorspellende waarden te hebben ten aanzien van de veranderingen van de Laser Doppler en veranderingen in de snelheid van de rode bloedcellen in de capillairen in de nagelplooi. Een dergelijke relatie kon niet worden aangetoond voor de $\mathrm{CI}$.

Concluderend kan men stellen dat de indices van de vena cava inferior en met name de vena cava inferior diameter een goede indicatie geven over de volumestatus van dialysepatiénten.

Deze indices vormen betrouwbare hulpmiddelen bij de bepaling van het streefgewicht van haemodialysepatiënten. Het bepalen van alpha-h-ANP lijkt voor de praktijk weinig zinvol bij het bepalen van het sitreefgewicht.

\section{Type buffer}

Tijdens haemodialyse wordt de metabole acidose, die een gevolg is van de nierinsufficientie, gecorrigeerd. Om dit doel te bereiken wordt aan het dialysaxt een buffer (acetaat of bicarbonat) toegevoegd. De effecten van acetal en bicarbonat op de haemodynamische stabiliteit zijn bestudeerd bij patiënten met acute en chronische haemodialyse. Bif acute patiënten bleek ex een significante afname te zijn van de linker ventrikelfunctie gedurende acetaatdialyse in vergelijking met bicarbonaatdialyse (hoofdstuk $v$ ). Deze afname van linker ventrikelfunctie had als gevolg dat er een significante daling van de bloeddruk optrad tijdens acetaatdialyse. Deze afname van de linker ventrikelfunctie kan worden toegeschreven aan diverse factoren, die gerelateerd zijn aan het gebruik van acetaat, zoals hypoxie, hypocapnie en een incomplete correctie van de acidose. 
Gedurende de acetaatdialyse werd ook een verminderde plasmawolumepreservatie gevonden in vergelijking net bicarbonatualirse. Deze latste warneningen werden verrich bij chronische hamodilysepatienten (hoofdstut VI). Met name werd dit verschil wargenonen, as men tijdens acetaatdilyse de gegevens over plasmavolumepreservatie vergeleek van patienten met een normale net patienten met een verminderde linker ventrikelfunctie. In patienten net een normale Iinker ventrikelfunctie bleek het plasmavolume met name in het eerste wor van de dialyse afgenomen te zijn. Deze afname van het plasmavolume was ernstiger bij patienten met een verminderde linker ventrikelfunctie en durde daarenboven tijdens de gehele dialyse. Dientengevolge moest de utrafiltratie gestopt worden in verband met ernstige bloeddrukdalingen. Dit had als gevolg dat er 60t minder geultrafiltreerd kon worden tijdens acetaatdiayse in pergelijking net bicarbonaatdialyse. Deze veranderingen van de plasmavolumepreservatie waren niet gerelateerd an veranderingen in de osmolariteit en de collold-osmotische druk.

Het negatieve effect wan acetat kan mogelijk een gevolg zijn van verschil in plasmavolumepreservatie. Tijdens ultrafiltratie wordt het plasmawolume aangevuld door transport van vocht van het extravasculair compartiment naar het intravasculair compartiment. De hoeveelheid getransporteerd vocht is afhankelijk van het stariing equilibrium van het capillair. Het is mogelijk dat acetaat interfereert met dit evenwicht vanwege het feit dat het aanleiding geeft tot vasodilatatie, de hartfunctie onderdrukt en de productie van lymfokinines stimuleert. Deze lymfokinines kunnen interfereren met de permeabiliteit van het capillair..

Tijdens dialyse wordt de acidose gecorrigeerd door de instroom van buffers zoals bicarbonaat. De mate van instroom van deze buffer zal de snelheid van de correctie en de hoogte van de $\mathrm{pH}$ bepalen. Er zijn aanwijzingen dat de belangrijkste factor voor een stabiele haemodynamiek niet de correctie van de acidose is, mar de toename van het geioniseerd calcium. De toename van geioniseerd calcium verbetert de linker ventrikelfunctie en geeft aanleiding tot een toename van de vasculaire tonus. De toename van het geioniseerd calcium is echter ongekeerd gecorreleerd met de toename van de $\mathrm{pH}$. Het is overigens zo dat een fysiologische $\mathrm{pH}$ nodig is voor de influx van calcium in de 
cellen. Deze influx bewerkstelligt dan een toename van de contractiliteit van de hartspier en een toename van de vaattonus.

In hoofdstuk. VII wordt aangetoond dat het geinoniseerd calcium inderdaad een zeer belangrijke rol speelt bij de regulatie van de bloeddruk tijdens dialyse. Ondanks het feit dat dezelfde aanzienlijke hoeveelheid calciun instroomt tijdens dialyses met drie verschillende concentraties bicarbonat (of hoog, of medium of laag), is slechts een significante toename van het geioniseerde calcium wargenomen tijdens laag bicarbonaat. Tijdens de dialyses met dialysaat, dat of hoog of medium bicarbonatconcentraties bevatte, is geen significante toename gevonden van het geioniseerde calcium. Dit wordt veroorzaakt door de zeer snelle verandering van acidose naar alkalose. Tijdens dialyse met een lage bicarbonatconcentratie zijn nauwelijks veranderingen waargenomen van de bloeddruk en de pols, terwijl tijdens dialyse met hogere bicarbonat concentraties de bloeddruk significant daalde en de pols significant steeg. De hoeveelheid ultrafiltrat was gedurende alle drie de procedures vergelijkbaar. Het lijkt er dus op dat een toename van het geïoniseerd calcium het negatieve effect van ultrafiltratie op de bloeddruk tegengat. Tijdens dialyse speelt het geioniseerd calcium derhalve een cruciale rol bij het handhaven van de bloeddruk.

Concluderend kan men dus stellen dat, wat betreft optimale haemodynamische stabiliteit tijdens dialyse, een optimale volumestatus zeer belangrijk is. Ook voor de lange termijn is een optimale vullingsgraad uitermate belangrijk, omdat zowel chronische overvulling als chronische onderwulling tot afwijkingen van het hart kunnen leiden.

Toepassing van de echografie van de vena cava inferior, warbij de voorachterwartse diameter en de mate van collaberen worden gemeten, lijkt een veelbelovende methode voor het bepalen van de vullingsgraad. De haemodynamische stabiliteit tijdens dialyse is ook afhankelijk van het type buffer in het dialysaat. Het type buffer is met name van belang bij patiënten, die acuut ziek zijn, of bij patiënten met een slechte linker ventrikelfunctie. Omdat geioniseerd calcium zeer belangrijk is voor de functie van het linker ventrikel en de vaattonus, en er verder een omgekeerde relatie bestaat tussen $\mathrm{pH}$ en de ionisatiegraad van het calcium, zal men bij deze patiënten sterk de voorkeur moeten geven aan dialyse, waarbij gebruik gemaakt wordt van lage concentraties bicarbonat in het dialysaat. 
Er zijn overigens ook andere situaties, warbij het gebruik van bicarbonat in het dialysaat is geindiceerd. Het is aanbevelenswaardig om bij oudere patiënten, patiënten met longlijden en patiënten met coronair sclerose, bicarbonat te gebruiken, ondat het gebruik van acetaat aanleiding geeft tot hypoxaemie, hypocapnie en en incomplete correctie van de acidose. Ook zijn er patiënten, die een afgenomen capaciteit hebben om acetaat te metaboliseren, waardoor er hoge acetaatspiegels ontstaan, die aanleiding geven tot toename van de metabole acidose als gevolg van vorming van organische zuren. Deze lage capaciteit om acetaat te metaboliseren zal vooral aanleiding tot problemen geven als de zogenaamde "high flux" membranen worden gebruikt.

ofschoon theoretisch de voorkeur gegeven moet worden aan de fysiologische buffer bicarbonat, is dat niet noodzakelijk bij elke patient. EI zijn trouwens extra kosten verbonden aan de toepassing van bicarbonaat. De extra kosten op jaarbasis voor een bicarbonaatmodule, warmee men ongeveer 250 dialyses kan uitvoeren, is ongeveer 10.000 . In dit bedrag zijn inbegrepen de prijs van de module, de servicekasten en de extra kosten verbonden aan het gebruik van bicarbonaat. Bij de keuze tussen acetaat-en bicarbonaatdialyse kan men gebruik maken van een beslisboom ( $z$ ie figure 1 van de engelse samenvatting). 
Het aantal patiënten, dat poor nierfunctievervangende therapie in aanmerking komt, neent nog steeds sterk toe in Nederland. Een relatief hoog percentage van deze patiënten komt niet in aanmerking voor en niertransplantatie. Deze patiënten zullen derhalve voor hun verdere leven afhankelijk blijven van haemodialyse danwel CAPD. Tevens bestaat er een structureel tekort aan donornieren. Dit zal ertoe leiden dat niet alleen het aantal patiënten dat langdurig wordt behandeld met dialyse sterk zal toenemen, maar ook dat patiënten gemiddeld langer afhamkelijk blijven van dialyse of CAPD.

Er zijn diverse complicaties bekend van chronische dialysebehandeling, zoals cardiovasculaire aandoeningen, polyneuropathie, botafwijkingen en beta-2-microglobuline neerslagen onder andere in de gewrichtskapsels. Deze aandoeningen bepalen niet alleen de prognose van de patiënten, maar met name ook de kwaliteit van leven. Het bewustzijn van een machine afhankelijk te zijn is al een opgave voor dialysepatiënten, maar de angst voor acute problemen tijdens dialyse of complicaties op langere termijn maken het ondergaan van deze therapie tot een relatief zware psychische en lichamelijke belasting. Mede on deze redenen is het geboden dat de dialysebehandeling verder geperfectioneerd moet worden. Om dit te kunnen bereiken is onder andere een goed inzicht nodig in de pathofysiologische veranderingen, die tijdens de dialyse geinduceerd worden. Het feit dat er drie keer per week, in veel gevallen slechts twee keer per week, gedurende drie tot vier uren "schoon schip" gemaakt wordt, moet sterke verschuivingen geven in verschillende fysiologische regelmechanismen. Voor een betere behandeling van de dialysepatiënt maar ook om wetenschappelijke redenen is het zaak dat in Nederland, eens de bakermat van de klinische dialysebehandeling, de research op haemodialysegebied opnieuw sterk wordt gestimuleerd.

Met het onderzoek voor dit proefschrift werd gestart in het Catharina Ziekenhuis te Eindhoven, afdeling Interne Geneeskunde. Met name op de dialyseafdeling bestond er voor een perifeer ziekenhuis een unieke onderzoekstraditie. De eerste schrede op het glibberige pad van klinisch onderzoek werd verricht onder leiding van Dr. Flendrig en Dr. Mulder, later Dr. Mulder en Dr. Hoorntje.

Na mijn vertrek naar ziekenhuis sint Annadal, later Academisch ziekenhuis Maastricht, heb ik tijdens en na mijn nefrologische 
opleiding dit onderzoek kumnen voortzetten onder stimulerende begeleiding van Dr. Van Hooff en Prof. Flendrig.

De nodige diepgang is mede tot stand gekomen dankzij het feit dat harten vatziekten een van de belangrijkste onderzoeksthema's is van de Medische Faculteit. Hierdoor was het mogelijk dat met zeer veel personen van gedachten gewisseld kon worden over de haemodynamische problemen tijdens dialyse.

Ik wil in het bijzonder de volgende personen vermelden.

Emile Cheriex van de afdeling Cardiologie, wiens deskundig inzicht in de noninvasieve haemodynamische diagnostiek van cruclaal belang is geweest voar het tot stand komen van dit proefschrift. Dick Slaaf van de afdeling Biofysica introduceerde $\mathrm{mij}$ in de wereld van de microcirculatie en hielp mij op weg in deze intrigerende materie, mede door een niet aflatende stroom van kritische vragen.

De uitstekende medewerking van Cees Degenar en Paul Menheere van de afdeling klinische chemie maakte het mogelijk dat gegevens, noodzakelijk voor de diverse onderzoekingen, snel ter beschikking kwamen. De discussies met Jaap Teule van de afdeling Nucleaire Geneeskunde hebben mijn inzicht in de haemodynamiek vergroot.

Bert van den Berg wil ik danken woor de hulp bij het onderzoek, de eindeloze discussies maar ook voor het vele plezier dat we gehad hebben op momenten dat relativeren geboden was.

De leden van de beoordelingscommissie, Prof.Dr. Allessie, Prof.Dr. Shaldon, Dr. Mulder, Prof.Dr. Struyker Boudier en Dr. Slaaf wil ik bedanken voor hun constructieve kritiek.

Mijn collega's van de afdeling Nefrologie, Liang Kho en Jaap Mooy, waren steeds bereid mijn andere taken over te nemen op momenten dat ik met onderzoek bezig was.

veel hulp kreeg ik ook van de verpleging van de dialyse-afdeling en van Piet Claessen, techricus op de afdeling Haemodialyse.

Desirée van Schoubroeck heeft zorg gedragen voor het persklaar maken van dit proefschrift, warvoor ik haar meer dan dank ben verschuldigd.

Tiny, je hebt het grootste deel van de organisatie van het huishoudelijk bedrijf op je moeten nemen en mij toch nog gesteund in mijn werk. 
Martijn, onze zoon, zat vele uren met mij achter het bureau, hetgeen het papierverbruik voor dit proefschrift mogelijk verdubbeld heeft. zijn aanwezigheid gaf mij echter tegelijk de moed on verder te gaan. Jeroen, nog slechts enkele maanden oud, wal in de toekomst recht hebben op meer aandacht van mijn zijde.

Voor de dialysepatiënten hoop ik dat ik met dit proefschrift een bijdrage geleverd heb aan de verbetering van een ingrijpende behandeling warvan zij afhankelijk zijn. Dit proefschrift moge ook een tegenprestatie zijn voor al het ongemak, dat onze dialysepatiënten hebben willen dragen door aan dit onderzoek belangeloos hun medewerking te verlenen.

Eysden, 9 december 1988 


\section{CURRTCULUN VTTAE}

The author of this thesis was born on February 9,1954 in Heerlen, The Netherlands. He graduated from grammar school st. Jans Lyceum, HBS-B in Moensbroek in 1972. In the same year he attended the Medical Faculty at the Rifksuniversiteit utrecht. After he received his medical degree in 1979, he started his residency at the Internal Medicine department of the Catharina Hospital in Eindhoven (head until 1982: Dr. J.A. Flendrig, thereafter Dr. H.F.P. Hillen). In april 1984 he was registered in Internal Medicine and immediately thereafter he started his training to nephrologist at the division of Nephrology (head: $\mathrm{Dr}$. J.P. van Hooff) of the department of Internal Medicine (head: Prof.Dr. J.A. Flendrig), Academic Hospital Maastricht, the Netherlands. This training was supported by a grant of the Dutch Kidney Foundation. Since 1986, he is a member of the department of Internal Medicine, working in the division of Nephrology. 


\section{PUBLICatrons}

\section{PAPERS}

1. J.P. van Hooff, K.M.L. Leunissen, W. V.d. Staak.

Cyclosporin and psoriasis.

Lancet i: 335,1985 .

2. K.M.L. Leunissen, P.W. Waterval, J.P. van Hooff. Anaphylactic reaction to intravenous cyclosporin. Lancet i: 636,1985 .

3. K.M.L. Leunissen, F.T. Bosman, J.P. van Hooff. Cyclosporin, uric acid, and the kidney.

Lancet i: 702,1985 .

4. G. Kootstra, P.J.G. Jorning, J.A. van der Vliet, T.J.M. Ruers, K.M.L. Leunissen, J.P. van Hooff, P.M. van den Berg-Loonen. The usability of pediatric donor kidneys for transplantation. Proceedings Second International Middle East Symposium on organ Transplantation, 1985.

5. J.P. van Hooff, A. van Leeuwen, L. Paul, K.M.L. Leunissen, C. Lecomte, J. D'Amaro, B. Cohen, G.R.J. Alexandre, J.J. van Rood.

The influence of matching for "Broad reacting antigens" on long term kidney graft survival.

Transpl Proc XVII (6): 2205-2206, 1985.

6. K.M.L. Leunissen, S.J. Hoorntje, W.T. Dekkers, H.A. Fiers, A.W. Mulder.

Acetate versus bicarbonate hemodialysis in critically ill patients.

Nephron 42 (2): 146-151, 1986 .

7. K.M.L. Leunissen, F-J.F.E. Vismans, R.J.M. van Leendert, J.P. van Hooff.

Successful treatment of persistent posttransplant hyperparathyroidism with oral diphosphonate.

Transplantation 41 (5): 666, 1986.

8. G. Kootstra, P.J.G. Jorning, J.P.A.M. Vroemen, J.A. van der Vliet, T.J.M. Ruers, K.M.L. Leunissen, J.P. van Hooff, P.M. van den Berg-Loonen. 
De bruikbaarheid van nieren van kinderen c.q. pasgeborenen voor transplantatie.

Liber Amicorum voor Prof.Dr. P.J. Kuijjer. Uitgeverif Van Gorcum, mei 1986.

9. J.P.A.M. Vroemen, T.J.M. Ruers, P.J.G. Jorning, J.A. van der Vliet, K.M.L. Leunissen, J.P. van Hooff, G. Rootstra.

Surgical experiences with neonatal grafts.

Transpl Proc XVIII (3): 482-484, 1986.

10. T.L. Kho, R. Kengen, K.M.L. Leunissen, J. Teule, J.P. van Hooff. Hydergine and reversibility of cyclosporin nephrataxicity.

Lancet il: $394,1986$.

11. K.M.L. Leunissen, T.J.M. Ruers, F. Bosman, G. Kootstra, J.P. van Hooff.

Intravascular coagulation and kidney donation.

Transplantation 42 (3): 307-308, 1986.

12. K.M.L. Leunissen, F-J.F.E. Vismans, W. Grave, R.J.M. van Leendert, J.P. van Hooff.

The effect of APD (3-amino-1-hydroxypropylidene-1, 1-bisphosphonate) in persistent posttransplant hyperparathyroidism.

Transpl proc XVIII (5): 1441-1442, 1986.

13. K.M.L. Leunissen, G.H. Beuman, F.T. Bosman, J.P. van Hooff. Cyclosporin metabolites and nephrotoxicity.

Lancet ii: 1398, 1986.

14. P.M. van den Berg-Loonen, K.M.L. Leunissen, J.P. van Hooff, G. Kootstra.

B-cell antibodies after planned transfusion.

Transpl Proc XIX (1): 743, 1987.

15. L.A.M. Frenken, K.M.L. Leunissen, P.M. van den Berg-Loonen, G. Kootstra, J.P. van Hooff.

Blood eosinophilia and renal allograft rejection.

Transpl Proc XIX (1): 1584-1585, 1987.

16. T.L. Kho, G.J.J. Teule, K.M.L. Leunissen, G.A.K. Heidendahl, P.J. Lijnen, A.K. Amery, J.P. van Hooff.

Nephrotoxic effect of cyclosporine A can be reversed by dopamine. Transpl Proc XIX (1): 1749-1753, 1987. 
17. K.M.L. Leunissen, C.P. Degenaar, G.J.J. Teule, T.L. Kho, L.A.M. Frenken, J.P. van Hooff.

Impairment of liver synthetic function and decreased liver flow during cyclosporine $\mathrm{A}$ therapy.

Transpl Proc XIX (1): 1822-1824, 1987 .

18. G. Kootstra, J.P. van Hooff, P.J.G. Jörning, K.M.L. Leunissen, C.J. van der Linden, E.K.M. Beukers, W.A. Buurman..

A new variant for whole pancreas grafting, early experience.

Transpl Proc XIX (1): 2314-2318, 1987.

19. G. Kootstra, J.P. van Hooff, P.J.G. Jörning, K.M.L. Leunissen, C.J. van der Linden, E.K.M. Beukers, W.A. Buurman.

Pancreatic transplantation in patients with type I diabetes: the experience in Mastricht with a new model.

N J Surgery $39(1): 32-36,1987$.

20. G. Kootstra, W.A. Buurman, J.G. Maessen, J.P. van Hooff, K.M.L. Leunissen, T.J.M. Ruers, M.A.M. Vromen.

The risk factor of warm ischemia in renal transplantation.

Proceedings XVIII International Course on Transplantation and Clinical Immunology, mei 1986, p 322.

21. K.M.L. Leunissen, E.C. Cheriex, J.H.A. Janssen, G.J.J. Teule, J.M.V. Mooy, M. Ramentol, J.P. van Hooff.

Influence of left ventricular function on changes in plasma volume during acetate and bicarbonate dialysis.

Nephrol Dial Transpl 2: 99-103, 1987.

22. A.A.M. Blaauw, K.M.L. Leunissen, E.C. Cheriex, J. Wolters, G. Kootstra, J.P. van Hooff.

Disappearance of pulmonary capillary leak syndrome when i.v. CyA is replaced by oral CyA.

Transplantation 43 (5): 758-759, 1987.

23. G.D.M. Beun, K.M.L. Leunissen, W. Grave, P.J.C. van Breda Vriesman, J.P. van Hooff.

Isolated minimal change nephropathy associated with diclofenac. Br Med J 295: 182-183, 1987.

24. K.M.L. Leunissen, F.T. Bosman, G. Kootstra, J.P. van Hooff. Focal glomerulosclerosis in neonatal kidney grafts.

Lancet il: $1019-1020,1987$. 
25. L. Bouwels, E. Jansen, J.H.A. Janssen, E.C. Cheriex, M. DanielsBosman, K. den Dulk, J.P. van Hooff, K.M.L. Leunissen, H.J.J. Wellens.

successful longterm catheter drainage of purulent pericarditis in an immuno-compromised patient.

Am J Med 83: 581-583, 1987.

26. J.P. van Hooff, K.M.L. Leunissen, P.J. Kingma, A.C. Nieuwenhuyzen Kruseman, C.P. Degenaar, P.P.C.A. Menheere, E.K.M. Beukers, G. Kootstra.

Urine amylase and insulin reserve capacity are valuable tools for diagnosing pancreas allograft rejection.

Transpl Proc XIX (5): 3899-3902, 1987.

27. K.M.L. Leunissen, E.H.J. Heil, J.M.V. Mooy, M.M. Ausens, G. Kootstra, J.P. van Hooff.

Bladder stones as an unusual cause of posttransplant macroscopic hematuria.

Transplantation 44 (4): 582-583, 1987.

28. J.P. van Hooff, P. Bessems, G.H. Beuman, K.M.L. Leunissen.

Absence of allergic reaction to cyclosporin capsules in a patient allergic to standard oral and intravenous solution of cyclosporine.

Lancet ii: 1456, 1987.

29. K.M.L. Leunissen, G. Kootstra, J.M.V. Mooy, P.M. van den Berg-Loonen, J.P. van Hooff.

Plasmapheresis and RATG induced serum sickness.

Clinicad Transplantation 2: 5-8, 1988.

30. K.M.L. Leunissen, J.P. van Hooff.

Acetate or bicarbonate for hemodialysis.

Nephrol Dial Transpl $3(1): 1-7,1988$.

31. J.P. Van Hooff, P. Bessems, G.H. Beuman, K.M.L. Leunissen.

The absence of an allergic reaction to cyclosporine capsules in a patient allergic to standard oral and intravenous solution of cyclosporine.

Transpl Proc XX (2): 640, 1988.

32. K.M. L. Leunissen, F.T. Bosman, G. Kootstra, J.P. van Hooff.

The effect of cyclosporine on renal graft function is dependent on donor age.

Transpl Proc XX (3): 207-208, 1988. 
33. J.P. van Hooff, R.M.L. Leunissen, H.G. Havenith, F.T. Bosman. Cyclosporine and other therapy-resistent mephrotic syndrome. Transpl Proc XX (3): 293-296, 1988.

34. T.L. Kho, G.J.J. Teule, K.M.L. Leunissen, G.A.K. Heidendahl, P.J. Lijnen, A.K. Amery, J.P, van Hooff.

Cyclosporine and urinary prostaglandins. Transpl Proc XX (3): 650-653, 1988.

35. K.M.L. Leunissen, G.H. Beuman, F.T. Bosman, J.P. van Hooff. The nephrotoxic effects of cyclosporine metabolites. Transpl Proc XX (3): 738-739, 1988.

36. K.M.L. Leunissen.

Erythropoietine, de verlossing van de patient met chronische nierinsufficiëntie?

Orgaan voor Dialyse - CAPD en getransplanteerde leden van DVM 1 (3): $10-12,1988$.

37. K.M.L. Leunissen, F.T. Bosman, G. Kootstra, P.M. van den Berg-Loonen, J.P. van Hooff.

Focal glomerulosclerosis in neonatal kidney grafts. Nephron (in press).

38. M.A.M. Vromen, K.M.L. Leunissen, G.G. Persijn, G. Kootstra. Short and long term results with adult non-heart-beating (NHB) donor kidneys.

Transpl Proc (in press).

39. J.H.A. Janssen, J.A. van Engelshoven, E.C. Cheriex, K.M.L. Leunissen.

Chest $X$-ray in chronic dialysis patients: has it any value? Sociedade Radiologia Portoguesa e Medicinia Nuclear (in press).

40. R. Hupperts, K.M.L. Leunissen, T.W.M. van de Wiel, S.J. Hoorntje, J.F. van Hooff.

Uraemic polyneuropathy and kidney transplantation.

Clin Neurol and Neurosurg (in press).

41. J.M.H. Debets, K.M.L. Leunissen, J.P. van Hooff, C.J. van der Linden, W.A. Buurman.

Evidence for involvement of tumour necrosis factor in adverse reactions during therapeutic antibody administration.

Transplantation (in press). 
42. G. Knols, K.M.L. Leunissen, L.J.M. Spaapen, F.T. Bosman, T.W.M. van de Wiel, G. Kootetra, J.P. van Hooff.

Recurrence of nephrocalcinosis after renal transplantation in an adult patient with primary hyperoxaluria type $I$.

Nephrol Dial Transpl (in press).

43. G.J.J. Teule, K.M.L. Leunissen, S. Halders, G. Kemerink, A. van Lingen, G. Kootstra, J.F. van Hooff

Serial radionuclide determinations of graft perfusion in pancreas-spleen transplantation.

Transpl Proc (in press).

44. T.L. Kho, G.J.J. Teule, K.M.L. Leunissen, G.A.K. Heidendal, P.J. Lijnen, A.K. Amery, J.P. van Hooff.

Cyclosporine and urinary prostaglandins.

Transpl Proc (in press).

\section{ABSTRACTS}

1. K.M.L. Leunissen, S.J. Hoorntje, H.A. Fiers, W.T. Dekkers, A.M. Mulder.

Acetate versus bicarbonate dialysis in critically ill patients. A comparative study.

Kidney Int 26: $570,1984$.

2. K.M.L. Leunissen, S.J. Hoorntje, H.A. Fiers, W.T. Dekkers, A.W. Mulder.

The role of acetate in inducing myocardial depression during hemodialysis for acute renal failure.

Kidney Int 27: 705,1985 .

3. K.M.L. Leunissen, F-J.F.E. Vismans, J.P. van Hoof .

Medical treatment of persistent posttransplant hyperparathyroidism with $A P D$.

Kidney Int $28: 243,1985$.

4. K.M.L. Leunissen, J.P. van Hooff.

Cyclosporin and uric acid.

Kidney Int 28: p 397, 1985.

5. K.M.L. Leunissen, R.J.M. van Leendert, F-J.F.E. Vismans, J.P. van Hooff.

Behandlung des nach Transplantation aufgetretenen Hyperparathyreoidismus mit APD.

Nieren- und Hochdruckkrankheiten 9: 418, 1985. 
6. K.M.L. Leunissen, E. Cheriex, J.M.V. Mooy, J.L.J.J. Ralders, J.H.A. Janssen, J.P. van Hooff.

Echocardiografie (M-mode), een belangrijke aanwinst bij het bepalen van een optimal streefgewicht van chronische dialysepatienten.

Proceedings 14 e Dialysedag, 8 maart 1986.

7. K.M.L. Leunissen, R.J.M. van Leendert, F-J.F.E. Vismans, J.P. van Hoofe.

Treatment of posttransplant hyperparathyroidism with APD: a new biophosphonate.

Kidney Int 29 (4): $941,1986$.

8. K.M.L. Leunissen, S.J. Hoorntje, H.A. Fiers, W.T. Dekkers, A.W. Mulder.

De rol van acetaat met betrekking tot de instabiele haemodynamische toestand tijdens henodialyse van patienten met acute nierinsufficiëntie.

NTVG $130(44): 2006,1986$.

9. K.M.L. Leunissen, E.C. Cheriex, J.H.A. Janssen, G.J.J. Teule, J.M.V. Mooy, J.P. van Hooff.

Plasma volume changes during acetate and bicarbonate dialysis and the influence of left ventricular function.

Nephrol Dial Transpl 1 (2): 103, 1986.

10. T.L. Kho, G.J.J. Teule, K.M.L. Leunissen, G.A.K. Heidendah1, P.J. Lijnen, A.K. Amery, J.P. van Hooff.

Nephrotoxic effect of cyclosporin $A$ can be reversed by dopamine. Nephrol Dial Transpl 1 (2): 140, 1986.

11. K.M.L. Leunissen, G.J.J. Teule, T.L. Kho, J.P. van Hooff.

The effect of cyclosporin $A$ on liver perfusion.

Nephrol Dial Transpl 1 (2): 142, 1986.

12. K.M.L. Leunissen, E.C. Cheriex, J.H.A. Janssen, G.J.J. Teule, J.M.V. Mooy, J.P. van Hooff.

plasma volume changes during acetate and bicarbonate dialysis and the influence of left ventricular function.

Ridney Int $30: 635,1986$.

13. R.M.L. Leunissen, S.J. Hoorntje, H.A. Fiers, W.T. Dekkers, A.W. Mulder.

Acetate versus bicarbonate hemodialysis in critically ill patients.

Hospal $12(4): 43,1986$. 
14. K.M. L. Leunissen, M. Ramentol, G. Kootstra, J.P. van Hooff. Donor age: a risk factor for kidney transplantation.

Proceedings 18 th International Course in Transplantation and Clinicall Immunology: p 322, 1986.

15. K.M.L. Leunissen, E.C. Cheriex, J.H.A. Janssen, G.J.J. Teule, J.M.V. Mooy, J.P. van Hooff.

Plasma volume changes during acetate and bicarbonate dialysis and the influence of left ventricular function.

Proceedings Recirculating Bicarbonate Dialysis, 1986.

16. A.W. Mulder, K.M.L. Leunissen, S.J. Hoorntje, H.A. Fiers, W.T. Dekkers.

Hemodynamic aspects in recirculating bicarbonate versus acetate dialysis in patients with acute renal failure.

Proceedings Recirculating Bicarbonate Dialysis, 1986.

17. J.P. van Hooff, K.M.L. Leunissen, F-J.F.E. Vismans, E.K.M. Beukers, P.J. Kingma, C.P. Degenaar, P.J.G. Jörning, G. Kootstra. Control of exocrine secretion in patients with a pancreas allograft.

Digestion $35(1): 57-58,1986$.

18. K.M.L. Leunissen, S.J. Hoorntje, W.T. Dekkers, H.A. Fiers, A.W. Mulder.

Acetate versus bicarbonate hemodialysis in critically ill patients.

Urology Digest, March 1987: p 25-26.

19. K.M.L. Leunissen, E.C. Cheriex, J.H.A. Janssen, G.J.J. Teule, J.M.V. Mooy, J.P. van Hooff.

ultrafiltratie en linker ventrikelfunktie tijdens acetaat- en bicarbonaatdialyse.

proceedings $15 \mathrm{e}$ Dialysedag: p 6,28 maart 1987.

20. J.P. van Hooff, K.M.L. Leunissen, E.K.M. Beukers, A..C. Nieuwenhuyzen Kruseman, P.M. wan den Berg-Loonen, G. Kootstra, P.J.G. Jörning .

Resultaten van pancreastransplantaties in het Akademisch ziekenhuis Maastricht.

Proceedings 15e Dialysedag: p 18, 28 maart 1987. 
21. E.K.M. Beukers, K.M.L. Leunissen, P.P.C.A. Menheere, M. Beintema, P.J.G. Jörning, G. Kootstra, J.P. van Hooff.

Pancreatic transplantation in four patients with type I diabetes mellitus: experience with a new model.

Europ J Clin Invest 17 (2): A26, 1987.

22. G. Kootstra, P.J.G. Jörning, C.J. van der Linden, J.P. van Hooff, K.M.L. Leunissen, E.K.M. Beukers.

Eerste ervaringen met pancreastransplantatie.

NTVG $131(14): 602,1987$.

23. K.M.L. Leunissen, C.P. Degenaar, G.J.J. Teule, T.L. Kho, L.A.M. Frenken, J.P. van Hooff.

Impairment of liver synthetic function and decreased liver flow during CYA therapy .

Neth $J$ Med $30(5): 259,1987$.

24. K.M.L. Leunissen, M. Ramentol, G. Kootstra, F.T. Bosman, J.P. van Hooff.

Donor age: a risk factor for kidney transplantation.

Kidney Int 31 (4): 1047, 1987.

25. J.P. van Hooff, K.M.L. Leunissen, E.K.M. Beukers, P.J. Kingma, P.M. van den Berg-Loonen, C. van der Linden, P.J.G. Jörning, G. Kootstra.

Combined kidney and pancreas transplantation: Early experience. Kidney Int 31 (4): 1050, 1987.

26. P.P.C.A. Menheere, C.P. Degenaar, K.M.L. Leurissen, E.K.M. Beukers, G. Kootstra, J.P. van Hoof

Clinical chemical monitoring of rejection of pancreas allografts. Annals of Clinical Biochenistry 24 (2): 98, 1987.

27. G.J.J. Teule, K.M.I. Leunissen, E.S. van den Linden, J.P. van Hooff, G. Kootstra, G.A.K. Heidendal.

Quantitative assessment of graft perfusion in combined kidney and pancreas-spleen transplantation: a potential application of TCHMPAO.

Nuklear Medizin 26:219-220, 1987.

28. K.M.L. Leunissen, E.C. Cheriex, J.H.A. Janssen, J.M.V. Mooy, J.P. van Hooff.

The vena cava inferior diameter and collapsibility index and the optimal dry weight in chronic hemodialysis patients.

Blood Purification 5: 293-294, 1987. 
29. K.M.L. Leunigsen, E.C. Cheriex, J.H.A. Janssen, J.M.V. MoOY. J.P. van Hooff.

The inferior vena cava dianeter and collapsibility index and the optimal dry weight in chronic hemodialysis patients.

Nephrol Dial Transpl 2 (5): 438, 1987.

30. K.M.L. Leunissen, G. Kootstra, F.T. Bosman, J.P. van Hooff.

The effect of cyclosporin an renal graft function is dependent on donor age.

Nephrol Dial Transpl 2 (5): 465, 1987.

31. K.M.L. Lewisgen, G.J.J. Teule, T.L. Kho, J.P. van Hooff.

Decreased liver flow during CyA therapy.

Proceedings 11. Jahrestagung Gesellschaft für Mikrozirulation: p $221-226,1987$.

32. T.L. Kho, G.J.J. Teule, K.M.L. Leunissen, G.A.K. Heidendahl, P.J. Lijnen, A.K. Amery, J.P. van Hooff.

Cyclosporin and urinary prostaglandins.

Proceedings 11. Jahrestagung Gesellschaft für Mikrozirulation: p $227-232,1987$.

33. K.M.L. Leunissen, G.J.J. Teule, C.P. Degenaar, J.P. van Hooff.

The effect of cyclosporine on liver perfusion and liver synthetic function.

Proceedings Second International Congress on Cyclosporine, 4-7 November 1987 .

34. P.J. Kingma, J.P. van Hooff, K.M.L. Leunissen, P.P.C.A. Merheere, A.C. Nieuwenhuyzen Kruseman, G. Kootstra.

Urine amylase and insulin reserve capacity are valuable tools for diagnosing pancreas allograft rejection.

Proceedings 7th Workshop AIDSPIT Study Group, 31 January 1988.

35. K.M.L. Leunissen, P.P.C.A. Menheere, E.C. Cheriex, B.W. van den Berg, J.P. van Hooff.

Human alpha-natriuretic peptide and the optimal dry weight in chronic dialysis patients.

Nephrol Dial Transpl 3 (4): 542, 1988.

36. K.M.L. Leunigsen, P. Claessens, B.W. van den Berg, J. Kalders, J.P. van Hooff.

Geioniseerd calcium en de regulatile van de bloeddruk tijdens hemodialyse.

Proceedings 16e Dialysedag, 23 april 1988. 
37. J.P. van Hooff, K.M.L. Leunissen, B.W. van den Berg, E.C. Cheriex, D.W. Slaaf, R.S. Reneman.

The influence of fluid removal during hemodialysis on microcirculation.

Int J Microcirc, special issue: s39, August 1988.

38. J.P. van Hooff, K.M.L. Leunissen, B.W. van den Berg, T.C. Noordzij, D.W. Slaaf, R.S. Reneman.

Capillary morphology in chronic hemodialysis patients.

Int $J$ Microcirc, special issue: S126, August 1988.

39. K.M.L. Leunissen, B.W. van den Berg, E.C. Cheriex, R.S. Reneman, D.W. Slaaf, J.P. van Hooff.

The influence of fluid removal during haemodialysis on macro- and skin microcirculation.

Proceedings Prospects and strategies in cardiovascular research, 2-5 October 1988 .

40. K.M.L. Leunissen, P. Claessen, B.W. van den Berg, J. Kalders, J.P. van Hooff.

Ionized plasma calcium plays a pivotal role in controlling blood pressure during haemodialysis.

Proceedings Prospects and strategies in cardiovascular research, 2-5 october 1988 .

41. K.M.L. Leunissen, B.W. van den Berg, J.P. van hooff.

Geioniseerd calcium en de regulatie van de bloeddruk tijdens hemodialyse.

NTvG (in press).

42. J.P. $\operatorname{van}$ Hooff, K.M.L. Leunissen, E.K.M. Beukers, L.A.M. Frenken, P.M. van den Berg-Loonen, C. van der Linden, P.J.G. Jorning, G. Kootstra.

a. Eerste ervaringen met pancreastransplantaties.

NTvG (in press).

b. Pancreas transplantation.

Neth $J$ Med (in press).

43. K.M.L. Leunissen, P. Claessens, B.M. van den Berg, J. Kalders, J.P. van Hooff.

Ionized calcium profile during various bicarbonate dialyses.

Blood Purification (in press).

44. K.M.L. Leunissen, J.P. van Hooff.

Acetate or bicarbonate for hemodialysis.

International Synopses (in press). 